Silviu Miloiu

Editorial Foreword 5

Kari Alenius

A Southeastern "other" with diverse challenges. Romania in Finnish schoolbooks .7

Saulius Kaubrys

Jewish faction at the Third Seimas of Lithuania in 1926-1927: on the way to the identity crisis

Dalia Bukelevičiūtè

European Regional Integration in the Drafting of the Eastern Pact in 19341935: Interests of the Baltic Entente and the Little Entente

Kalervo Hovi

Finland's rapprochement to National-Socialist Germany as reaction against Winter War.

Dragana Kovacevic

Young people from Bosnia and Herzegovina in Norway: Migration, Identity and Ethnicity

Veniamin Ciobanu

International reactions to the Russian suppression of the Polish insurrection (November 1830)

Call for Papers 


\section{Senior Editors:}

Vladimir Jarmolenko, Ambassador, Honorary Chairman of the Romanian Association for Baltic and Nordic Studies

Ion Calafeteanu, Valahia University of Târgoviste

Neagu Udroiu, Ambassador

\section{Editor in Chief:}

Silviu Miloiu, The Romanian Association for Baltic and Nordic Studies

\section{Associate Editors:}

Florin Anghel, Ovidius University of Constanta

Crina Leon, Al.I. Cuza University of Iasi

Bogdan Schipor, "A.D. Xenopol" Institute of History of the Romanian Academy

\section{Editorial Assistant:}

Costel Coroban, "Grigore Gafencu" Research Center for the History of International Relations and Cultural Studies

\section{Editorial Board:}

Mioara Anton, "Nicolae Iorga" Institute of History of the Romanian Academy

Leonidas Donskis, European Parliament

Elena Dragomir, University of Helsinki

Tatiana Dragutan, Maastricht School of Management Romania

Jaroslav Dvorak, Klaipeda University

Raluca Glavan, Mykolas Romeris University of Vilnius

Tuomas Hovi, University of Turku

Saulius Kaubrys, University of Vilnius

Ana-Maria Despa, "Grigore Gafencu" Research Center for the History of International Relations and Cultural Studies

Tiberius Puiu, Romania

\section{International Advisory Board:}

Kari Alenius, University of Oulu Ioan Chiper, "Nicolae Iorga" Institute of History of the Romanian Academy Leonidas Donskis, University of Helsinki Carsten Due-Nielsen, University of Copenhagen

Daina S. Eglitis, The George Washington University

Björn M. Felder, Germany

Marta Grzechnik, University of Greifswald

Rebecca Haynes, University College of London

Kalervo Hovi, University of Turku

Eriks Jekabsons, University of Latvia

Mark Kramer, Harvard University
Ceslovas Laurinavicius, Lithuanian Institute of History

Marko Lehti, University of Turku

Katalin Miklóssy, University of Helsinki

Viatcheslav Morozov, St. Petersburg State University

Valters Šcerbinskis, Riga Stradinš University

David J. Smith, University of Glasgow

Viktor Trasberg, University of Tartu

Sarah Tyacke, International Society of the

History of the Map

Inga Vinogradnaitè, Institute of International Relations and Political Science of Vilnius

University

Luca Zanni, Embassy of Italy in Kyiv

Darius Žiemelis, University of Vilnius

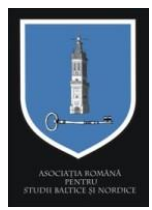

ISSN: 2067-1725

(c) Copyright by Asociația Română pentru Studii Baltice şi Nordice/The Romanian Association for Baltic and Nordic Studies 


\section{Editorial Foreword}

\section{Silviu Miloiu}

President of the Romanian Association for Baltic and Nordic Studies, E-mail: silviu.miloiu@arsbn.ro

Revista Română pentru Studii Baltice şi Nordice / The Romanian Journal of Baltic and Nordic Studies (RRSBN) continues the publication in this issue of a series of studies which have been presented at the annual conference on Baltic and Nordic Studies in Romania. These articles approach topics related to the relations and encounters between Black Sea and the Baltic Sea areas or various developments in the Baltic Sea region during the 20th century. Kari Alenius contributes to this issue with an analysis of the way Romania was presented in the Finnish schoolbooks. As correctly emphasized by the author, this image reflects the perception and attitude of the authors of "the outside world and diversity". Alenius identifies four stages in this respect: end of 1800s until the end of the First World War; early years of the 1920s to the 1950s; the 1960s to the 1980s and the last decades since the 1990s. Although each stage emphasized different characteristics of Romania, the author finds also continues among them.

Saulius Kaubrys deals with the Jewish faction at the Third Seimas of Lithuania in 1926-1927. This was a time when the Jewish faction entered the government. Although it showed solidarity with its coalition partners and hoped that by doing so its aims would be dealt with, the fact that progress in this regard was slow and the coup d'état of December 1926 marked a change of attitude of the Jewish faction from pro-active to passive.

Dalia Bukelevičiūtè approaches the project of the Eastern Pact of 1934-1935 from the perspective of two regional cooperation structures, the Baltic Entente and the Little Entente. The author concludes that in the process of negotiations, it became apparent that countries were more concerned with their narrow national interests than with the common security of the whole bloc.

Kalervo Hovi highlights the rationalities behind Finnish decision to go to war against the Soviet Union alongside, although not in alliance, with Germany. The decision was a result of the way the Finnish elites assessed the national interest in the aftermath of the Winter War. 
Dragana Kovacevic approaches the condition of Bosnians and Herzegovinans residing in Norway who moved to Norway as children and war refugees in the 1990s. It discusses the way they relate to their identity and heritage and also how the receiving society perceives their integration in the Norwegian society. Kovacevic brings into light concepts such as transnational belongings and long-distance nationalism.

An outcome of ample investigations in Sveriges Riksarkivet, Veniamin Ciobanu contributes with new documents revealing the international dimension of the Russian brutal suppression of the Polish insurrection (November 1830). Countries such as Great Britain and France tried to soften the attitude of Russia towards Polish insurgents.

We hope that the variety of themes tackled in this issue and their importance to the enrichment of our knowledge of past and current developments affecting the Black Sea and Baltic Sea areas will foster academic and public debates. 


\title{
SOUTHEASTERN "OTHER" WITH DIVERSE CHALLENGES. ROMANIA IN FINNISH SCHOOLBOOKS
}

\section{Kari Alenius}

University of Oulu, E-Mail: kari.alenius@oulu.fi

\begin{abstract}
:
The purpose of this study is to analyze what sorts of image Finnish schoolbooks have provided of Romania and why this image has been a certain kind. The analysis focuses on the key features of this image and the most pertinent factors that could explain it. It is apparent that the basic nature of this image has largely remained the same from generation to generation. The time period of the study begins with the birth of the modern Finnish school system to the modern day, or from the 1860s to the 2000s. Representations of foreign countries and other cultures in Finnish schoolbooks have been studied to some extent, but the image of Romania as part of this subject matter has so far been unexplored.

The content of Finnish schoolbooks reflects the view of Romania of those who created them, as well as their attitude towards the outside world and diversity. Although there are many permanent elements in these images, there are also changes in emphasis and tone. Based on the changes found in this analysis, development can be divided into four successive stages. The first period includes the last decades of the 1800s until approximately the end of the First World War. The second period extends from the early years of the 1920s to the 1950s. The third period extends from the 1960s to the 1980s and the fourth includes the last two decades.
\end{abstract}

\section{Rezumat:}

Obiectivul acestui studiu este acela de a analiza care a fost imaginea României în manualele ș colare finlandeze $s, i$ ce a generat această imagine. Analiza se concentrează asupra trăsăturilor fundamentale ale acestei imagini ș i asupra celor mai pertinent $i$ factori care o explică. Este evident că elementele de bază ale acestei imagini au rămas în mare parte aceleași de la generație la generație. Perioada de studiu începe de la nașterea sistemului școlar modern din Finlanda până în prezent, sau de la 1860 la 2000. Reprezentările țărilor străine și ale altor culturi în manualele școlare finlandeze au fost studiate într-o oarecare măsură, dar imaginea României, ca parte a acestui subiect, a fost până acum neexplorată.

Conținutul manualelor finlandeze reflectă vederile despre România ale celor care leau creat, precum și atitudinea lor față de străinătate și diversitate. Deși există multe 
elemente permanente în aceste imagini, există, de asemenea, schimbări de accent și ton. Pe baza modificărilor găsite în această analiză, transformările pot fi împărțite in patru etape succesive. Prima perioadă include ultimele decenii ale anilor 1800 până aproximativ la sfârșitul Primului Război Mondial. A doua perioadă se întinde de la începutul anilor 1920 până la 1950. A treia perioadă cuprinde perioada de la 1960 la 1980 și a patra ultimele două decenii.

Keywords: Romania, Finland, stereotypes, imagology, schoolbooks, 20th century

\section{Introduction}

Relations between Finland and Romania are good and interaction in different areas has increased particularly since Romania joined the EU in 2007. In spite of this increase in interaction, absolute figures portraying this cooperation are still relatively low. For example, in the field of foreign commerce, trade from Finland to Romania and in the contrary direction in the last few years has been between 0.2-0.3 percent of the total volume of both countries. In the tourism sector, the situation is similar: a few thousand (tens of thousands at the maximum) Finns visit Romania annually with roughly the same or smaller number of Romanians visiting Finland, which is less than one percent of each country's tourist flow. ${ }^{1}$ In the political and cultural arena, including the scientific community, cooperation is continuous but it affects a relatively small proportion of specialists in all these sectors. For example, the Finnish-Romanian Friendship Association has just over 100 members. This is relatively small a number if it is compared to the corresponding numbers of Hungary, the neighboring country. The membership of the Finnish-Hungarian Friendship Association is approximately $4,300 .^{2}$

\footnotetext{
1 "Maatiedosto Romania. Kahdenväliset suhteet." Suomen suurlähetystö Bukarest, http:/ / www.finland.ro/ public/default.aspx?nodeid=41749\&contentlan=1\&culture=fi-FI (updated 10.11.2011); "Romanian matkailusektori, viime vuosikymmenten kehitys ja tulevaisuuden tavoitteita". Suomen suurlähetystö 30.11.2007, http:/ / www.kauppapolitiikka.fi/public/download.aspx?ID=39533\&GUID=\%7Beb0d3cd179a6-4d2f-be9f-98fc4052becb\%7D (accessed 2.2.2013).

2 Suomi-Romania-Seura ry. Esittely, http://www.srs.suntuubi.com/?cat=12 (accessed 25.2.2013); Suomi-Unkari Seura. Tietoa yhdistyksestä, http://suomiunkari.fi/tietoayhdistyksesta/ (accessed 25.2.2013). 
In the last few years Romania has been featured in the Finnish media due to the Roma who have come to Finland to beg from Romania. The Roma issue has been present particularly in Finnish tabloids, but also more widely in the press, in the context of which Romania has emerged. On the other hand, this theme has appeared in papers fairly rarely and the absolute number of articles has been small. ${ }^{3}$ All in all, it can be estimated that in Finland, Romania is a relatively little-known country. Only a small portion of Finns have a personal experience of Romania, and the material provided by the media has traditionally been very scarce. Therefore, school education is likely the main source by which Finnish have attained material on which to base their views of Romania. School education regarding Romania and other European countries has already from the late 1800s provided all Finns with at least some basic information about European countries and their inhabitants.

Why, then, should the image of Romania presented by Finnish schoolbooks be analyzed, if relations between Finland and Romania have always been rather limited, and neither country has been of significance to the other? In this I am of the same opinion as Vesa Vares, who in 2011 has published an article concerning the perceptions Finnish diplomats regarding Eastern European countries in the interwar period. The fact that prior knowledge of Eastern European countries was relatively scarce and from the Finnish perspective, relevant political or economic interests were not under threat, gave diplomats an exceptionally great amount of freedom to define their position and bring it to light. The images presented by diplomats of their country of station were as a consequence very stereotypical and value laden and at the same time revealing of their general worldview and model of thought. 4

From this perspective, Romania is a good example from which a broader examination of the Eastern European image in Finnish schoolbooks can be begun. Of Eastern European countries, Romania was the largest, most populous, and most diverse in its natural resources. With these features, in

\footnotetext{
${ }^{3}$ Kari Alenius, 'Beggars, scammers, discriminated against by the whole of Europe: Romania's Roma in Finnish tabloids, 2008-2011', The Romanian Journal for Baltic and Nordic Studies, Vol. 4, Issue 2 (2012): 87-109.

4 Vesa Vares, '"Never satisfactory, according to the Finnish standards". From optimism and interest to disappointment and disillusion: Finnish views on the nations in Eastern Central Europe between the world wars', The Romanian Journal for Baltic and Nordic Studies, Vol. 3, Issue 2 (2011): 225-246, here 227-228 in particular.
} 
spite of its distance and obscurity, from the Finnish perspective this was the most important country in its potential along with Poland and Hungary. In Finland, a slightly different perspective of Poland was taken, as Poland was regarded more as a Baltic country (along with Estonia, Latvia and Lithuania) than an actual Eastern European country. Because of its position, Poland had direct security-political significance, which was reflected in different alternatives of alliance particularly during the years 1919-1922. Finland had a special relationship with Hungary because of its linguistic kinship, which increased the value of Hungary in Finnish eyes more than the size and resources of the country would have indicated. ${ }^{5}$

Although the image of Romania portrayed in Finnish schoolbooks has not been examined earlier, the article by Vares mentioned above is worthy of attention when the goal is to examine the perceptions of Finns regarding Eastern European countries. If the conclusion of Vares regarding Romania is summarized in a few key points, Finnish diplomats saw Romania as a corrupt and backward country in which insufficiency and dishonesty prevailed. In comparison to Finland, Romania was strange, different, and inferior, and it did not meet the standards in the eyes of Finnish diplomats of what a developed, modern country should have been. ${ }^{6}$ By analyzing schoolbooks, the extent to which the conceptions of diplomats were similar or different to textbooks written in academic circles becomes clear, as well as how Romania appeared to ordinary Finns reading schoolbooks.

In the case of schoolbooks, Anu Kukkonen's study published in 2003 examining the image of Hungary in Finnish language schoolbooks serves as the best comparison to Romania. ${ }^{7}$ Marco Pribilla's article regarding the image of Hungary in Finnish literature during the interwar period is also notable, and its conclusions are very similar to those of Kukkonen. ${ }^{8}$ To Finns, particularly during the interwar period, Hungary appeared as an admirable kindred country. Public attitudes towards Hungarians and the Hungarian

\footnotetext{
${ }^{5}$ Heikki Roiko-Jokela, "' Reaalipoliittiset edut vaativat rannikkomme eteläpuolelle ystävällismielisen maan". Baltia Suomen lähialuepolitiikassa 1918-1996," in Virallista politiikkaa - epävirallista kanssakäymistä. Suomen ja Viron suhteiden käännekohtia 1860-1991, ed. Heikki Roiko-Jokela (Jyväskylä: Atena Kustannus Oy, 1997), 74-76; Vares 2011: 231-234.

6 Vares 2011: 238-241.

7 Anu Kukkonen, Pustalla ei ole polkua. Unkari-kuva äidinkielen oppikirjoissa (Jyväskylä: Jyväskylän yliopisto, 2003) (unpublished M.A. thesis).

8 Marco Pribilla, 'Window to Horthy's Hungary. Hungary's Political Image in Finnish Literature of the Interwar Period', Valahian Journal of Historical Studies, issue 1 (2004): 7-23. 10
} 
state were completely positive and understanding of the goals of the Hungarian state (for example, in the case repealing the "shameful peace" of Trianon). On the other hand, Vares has found that hidden away from the public, diplomats saw minor things to criticize in Hungarian social life although in their eyes Hungary was a noticeably more positive destination than other Eastern European countries. Undemocratic characteristics were seen in Hungary's politics and Hungarians were regarded as being too impulsive and to some degree foreign in their mentality. ${ }^{9}$ Based on this, a comparison between non-public material and public material is an aspect that should be paid attention to in the analysis.

\section{"Friendly in principle - but also dishonest and inefficient". Romania and the Romanians through Finnish eyes until the First World War}

A permanent feature of Finnish school textbooks from the 1800s to the present has been that the history of Romania has been featured very little. On one hand, the teaching of history has always focused on domestic history, and on the other, on what have been considered the most important world developments and great powers. In European history, emphasis has been put on ancient history and Western European (Great Britain, France and Germany) history. None of these elements have favored Romania. In practice, Romania has only been briefly mentioned in the context of the world wars.

Well over ninety percent of the material in Finnish school books focusing on Romania can be found in geography textbooks, therefore in this study there is reason to focus on analyzing them. Geography textbooks have provided basic information on the natural conditions of each country, as well as the creation of each state. Information on social basics from the 1800s to the present day have consisted largely of four categories: the people (language, ethnic issues), the social system (form of government, governance), culture (religion, customs, mentality), and economy (livelihoods, industries, standard of living).

As the writers of Finnish schoolbooks begun to put Romania onto their "mental map" the first question of principle to be solved was to decide if Romania belonged to the Balkan area or not. The most common

\footnotetext{
${ }^{9}$ Vares 2011: 241-243.
} 
interpretation was that the Danube formed the natural northern border of the Balkan region, in which case Romania was left outside of the Balkans. ${ }^{10}$ However, in a few older books, this interpretation was the opposite. ${ }^{11}$ The national guidelines that were provided by the First National Educational Textbook Committee drawn up in 1899 indirectly referred to the latter interpretation, as Southeast Europe was to be known as "Austria-Hungary" and "the Balkan Peninsula."12 However, the writers of Finnish geography textbooks stuck with the interpretation of geography from the early 1900s that considered natural geography, according to which Romania was not included in the Balkans but it was included as part of "the countries of the Danube in the region," particularly Austria-Hungary.

Romania was therefore not a Balkan country in Finnish schoolbooks, and general descriptions and comments concerning the Balkan area were not directly relevant to Romania. On the other hand, during the whole period under analysis it has been apparent that in schoolbooks, Romania has been portrayed to a great extent in the same way as, for example, the neighboring southern country of Bulgaria or the western country Yugoslavia (or its predecessor and successor, Serbia). At the same time it can be said that in geography textbooks, images of Romania have differed in their portrayal quite significantly from those of Romania's northern neighbor, Hungary. In this case, this difference between Romania and Hungary has been particularly great during the period from the 1920s to the 1950s.

Before the First World War, portrayals of Romania varied in their length from a few lines of text to about two pages. According to the directions given, until the 1980s, geography textbooks, like history textbooks, were recommended or even directed to focus on the most "important" countries in Europe and the world in addition to Finland. In addition, there were directions to place more attention on Finland's

10 J. E. Aro \& J. E. Rosberg, Koulun maantieto (Helsinki: Otava, 1908), 90; O. A. Forsström, Kansakoulun maantieto (Helsinki: Weilin \& Göös, 1901), 124-127; August Kanninen, Kansakoulun maantieto (Tampere: H. T. Bärlund, 1895), 48; Elis Lagerblad, Lärobok i geografi (Borgå: Werner Söderström, 1890), 113.

11 Ed. Erslev, Lärobok i geografin (Wiborg: Clouberg, 1882), 131-135; A. E. Modeen, Oppikirja maantieteessä (Wiipuri: Clouberg ja kump., 1886), 136-141.

12 Suunnitelmia Suomen kansakoulujen Oppi- ja Lukukirjoja varten. Tarkoitusta varten asetetun komitean Mietintö (Raahe: Rob. Rossander, 1899) (hereafter cited as Suunnitelmia 1899), 80. 
neighboring areas than on further countries..$^{13}$ These directions have never favored any focus on Romania.

At the end of the 1800s and beginning of the 1900s the goal of geography education was not only to describe the living conditions around the world, but also to serve as an encouraging example of how, through diligent work and inventiveness, people were able to control nature and survive in a wide range of environments and conditions. ${ }^{14}$ Thus, education served as a general civic education, in which the goal was to create good workers of students who were loyal to their homeland.

Books that depicted Romania most scarcely presented only the location of the country, its area, population, capital city, and some random information such as the mention of agriculture as the main source of livelihood or a short characterization of the natural conditions. ${ }^{15}$ In more extensive works, descriptions were more detailed, although in the 1800s and in the beginning of the 1900s this usually meant an increase in statistics and factual material. Books that took an evaluative stance on Romanian culture, politics and economy consisted of about half of the published textbooks before the interwar period. At the same time, some kind of general assessment as to the degree of development of agricultural and of industry in general was almost always provided. During the 1800s and beginning of the 1900s these general assessments were without exception always slightly negative.

On the basis of geography textbooks, the poor economic situation was caused by three factors. First, serfdom, which was abolished only in 1866, was seen to have hindered development. Serfdom stemmed from what was regarded as very high levels of inequality as peasants lived in poverty and the nobility (bojars) enjoyed an overabundance. The other factor explaining economic misery was a very low level of education. The third factor was the "nature" of the Romanian people. Romanians were seen to be very friendly in principle but at the same time lazy, faint-hearted, and prone to dishonesty. Combining these features with no education resulted in an

\footnotetext{
13 See, for instance Suunnitelmia 1899, 65-76; Peruskoulun opetussuunnitelman perusteet (Helsinki: Kouluhallitus, 1985), 131-143, 165-172.

14 Suunnitelmia 1899, 74.

15 Kanninen 1895, 48-49; Modeen 1886, 137-141.
} 
unambitious approach to work, which did not favor enterprise and efficiency. 16

The portrayal of Romania in schoolbooks largely resembled the way in which the other inhabitants of South and South-Eastern Europe were described. From the perspective of the north, the Mediterranean area and the Balkans were clearly the "Other", to which one's own society was compared and through which a positive identity of one's own group was constructed.17 The writers of Finnish schoolbooks saw their own country as the opposite of that "Other", in which a spirit of enterprise, reasonable discretion, integrity and planning abounded. Combined with the value put on education and a traditionally "free" society and thinking, as a result it produced prosperity, modernity, and rapid development. If on one hand Finland was barren and to some extent even poor in comparison to Scandinavian countries and the leading "Germanic" countries of Western Europe, such as Germany and Great Britain, Finland was nevertheless considered to belong to the same culture as the latter countries. It was desired and thought that the direction of Finland was towards a bright future and a greater similarity to the leading welfare states of the world.

\section{"Romania still undeveloped - but possibly on its way towards a better future". Finnish perceptions of Romania from the 1920s to the 1950s}

The situation described above changed partly during the interwar period. The content of schoolbooks was directed by committee reports during the years 1925, 1933 and 1946, which made recommendations regarding the teaching of all subjects as had occurred in 1899. The basic starting points of the new guidelines were quite similar to those in 1899 . School children were to be brought up in Christianity and moral thought that was based on this. Central in history were "history of the fatherland" and in geography, "geography of the fatherland". 18 Of objectives regarding the presentation of the rest of the world, the guidelines of 1925 stated the

\footnotetext{
16 Aro \& Rosberg 1908, 123-124; Alfred Jotuni, Kansakoulun maantiede (Porvoo: WSOY, 1916), 191; Lagerblad 1890, 114.

17 For similar attitudes in the interwar period, see Vares 2011: 228-229.

18 Maalaiskansakoulun opetussuunnitelma. Komiteamietintö (Helsinki: Valtioneuvosto, 1925), 108113, 140-146; Oppikoulukomitean mietintö (Helsinki: Valtioneuvosto, 1933), 319; Kansakoulun opetussuunnitelmakomitean mietintö I (Helsinki: Valtioneuvosto, 1946), 8. 
following:"...[I]t must be shown how our country offers its own advantages and opportunities, which should not be looked down on alongside the rest of the world, when we are able to use them effectively in the same way as foreigners". ${ }^{19}$ The portrayal of other countries could fulfill these kinds of goals in two ways, by presenting either encouraging or warning examples from the world. In practice, and in geography textbooks as a whole, there was a step towards a more positive portrayal of other cultures and countries.

In the case of Romania as in that of several other European countries, this meant the exclusion of the supposed "national character" of the Romanians and the negative characterizations associated with this. Critical portrayals of the patterns of thought and behavior of nationalities and the innate and unchangeable "racial characteristics" that were thought to underlie them remained only in the descriptions of the peoples of Asia and Africa. In the case of Romania and many other Southern and Eastern European countries, from the 1920s to the 1950s, attention was constantly paid to the low level of education and it was linked to the poor development of the economy. Thus, Romania was seen to be less developed and inferior to Finland. On the other hand, there was a desire to maintain faith in progress and entrepreneurship in students, by describing that Romania had plenty of untapped natural resources and that the possibilities for economic development in the future were good. ${ }^{20}$

If portrayals of Romania are compared to how positively Hungary was presented in schoolbooks from 1920 to 1950, the difference is very noticeable, ${ }^{21}$ although before the First World War the countries had been described in much the same way.22 The essential distinguishing feature was the specific thought attributed to kindred nationalities (in Finnish, heimoaate), which had a powerful influence, particularly among the Finnish nationalist intelligentsia. Almost without exception, the writers of schoolbooks belonged to this group. Finnish independence had elevated the construction

\footnotetext{
19 Maalaiskansakoulun opetussuunnitelma 1925, 52, 149-150.

20 J. E. Aro \& J. E. Rosberg, Koulun maantieto (Helsinki: Otava, 1923), 110-111; Väino Auer \& K. Merikoski, Maantieto (Helsinki: Otava, 1938), 163-166; A. Hakalehto \& A. Salmela, Isänmaa ja maailma (Porvoo: WSOY, 1931), 182; I. Leiviskä, Kansakoulun maantieto I (Helsinki: Maalaiskuntien liitto, 1926), 116-117; Viljo Tolvanen, Kansakoulun maantieto I (Helsinki: Otava, 1927), 151-153.

${ }^{21}$ Aro \& Rosberg 1923, 108-110; Auer \& Merikoski 1938, 160-163; Hakalehto \& Salmela 1931, 177-181; Leiviskä 1926, 114-116; Tolvanen 1927, 150-151.

22 Aro \& Rosberg 1908, 116-119; Jotuni 1916, 96-98; Lagerblad 1890, 112-113.
} 
of a state identity based on Finnish nationalism to the status of a half-official state ideology.23 During the time of Russian rule until 1917 there was not the same kind of opportunity for this. After independence the only significant exceptions were the Swedish-speaking members of the intelligentsia, which a perceived relatedness and solidarity through Finnishness did not concern. It is striking that in Swedish language schoolbooks during the interwar period a targeted admiration of Hungary was absent, ${ }^{24}$ which was predominant and distinct in the image portrayed of Hungary in Finnish language schoolbooks.

Second, if the image given of Romania in schoolbooks is compared to the image that Finnish diplomats inferred of Romania during the interwar period, both similarities and differences can be seen. In both, Romania was socially undeveloped, and in comparison to northern pedantry, disorganization and untidiness prevailed in the country. On the other hand, professionally, diplomats paid a lot of attention to the political culture of their country of station, portraying its numerous faults and the general corruptness of the country. ${ }^{25}$ Such characterizations were lacking completely in schoolbooks. The choice of words in schoolbooks in portraying Romania and other Southern and Eastern European countries was noticeably more neutral than those in diplomatic reports.

The difference was no doubt due to the different uses of the texts and the degree of publicity. In diplomatic reports that were hidden from publicity it was possible to use language that was sharp and the authors of reports were able to present even their most negative thoughts without any particular balance, if they thought the situation warranted this. Schoolbooks were meant for the public in which case there was a lot more to deliberate what at the time was generally considered fit to be said openly. Schoolbooks could be accessed by everyone, even foreign representatives. The most negative diplomatic reports would have likely caused conflicts in foreign policy if they ended up in the public, and schoolbooks could not phrase things as harshly.

In this context it is not possible to determine the extent to which the true views of the writers of schoolbooks were presented in their text. There

\footnotetext{
${ }^{23}$ Kukkonen 2003, 24-50; Pribilla 2004: 21-22.

24 Sigurd Sahlberg, Lärobok i geografi II (Nykarleby: Författarens förlag, 1931), 44-47; Sigurd Sahlberg, Geografi för lärdomsskolor II (Helsingfors: Söderströms, 1944), 100-105.

25 Vares 2011: 231-243. 
was no barrier to presenting a positive impression of foreign countries, as the cases of Hungary and Estonia illustrate. ${ }^{26}$ Instead, the aforementioned limits relating to public discussion and the general guidelines of textbooks limited the presentation of negative views, at least in a very harsh form. Based on this, we can estimate that the perception of Romania and Romanians of the Finnish intelligentsia who contributed to schoolbooks was probably not significantly more positive than what the texts gave to understand. It could have been more negative, but there is insufficient documentary material to examine this matter.

\section{"Progressive Romania". The depiction of socialist Romania during the Cold War and the era of increased cultural tolerance (from the 1960s to the end of the 1980s)}

During the 1960s, there was a significant change in Western European attitudes towards other cultures, at least on a public and educational level. Other cultures began to be interpreted as equal with Western culture, and in school education, for example, instilling understanding and toleration of difference in children became a goal. The content of Finnish schoolbooks was changed in line with these ideals. New national guidelines were drawn up and supplemented several times between the years 1964 and 1985.27 The change had a clear impact on the way Romania was described in Finnish school textbooks from the 1960s to the 1980s. In addition, the political effects of the Cold War were apparent in the content of schoolbooks.

During the Cold War Europe was conceptually split in two, into socialist Eastern Europe and non-socialist Western Europe. In Finnish schoolbooks of geography, Bulgaria, Albania and Yugoslavia, as well as Romania, which was now attached to them, were considered to belong to Southeastern Europe, which was part of Eastern Europe. Similarly, Hungary, Czechoslovakia and Poland, as being more northern socialist countries,

26 Kari Alenius, '"Small nations tied to Russia". Baltic identity conveyed by Finnish schoolbooks from the 1860s to the 2000s', Faravid 36 (2012), 108-110; Kukkonen 2003.

27 Kunnallisten kokeilukoulujen opetussuunnitelmakomitean mietintö (Helsinki: Valtioneuvosto, 1965), 67; Peruskoulun opetussuunnitelmakomitean mietintö II (Helsinki: Valtioneuvosto, 1970), 216; Lukion opetussuunnitelmakomitean mietintö 2 D (Helsinki: Valtioneuvosto, 1977), 828, 840; Peruskoulun opetussuunnitelman perusteet 1985, 170. 
constituted the central part of Eastern Europe, and the Soviet Union (indirectly, though) formed the Northern part in this context.

The educational planning committee report of 1970 which set out broad reforms in education strongly emphasized that in the case of Europe - but quite revealingly no other parts of the world - that "There cannot be any simplified or negative views on any country or people" 28 (italics in original). The emphasis of this perspective was likely related to the political balancing act of the Cold War. The political administration directing school education probably wanted to make sure that schoolbooks should not include anything that could be interpreted as a criticism of socialist ideology or socialist countries, especially the Soviet Union. The Soviet Union was in fact very keen in responding to any "anti-Soviet" phenomena that it interpreted in Finland.29 In principle, these guidelines also prevented the criticism of "capitalist" countries, but criticisms in the direction of the West generally did not result in any foreign policy problems. Therefore, these guidelines must be interpreted as existing to pressure writers to avoid the negative characterization of socialist systems.

The general objective of tolerance as well as political prudence changed the imagery of Finnish schoolbooks in regard to Romania to one that was first neutral ${ }^{30}$ or later positive beginning from the 1960s. The books provided the basics on the economy, culture, and social system of the country without commenting on any problems in any area of life. On the contrary, every now and then the books made reference to the rapid development of the countries and future opportunities. ${ }^{31}$ At the same time, problems in Western Europe were mentioned, such as environmental problems (erosion, pollution), differences in development between the countries, such as the poverty of Portugal and Southern Italy, and even political conflicts (the Basques). ${ }^{32}$ This kind of "one-sided equality" was no doubt the result of the aforementioned political directive.

\footnotetext{
28 Peruskoulun opetussuunnitelmakomitean mietintö 1970, 199.

29 'Juri Derjabin: Puhe Suomen ja Neuvostoliiton ystävyydestä oli liturgiaa', Helsingin Sanomat 28.10.2012.

30 Väinö Auer \& K. Merikoski, Maantieto kansakouluja varten (Helsinki: Otava, 1951), 187-189; Iivari Leiviskä, Koulun maantieto (Porvoo: WSOY, 1956), 163-164.

${ }^{31}$ Harry Krogerus \& Lennart Winqvist, Vår värld åk $5 b$ (Borgå: Söderström et C:o, 1976), 45-49; Jorma Kytömäki et al., Opi maantietoa 5 (Porvoo: WSOY, 1981), 108-109; Matti Leinonen et al., Koulun maantieto 5 (Helsinki: Otava, 1984), 67-69.

32 Kytömäki et al. 1981, 75, 78, 88-90; Leinonen et al. 1984, 96-97, 103, 110. 18
} 
The reorientation in education and politics after the Second World War was apparent, for example, in the geography textbook Opi maantietoa (Learn geography) published in 1981:

Romania is one of the largest producers of corn in Europe. Romania has less concern with energy intake than many other countries. Oil has been drilled near the Carpathian Mountains for decades. In addition to lignite and hard coal, a quite excellent natural gas has been found. Additionally, when Romania has a large number of ores, it is no wonder that it is becoming an industrialized country [--] The capital of the country is Bucharest, with a population of two million. As it is near oil and coal fields as well as some of the best agricultural areas, it has had a good opportunity to develop as a diversified industrial city. ${ }^{33}$

\section{"A Balkan country with various problems". Romania in} Finnish schoolbooks in the post-Cold War era (1990s and 2000s)

In the 1990s and 2000s, the portrayal of Romania in Finnish schoolbooks has been to a considerable extent similar to what it was during the interwar period. Some of the details have been upgraded to reflect the realities of today, but in their tone, the descriptions are clearly different than during the Cold War, when political prudence determined the content of books. Romania is portrayed often in connection with Bulgaria and Moldova. The basic elements of the description are crystallized in few key points, for example as in the geography textbook Avara Eurooppa (Wide Europe) text from 2010:

1) A large portion of Europe's carnivores live in the forests of Romania, Bulgaria and Moldova. 2) Romania, Bulgaria and Moldova are some of the poorest countries in Europe. 3) Poverty has led to corruption and human trafficking. 4) The Roma are the most discriminated minority group. 5) The economies of Romania and Bulgaria develop as a result of tourism and industrial development. ${ }^{34}$

The same things have been essentially repeated in other schoolbooks, thus the picture portrayed of Romania has been predominantly negative.

\footnotetext{
33 Kytömäki et al. 1981, 108-109.

34 Rita Keskitalo et al., Avara Eurooppa (Helsinki: WSOYpro OY, 2010), 102.
} 
The only thing that has been regarded as positive is the development of the economy, albeit from a low starting point. Hindrances to development have often been stated as the "old-fashioned" quality of industry and its largescale serious by-products. ${ }^{35}$ The abundance of large carnivores as mentioned in the Avara Eurooppa text cannot be interpreted as a positive fact, although value in diversity is one of the current goals of school education. The mention of the abundance of beasts (but no other animals) could have strengthened the image of the area as "non-modern" and "wild". The same text published two pictures of Romania, in which one presented a wild stray dog (Fig. 1) and the other the use of Dracula in a restaurant advertisement (Fig. 2). The other two pictures presented an "old-fashioned" countryside (Fig. 3) and a Roma beggar in Finland (Fig. 4). ${ }^{36}$ Thus, the text and images have supported each other in creating a "dangerous", "backwards", and "problematic" impression in the Avara Eurooppa text as well as others in which pictures of Romania have been published. Images became more common in Finnish schoolbooks only from the 1960s, and typically one or two pictures have been published of Romania. Agricultural and industrial facilities have almost always been presented in the pictures, and sometimes individuals dressed in exotic national costumes. ${ }^{37}$

Fig. 1 A wild stray dog in Romania (caricature)

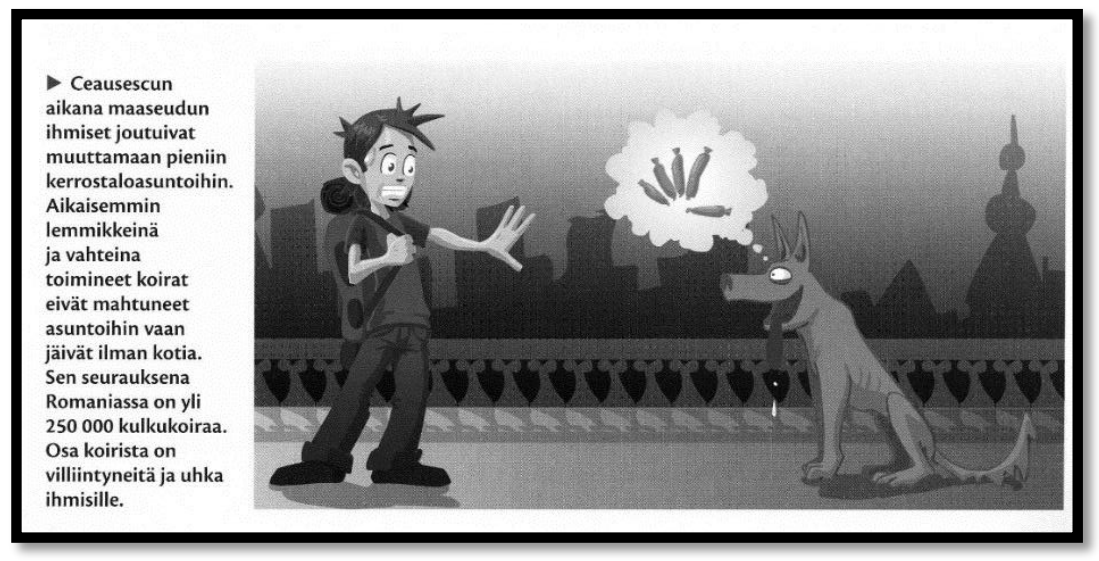

35 Jukka Arohonka et al., Värikäs Eurooppa (Helsinki: WSOY, 1997), 99-102; Hannele Cantell et al., Matkalle Eurooppaan (Helsinki: WSOY, 2002), 137-143; Keskitalo et al. 2010, 98-103; Matti Leinonen et al., KM Eurooppa (Helsinki: Otava 2007), 115-116.

36 Keskitalo et al. 2010, 101-103.

37 Cantell et al. 2002, 142; Krogerus \& Winqvist 1976, 46; Kytömäki et al. 1981, 108-109; Leinonen et al. 1984, 69. 
Fig. 2 Dracula in a restaurant advertisement

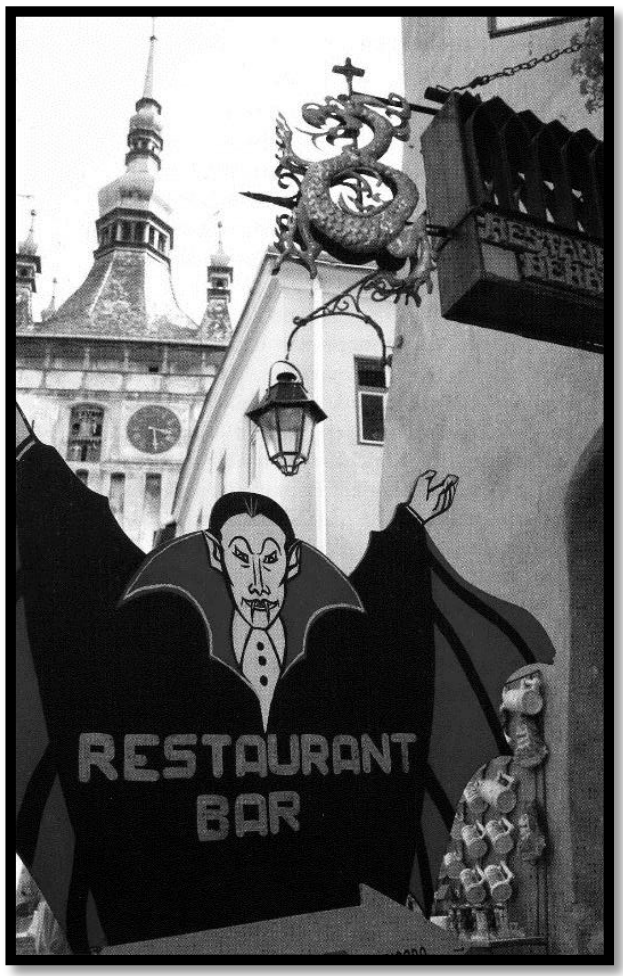

Fig. 3 "Old-fashioned” Romanian countryside

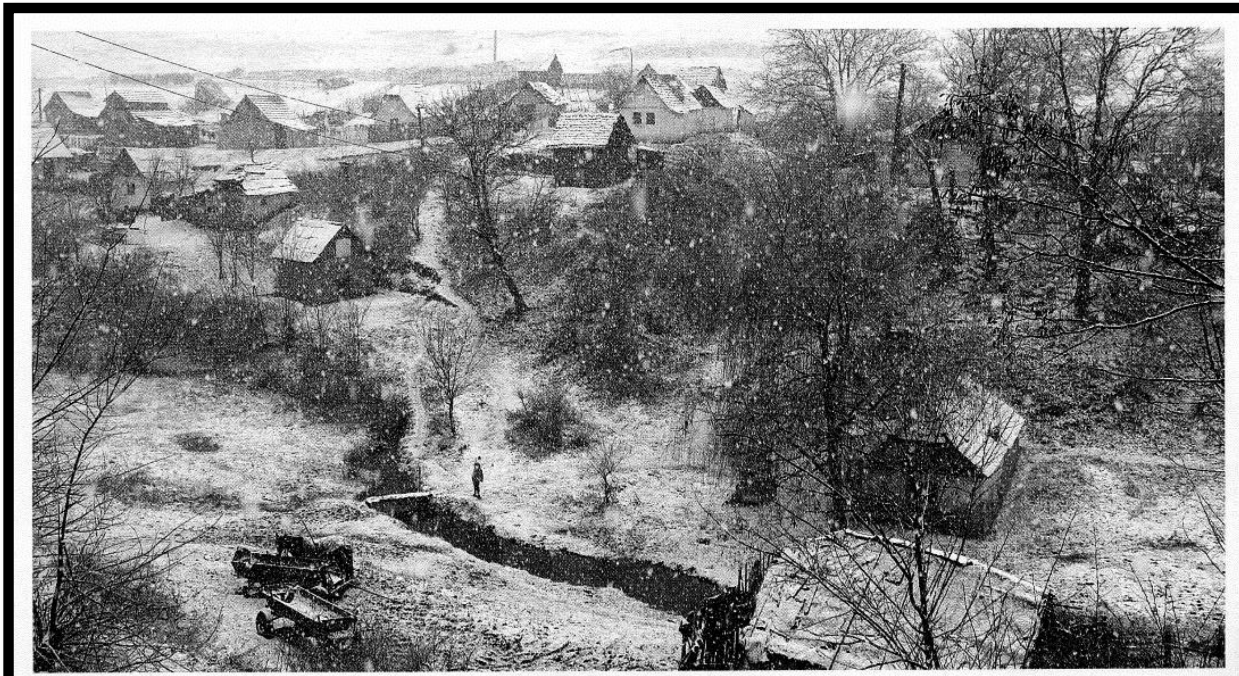

A Romaniasta tuli 2000-luvulla haluttu Hollywood-elokuvien kuvauskohde. Elokuvaohjaajille, jotka haluavat kuvata Amerikan sisällissodan aikaa 1800 -luvun lopulla, maa tarjoaa mainiot puitteet, sillä tämän päivän Romania muistuttaa paljon silloista amerikkalaista maaseutua. 
Fig. 4 A Roma beggar in Finland

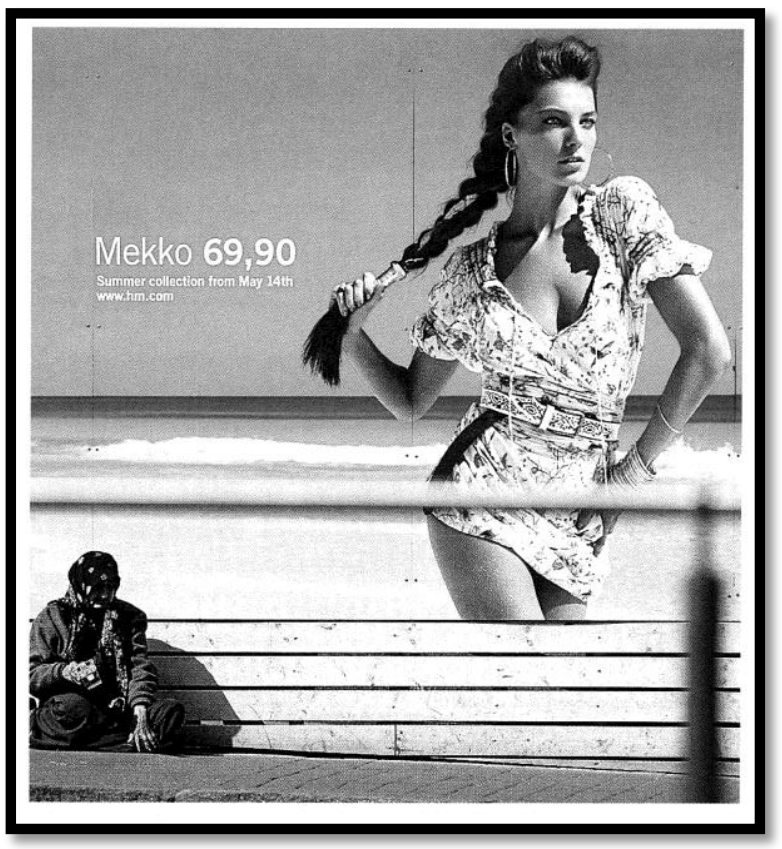

During the last two decades, the showcasing of values based on the United Nations Declaration of Human Rights has gained a strong position in education in Finland and in many other countries. The objective has been that students would be instilled from an early age to actively support internationalization, multiculturalism and the acceptance of diversity. In the case of geography, this has even meant that the special status of one's own country, people and culture has been left out of the curriculum. Instead, emphasis has been put on respecting and appreciating (not only understanding and tolerating) other cultures. ${ }^{38}$ These trends have in principle created favorable conditions in that the positive portrayal of Romania from the 1960s to the 1980s could have strengthened in a still more positive direction.

However, in the case of Southeastern Europe, cosmopolitan ideals have been left in the shade of a strong counterforce. The Yugoslav Wars widely shocked people outside the country, which have again brought to the

\footnotetext{
38 Peruskoulun opetussuunnitelman perusteet (Helsinki: Opetushallitus, 1994), 8-14, 96; Perusopetuksen opetussuunnitelman perusteet (Helsinki: Opetushallitus, 2004), 12, 36-37, 174. 
fore the stereotype of the Balkans as a nest of unrest and violence. ${ }^{39}$ The end of the Cold War has also meant a freed atmosphere of dialogue, including that in schoolbooks. During the 1990s there has been more courage in abandoning a neutral stance towards and discussion of problems in former socialist countries.

In the 1990s and 2000s, the term Balkan has been expanded to include Romania, which has apparently been viewed as being more similar to the Balkan Peninsula than the Central Eastern European countries. The term Balkan has also been used to describe the basic nature of all of the states. The Yugoslav Wars have been called the "Balkan" wars, and all of the states in the region have been referred to as "the Balkans, which have experienced hardship". The latter has referred to the socialist past of the countries, of which the adverse effects have been brought up openly but with exaggeration. For example, the low standard of living and social problems have appeared to be the result of the recent past in schoolbooks. 40

\section{Conclusions}

During the 1990s and 2000s the image of Romania in Finnish schoolbooks has separated substantially from the neutrality of the 1960s to 1980s and begun to resemble that image that was predominant from the 1920 s to 1950 s, or even in the end of the 19th century. A harmful ethnic and cultural diversity, poverty and underdevelopment have been the key elements of the image. The fact that the image portrayed in schoolbooks has been in clear conflict with the formal objectives of education of the late $20^{\text {th }}$ century and the beginning of the $21^{\text {st }}$ century tells much about the strength of old stereotypes. As recent events in the Balkans, particularly the Yugoslav Wars, have created favorable conditions for the rise of old, simplified and largely negative images, this has occurred, although the general guidelines given to textbook writers regarding the portrayal of other states, peoples and cultures has been almost the opposite. Based on schoolbooks at least,

\footnotetext{
39 Cf. Ivana Živančević-Sekeruš, "Balkans," in Imagology. The cultural construction and literary representation of national characters. A critical survey, ed. by Manfred Beller and Joep Leerssen (Amsterdam: Rodopi, 2007), 107.

40 Arohonka et al. 1997, 99-102; Cantell et al. 2002, 137-143; Keskitalo et al. 2010, 98-103; Leinonen et al. 2007, 115-116.
} 
"respect and appreciation" for the special cultural and social features of Romania or the rest Southeastern Europe has not been achieved.

On the other hand, it can be said that Romania has essentially been portrayed in the same way as other Eastern European countries - in neither a significantly negative or positive way. For example, the difference in comparison to Hungary, which was apparent most clearly from the 1920s to the 1950s, almost disappeared during the Cold War, during which the emphasis of the "kindred peoples" idea and the relation between Finland and Hungary was no longer politically trendy. Thus, in Finnish schoolbooks, along with other Eastern European countries, Romania has been seen predominantly as an "Other" to which one's own country can be compared and utilized to construct a positive self-image. It could be that Finns, who have feared that Western Europe will connect them to a "backwards Eastern" reference group, have through time either consciously or unconsciously needed this kind of comparison group. By exaggerating and evaluating existing cultural and social differences, schoolbooks have shown Finns that, in comparison to many other countries, their own country is well developed and its citizenry civilized and otherwise adequate. It has not only improved self-confidence, but provided trust in the future.

\section{References:}

\section{A. Books and articles}

Alenius, Kari. 'Beggars, scammers, discriminated against by the whole of Europe: Romania's Roma in Finnish tabloids, 2008-2011', The Romanian Journal for Baltic and Nordic Studies, Vol. 4, Issue 2 (2012): 87-109.

Alenius, Kari. '"Small nations tied to Russia". Baltic identity conveyed by Finnish schoolbooks from the 1860s to the 2000s', Faravid 36 (2012): 103-118. Aro, J. E. \& Rosberg, J. E. Koulun maantieto. Helsinki: Otava, 1908. Aro, J. E. \& Rosberg, J. E. Koulun maantieto. Helsinki: Otava, 1923. Arohonka, Jukka et al. Värikäs Eurooppa. Helsinki: WSOY, 1997. Auer, Väino \& Merikoski, K. Maantieto. Helsinki: Otava, 1938. Auer, Väinö \& Merikoski, K. Maantieto kansakouluja varten. Helsinki: Otava, 1951.

Cantell, Hannele et al. Matkalle Eurooppaan. Helsinki: WSOY, 2002.

Erslev, Ed. Lärobok i geografin. Wiborg: Clouberg, 1882. 
Forsström, O. A. Kansakoulun maantieto. Helsinki: Weilin \& Göös, 1901. Hakalehto, A. \& Salmela, A. Isänmaa ja maailma. Porvoo: WSOY, 1931. Jotuni, Alfred. Kansakoulun maantiede. Porvoo: WSOY, 1916.

'Juri Derjabin: Puhe Suomen ja Neuvostoliiton ystävyydestä oli liturgiaa.' Helsingin Sanomat 28.10.2012.

Kanninen, August. Kansakoulun maantieto. Tampere: H. T. Bärlund, 1895.

Kansakoulun opetussuunnitelmakomitean mietintö I. Helsinki: Valtioneuvosto, 1946.

Keskitalo, Rita et al. Avara Eurooppa. Helsinki: WSOYpro OY, 2010.

Krogerus, Harry \& Winqvist, Lennart. Vår värld åk $5 b$. Borgå: Söderström et C:o, 1976.

Kukkonen, Anu. Pustalla ei ole polkua. Unkari-kuva äidinkielen oppikirjoissa. Jyväskylä: Jyväskylän yliopisto, 2003 (unpublished M.A. thesis).

Kunnallisten kokeilukoulujen opetussuunnitelmakomitean mietintö. Helsinki: Valtioneuvosto, 1965.

Kytömäki, Jorma et al. Opi maantietoa 5. Porvoo: WSOY, 1981.

Lagerblad, Elis. Lärobok i geografi. Borgå: Werner Söderström, 1890.

Leinonen, Matti et al. KM Eurooppa. Helsinki: Otava 2007.

Leinonen, Matti et al. Koulun maantieto 5. Helsinki: Otava, 1984.

Leiviskä, I. Kansakoulun maantieto I. Helsinki: Maalaiskuntien liitto, 1926.

Leiviskä, Iivari. Koulun maantieto. Porvoo: WSOY, 1956.

Lukion opetussuunnitelmakomitean mietintö 2 D. Helsinki: Valtioneuvosto, 1977.

Maalaiskansakoulun opetussuunnitelma. Komiteamietintö. Helsinki: Valtioneuvosto, 1925.

Modeen, A. E. Oppikirja maantieteessä. Wiipuri: Clouberg ja kump., 1886. Oppikoulukomitean mietintö. Helsinki: Valtioneuvosto, 1933.

Peruskoulun opetussuunnitelmakomitean mietintö II. Helsinki: Valtioneuvosto, 1970.

Peruskoulun opetussuunnitelman perusteet. Helsinki: Kouluhallitus, 1985.

Peruskoulun opetussuunnitelman perusteet. Helsinki: Opetushallitus, 1994.

Perusopetuksen opetussuunnitelman perusteet. Helsinki: Opetushallitus, 2004.

Pribilla, Marco. 'Window to Horthy's Hungary. Hungary's Political Image in Finnish Literature of the Interwar Period', Valahian Journal of Historical Studies, issue 1 (2004).

Roiko-Jokela, Heikki. '"Reaalipoliittiset edut vaativat rannikkomme eteläpuolelle ystävällismielisen maan". Baltia Suomen lähialuepolitiikassa 1918-1996.' In 
Virallista politiikkaa - epävirallista kanssakäymistä. Suomen ja Viron suhteiden käännekohtia 1860-1991. Ed. Heikki Roiko-Jokela. Jyväskylä: Atena Kustannus Oy, 1997.

Sahlberg, Sigurd. Geografi för lärdomsskolor II. Helsingfors: Söderströms, 1944. Sahlberg, Sigurd. Lärobok i geografi II. Nykarleby: Författarens förlag, 1931. Suunnitelmia Suomen kansakoulujen Oppi- ja Lukukirjoja varten. Tarkoitusta varten asetetun komitean Mietintö. Raahe: Rob. Rossander, 1899.

Tolvanen, Viljo. Kansakoulun maantieto I. Helsinki: Otava, 1927.

Vares, Vesa. '"Never satisfactory, according to the Finnish standards". From optimism and interest to disappointment and disillusion: Finnish views on the nations in Eastern Central Europe between the world wars.' The Romanian Journal for Baltic and Nordic Studies, Vol. 3, Issue 2 (2011).

Živančević-Sekeruš, Ivana. 'Balkans.' In Imagology. The cultural construction and literary representation of national characters. A critical survey. Ed. by Manfred Beller and Joep Leerssen. Amsterdam: Rodopi, 2007.

\section{B. Web postings}

"Maatiedosto Romania. Kahdenväliset suhteet." Suomen suurlähetystö Bukarest,

http:/ / www.finland.ro/public/ default.aspx?nodeid=41749\&contentlan=1 \&culture=fi-FI, updated in 10.11.2011

"Romanian matkailusektori, viime vuosikymmenten kehitys ja tulevaisuuden tavoitteita". Suomen suurlähetystö 30.11.2007, http:/ / www.kauppapolitiikka.fi/public/download.aspx?ID=39533\&GUID $=\% 7 B e b 0 d 3 c d 1-79 a 6-4 d 2 f-b e 9 f-98 f c 4052 b e c b \% 7 D$, accessed at 02.02.2013 Suomi-Romania-Seura ry. Esittely, http:/ / www.srs.suntuubi.com/?cat=12, accessed at 25.02.2013

Suomi-Unkari Seura. Tietoa yhdistyksestä, http://suomiunkari.fi/tietoayhdistyksesta/, accessed at 25.02.2013 


\title{
TEWISH FACTION AT THE THIRD SEIMAS OF LITHUANIA IN 1926-1927: ON THE WAY TO THE IDENTITY CRISIS
}

\section{Saulius Kaubrys}

Vilnius University, E-mail: saulius.kaubrys@if.vu.lt

\begin{abstract}
:
The article discusses the characterisation of the activity of the Jewish faction before the third Seimas and its actions at the short-lived Third Seimas. Due to the circumstances that formed at the Constituent Seimas, the Jewish faction belonged to the Seimas opposition at the First and Second Seimas. The results of the election to the Third Seimas in 1926 provided the Jewish faction with the opportunity to become a constituent part of the ruling coalition. The requirements imposed on the large partners of the coalition reflected both the aspiration to correct "the mistakes" made by the former Seimas with respect to the Jewish community and the aspiration to form the perspective of new possibilities. The relationships with the coalition partners went through two different phases - until the coup d'état of December 1926 and after it. The former link of solidarity and loyalty was replaced with a collective behaviour of adaptation, which permeated the actions of the factions of other ethnic minorities. Work experience in solving the Jewish problems at the Third Seimas is not wide and long.
\end{abstract}

\section{Rezumat:}

Articolul realizează o caracterizare a activității grupării evreiești înainte de a treia Seimas și din cursul scurtei activități a acesteia. Datorită circumstanțelor care au condus la Seimas constituantă, gruparea evreiasă făcuse parte din opoziție in cadrul primelor două Seimas. Rezultatul alegerilor pentru a treia Seimas din 1926 a oferit grupării evreiești șansa de a deveni o parte componentă a coaliției conducătoare. Cerințele impuse partenerilor mai mari din coaliție au reflectat atât aspirația de a corecta "greșelile" realizate de anterioarele Seimas cu privire la comunitatea evreiască, cât și pe aceea de a deschide perspectiva unor noi posibilități. Relația cu partenerii de coaliție a trecut prin două etape distincte - până la lovitura de stat din decembrie 1926 și după aceea. Fosta legătură de solidaritate și loialitate a fost inlocuită cu un comportament colectiv de adaptare, care a impregnat acțiunile grupărilor altor minorități etnice. Activitatea depusă pentru rezolvarea problemelor evreiești în cadrul celei de-a treia Seimas nu este consistentă și nici de durată. 
Keywords: Third Seimas, Jewish faction, elections, Peasant Popular Union, Social Democrats

\section{The Jewish faction at the Lithuanian Seimas in 1920-1926: on the margin of political opposition}

The Independence of Lithuania declared in 1918 opened up new possibilities for society and its self-expression. The characterisations of the election campaign to the Seimas of Lithuania and the activity of the members elected to them became examples of the political school of society - both of the prevailing majority of the Lithuanians and of the ethnic groups. Thirty one lists of candidates, including 5 lists of the representatives of the ethnic groups, were nominated in six constituencies in the election to the Constituent Seimas on 14-16 April 1920. The only list of the Jewish candidates - the Jewish People's Unification received 44709 votes of the electors, which accounted for $52.74 \%$ of all the votes received by the lists of the ethnic groups. Six persons of Jewish nationality were elected to the Constituent Seimas - Ozer Finkelshtein, Naftl Fridman, Avrom Popel, Nachman Rachmilevich, Šimšn Rozenbaum and Maks Soloveichik.

During the election to the First Seimas that took place at the end of 1922, 13 lists of the ethnic minorities were nominated, including 3 lists of the Jews. The Jewish people's party Achdus received 16841 votes, the Zionist group For the Nation and Autonomy was given 34697 votes and the Committee of Jewish People gained 3619 votes. The election was held in accordance with the new regulation approved by the Law on Elections of the Seimas on 19 July 1922, which was partly unfavourable to the lists of the "minorities". Only three Jewish candidates were elected to the first Seimas -- Lev Garfunkel, Joel Bruck, and Josel Berger.

In the elections to the Second Seimas held on May 12-13 1923, eight lists of the candidates of the ethnic minorities, including two "purely" Jewish lists were submitted (the Jewish People's Party Achdus received only 53 votes, the list of the Jewish workers obtained 1048 votes). Nonetheless, the joint list of the United Minorities (Jews, Germans, Russians, and Byelorussians) enjoyed the greatest success, it obtained as many as 99379 electors' votes. Seven Jewish representatives were elected to the second Seimas - O. Finkelshtein, L. Garfunkel, Yosef Kaganeman, Jacob Robinzon, Josel Roginski, S. Rozenbaum, and Sulim Volf). 
The results of the elections to the Seimas (the Constituent Seimas, the first and the Second Seimas) testify to the fact that the Jewish representatives outnumbered the representatives of other ethnic groups (see Table No. 1).

Table No.1. Representatives of national minorities in Lithuanian Seimas (1920-1926).

\begin{tabular}{|l|c|c|c|c|c|}
\hline \multicolumn{1}{|c|}{$\begin{array}{c}\text { Title of } \\
\text { Seimas }\end{array}$} & $\begin{array}{c}\text { Elected in } \\
\text { total }\end{array}$ & Jewish & Polish & Russian & German \\
\hline $\begin{array}{l}\text { Consistuent } \\
\text { Seimas }\end{array}$ & 112 & 6 & 3 & - & 1 \\
\hline First Seimas & 78 & 3 & 2 & - & - \\
\hline Second Seimas & 78 & 7 & 4 & 1 & 2 \\
\hline
\end{tabular}

The Lithuanian historian Arkadijus Bliuminas, having studied the characteristics of the activity of the Jewish faction, stated that the course followed by the Jewish faction at the Constituent Seimas was referred to as sustaining-creating, as stagnating in the First Seimas and as protectingdefending in the second Seimas ${ }^{1}$. The model of the political course of the Jewish faction offered by the said author most probably should be corrected. For example, it is hardly possible to refer to the activity of the Jewish representatives in the First Seimas as stagnant, all the more so that the latter Seimas functioned only for several months and none of the factions had time to accomplish anything particular.

The quantitative and qualitative analysis of the utterances of the members of the Jewish faction in the Seimas leads us to the following supposition:

1) The Jewish representatives were not just passive observers though restricted by objective circumstances (belonging to the minority of the Seimas), within the bounds of possibility, they sought to ensure more favourable conditions for the development of the Jewish community. The rostrum of the Seimas became the place of publicising their interests. The Jewish politicians were made to manoeuvre and form a coalition now with the right-wing parties now with the left-wing ones². According to the interwar leading figure in law Mykolas Riomeris, the Jews in the Constituent

\footnotetext{
1 Arkadijus Bliuminas, Žydu frakcija Lietuvos Seimuose 1920-1927 m. (Vilnius, 2003), 68.

2 Vladas Sirutavičius, "Valdžios politika žydų atžvilgiu", in Lietuvos žydai. Istorinè studija, eds. Vladas Sirutavičius, Darius Staliūnas, Jurgita Šiaučiūnaitė-Verbickienė (Vilnius, 2012), 306.
} 
Seimas "most often adhered to the populists [Peasant Popular Union - S.K.] and were inclined to support them in the state employment" 3 .

2) The Jewish faction most likely also had to admit that their representation was partly inefficient. For example, during the entire term of office of the Constituent Seimas (1920-1922 m.) O. Finkelshtein "did not speak in public from the Seimas rostrum. He personally, or together with members of other factions, submitted interpellations to the highest public authorities to which they received answers but they did not become amendments to the laws to be considered" 4 . N. Fridman, in the Commission on the Land Reform of the same Seimas, "defended the rights that belonged to the Jews to land, however, the attempts to legalise all hat were fruitless" During the whole period of work of the Constituent Seimas a member of the Jewish faction N. Rachmilevich "submitted 30 amendments, proposals, editorial remarks, but their absolute majority was rejected $<\ldots>^{\prime \prime} 6$.

3) The Jewish faction underwent the fate of unfavourable decisions related to the development of the Jewish community in the same way (for example, on 3 September 1924, Second Seimas of Lithuania issued a resolution according to which shops had to be closed on Sundays and during Catholic festivals, in 1925, the spread of the Jewish national autonomy was suspended) 7 . Most probably there was not always unity inside the Jewish faction itself (for example, there were disagreements about the proposals in the draft of the Constitution) $)^{8}$.

\section{Election to the Third Seimas and becoming a partner in the ruling political coalition}

The election to the Seimas that took place on 8-10 May 1926 reflected the moods of the society that was disappointed with the policy of the Christian Democratic bloc and, most probably, its greater disunity. For example, 31 lists were nominated in the election to the Constituent Seimas,

\footnotetext{
${ }^{3}$ Mykolas Rėmeris, Lietuvos konstitucinès teisés paskaitos (Vilnius, 1990), 139.

4 Eglè Bendikaitè, "Finkelšteinas Ozeris", in Lietuvos Steigiamojo Seimo (1920-1922 metu) nariu biografinis žodynas (Vilnius, 2006), 141-142.

5 Bendikaitè, "Fridmanas Naftalis", Lietuvos Steigiamojo Seimo, 144.

${ }^{6}$ Bendikaitė Eglè, "Rachmilevičius Nachmanas", Lietuvos Steigiamojo Seimo, 293.

${ }^{7}$ Liudas Truska, Vareikis Vygantas, Holokausto prielaidos. Antisemitizmas Lietuvoje XIX a. antroji pusé - 1941 m. birželis (Vilnius, 2004), 50; S. Atamukas, Lietuvos žydu kelias nuo XIV amžiaus iki XX a. pabaigos (Vilnius, 1998), 130.

8 See: "Žydų bendruomenių organizavimo klausimai", Savivaldybè 1 (1926): 17. 30
} 
and 55 lists of candidates were nominated in the election to the Third Seimas 9 . The Jewish community chose from two lists: the United democratic and Religious-economic ones (Achdut and others) ${ }^{10}$.

Active propaganda-preparatory work was carried out. For example, on 18 April 1926, a meeting of the Jewish residents inspired by the representatives of the list of the Jewish Democratic Unification took place in Panevėžys. During the meeting, which was attended by approximately 600 people, the member of the Seimas O. Finkelshtein took the floor and spoke about the future election and the tasks of the Jewish community ${ }^{11}$. On 30 April 1926, a pre-election meeting of the Jews took place again in Panevéžys in which the member of the Seimas J. Robinzon participated ${ }^{12}$.

Nevertheless, it seems that the election to the Third Seimas dispelled the myth that was created in society about the seeming unity of the Jews ${ }^{13}$. The Jewish Democratic Unification received 47142 votes, the economicreligious list of the Jews obtained 16702 votes $^{14}$. The Jewish representatives received only three seats in the Seimas - O. Finkelshtein, L. Garfunkel and J. Robinzon became parliamentarians.

The results of the election to the Third Seimas testified to a change in the public opinion - disappointment with the former policy of the Christian Democratic bloc of 1923-1926 and a more obvious support of the left-wing parties - the Social Democrats and the Peasant Popular Union. Having received the largest number of votes (22), the latter undertook the initiative to form the ruling coalition, which under the circumstances of that time was impossible without the Social Democrats and the third party - the participation of the representatives of ethnic minorities. Most likely this choice was determined by both the similarity of ideological positions and practical aspects of the formation of the coalition (there was no possibility of a wider choice). A coalition agreement between the large partners - the

\footnotetext{
9 Vytautas Andriulis, Mindaugas Maksimaitis, Vytautas Pakalniškis, Justinas Sigitas Pečkaitis, Antanas Šenavičius, Lietuvos teisés istorija (Vilnius, 2002), 342.

10 Bliuminas, 58; Liekis Šarūnas, A State within a State? Jewish autonomy in Lithuania 1918-1925 (Vilnius, 2003), 201.

11 Report of the Governor of the town and district of Panevėžys of 19 April 1926 to the Department of Citizens Protection, Lithuanian Central State Archives, Fund 404, Inv.1, file $263,1125$.

12 Report of the Governor of the town and district of Panevezzys of 9 May 1926 to the Department of Citizens Protection, ibid., 1. 157.

${ }^{13}$ Liudas Truska, Lietuviai ir žydai nuo XIX a. pabaigos iki 1941 m. birželio (Vilnius, 2005), 75.

${ }^{14}$ Lietuvos statistikos metraštis 1924-1926, vol. 1, 84-89.
} 
Lithuanian Peasant Popular Union and the Lithuanian Social Democratic Party seems to have not been properly balanced - the members of the Peasant Popular Union most likely had gone to too great compromises and failed to foresee their possible consequences ${ }^{15}$.

The minor partners in the future coalition - the representatives of ethnic minorities, including the representatives of the Jews, formulated their requirements. The analysis of the proposal package made by the Jews leads us to the following supposition:

1) it contained the requirements of three types: in "the sphere of the national rights", "in the sphere of the general civil rights" and "in the sphere of economic issues". The perspective of their implementation from the point of view of time is divided into the "near ("urgent", "in the first session") and the "distant" ones ("with the passing of time", "after the first session"). According to the manner of their implementation, two possibilities of their realisation are provided for - "by way of giving the law" and "administratively".

2) the contents of the requirements reflected the aspirations of the Jewish faction: a) reconstructive aspirations (e.g., to abolish the Law on Jewish National Communities"); b) the continuous aspirations ("a loyal fulfilment of the promises given [...] to the League of Nations on 12 May 1922); c) the aspirations ensuring a positive development of the Jewish community (e.g. an increase in the subsidies granted to the Jewish secondary schools and others). Some of the latter requirements were rather petty (for example, solving "the issue of Kaunas slaughter house", "free admission of the Jews to the civil service").

The requirements of the Jewish faction concerning the issue of education submitted to the Lithuanian Social Democratic faction urged the authorities to recognise the dismissals of the teachers on account of a lack of qualification as unlawful. It was required to increase subsidies to secondary schools, to allow foreign teachers enter Lithuania, to invite a professor to the University to teach a course in Jewish studies, etc. The answer of 12 June 1926 to the Jewish faction stated that the majority of the requirements would be fulfilled, whereas others were left open (for example, the University, as an

\footnotetext{
15 Mindaugas Tamošaitis, „III Seimas (1926-1927)“, in Lietuvos Respublikos Seimu I (1922-1923), II (1923-1926), III (1926-1927), IV (1936-1940) nariu biografinis žodynas (Vilnius, 2007), 140. 32
} 
autonomous institution, had an exceptional status, and it was impossible to get round this institution directly).

It seems that the package in the form of the requirements concerning educational issues was the most acceptable to both largest partners. The Chairman of the Peasant Popular Union faction Zigmas Toliušis stated later at a general meeting of the representatives of the party held on 6-8 December 1926 that he had found it easiest to come to an agreement with the Jews because "there is no need to interfere with their cultural life (there was no hope of Lithuanianising them) and the faction gave them freedom in cultural and religious things. No attempts were made to come to an agreement on the economic matters altogether since they represented merchants, the faction was a supporter of co-operative societies"16. The Lithuanian Peasant Popular Union faction had also promised to go through the Law on Education again because it was not only the Jews who demanded that - there were more similar requests in society.

It is thought that both the large and the minor partners in the coalition (the Jews belonged to the latter) needed one another. If the former had no other possibility of choice, the "minor" ones (Jews, Germans, Poles) had a historical chance to be in political power.

\section{Test by power and durability of the coalition}

During the term of office of the Third Seimas 78 sittings took place. Members of the Jewish faction took the floor 15 times (O. Finkelshtein - 7, J. Robinzon - 5, L. Garfunkel - 3 (see Table No.2).

Table No.2. Speeches of the representatives of Jewish faction, 1926.

\begin{tabular}{|l|l|c|}
\hline \multicolumn{1}{|c|}{ Data } & \multicolumn{1}{|c|}{ Title } & Speaker \\
\hline 2 June, 1926 & $\begin{array}{l}\text { Speech of the Chairman of the } \\
\text { Century }\end{array}$ & O. Finkelštein \\
\hline 9 June, 1926 & $\begin{array}{l}\text { Report of the Commission on } \\
\text { Commissions }\end{array}$ & O. Finkelštein \\
\hline 22 June, 1926 & Draft Law on Amnesty's & O. Finkelštein \\
\hline
\end{tabular}

\footnotetext{
16 Minutes of the Meeting of the representatives of the Lithuanian Peasant Popular Union of 6-8 December 1926, Wroblewski Library of the Lithuanian Academy of Sciences, Manuscript Department, F. 199-41, 1. 82-83.
} 


\begin{tabular}{|c|c|c|}
\hline 23-24 June, 1926 & $\begin{array}{l}\text { Discussions about the declaration of } \\
\text { the Cabinet of Ministers }\end{array}$ & J. Robinzon \\
\hline 2 July, 1926 & Draft Law on Amnesty's & O. Finkelštein \\
\hline 2 July, 1926 & Draft Law on Amnesty's & J. Robinzon \\
\hline 18 July, 1926 & $\begin{array}{l}\text { Interpellation concerning the financial } \\
\text { policy of the Cabinet of Ministers }\end{array}$ & L. Garfunkel \\
\hline 5 October, 1926 & $\begin{array}{l}\text { On Amending the Law on the Patient } \\
\text { Account }\end{array}$ & O. Finkelštein \\
\hline $\begin{array}{l}5 \text { November, } \\
1926\end{array}$ & $\begin{array}{l}\text { Change in the staff of the Ministry of } \\
\text { the Interior }\end{array}$ & O. Finkelštein \\
\hline $\begin{array}{l}12 \text { November, } \\
1926\end{array}$ & Law on the State Budget & L. Garfunkel \\
\hline $\begin{array}{ll}2 & \text { December, } \\
1926 & \end{array}$ & $\begin{array}{l}\text { The State Budget of the Republic of } \\
\text { Lithuania of } 1927\end{array}$ & O. Finkelštein \\
\hline $\begin{array}{ll}10 & \text { December, } \\
1926 & \end{array}$ & $\begin{array}{l}\text { Amendment to the Law on Public } \\
\text { Holidays and Rest }\end{array}$ & L. Garfunkel \\
\hline $\begin{array}{ll}14 & \text { December, } \\
1926 & \end{array}$ & $\begin{array}{l}\text { The State Budget of the Republic of } \\
\text { Lithuania of } 1927\end{array}$ & J. Robinzon \\
\hline $\begin{array}{ll}30 & \text { December, } \\
1926 & \\
\end{array}$ & $\begin{array}{l}\text { The State Budget of the Republic of } \\
\text { Lithuania of } 1927\end{array}$ & J. Robinzon \\
\hline $\begin{array}{ll}31 & \text { December, } \\
1926 & \end{array}$ & $\begin{array}{l}\text { The State Budget of the Republic of } \\
\text { Lithuania of } 1927\end{array}$ & J. Robinzon \\
\hline
\end{tabular}

Due to natural reasons the routine practice of the short-lived Third Seimas was not "saturated" with the issues of the Jewish problems. Nevertheless, the contextual creation of laws provided the Jewish faction with chances to publicise general interests of its electorate. This possibility perhaps presented itself most clearly when the amendments to the Law on Public Holidays and Rest was considered (the Law adopted at the Second Seimas established practice of possible working days that was unfavourable to the Jews). The contents of the motifs concerning the Law presented by L. Garfunkel was discussed at the sitting held on 10 December 1926 both disagreeing to its essence ("here we should not think that having amended that Law our economic situation will improve", Antanas Šmulkštys) ${ }^{17}$, and not recognising the importance of the proposals put forward ("merchants

17 The 57th sitting of 10 December 1926, Records of the Third Seimas 1926-1927 (Kaunas, 1927), 13. 34 
Jews who find this law especially uncomfortable do not constitute a larger part of society" Petras Radzevičius) ${ }^{18}$, and also indiscreetly seeing personal reasons ("small merchants are abolishing and Mr. Garfunkel and Mr. Finkelshtein are supporting that draft law" Antanas Endziulaitis) ${ }^{19}$. Nonetheless, a relative victory was won - the law was recognised as worth being considered. At the sitting held on 12 November 1926, when considering the draft law on the State Budget, L. Garfunkel appealed to the cause that determined the abolishment of the Jewish national autonomy in 1924, when the laws of the office of the Minister for Jewish Affairs were still in effect no funds were allocated to that institution ${ }^{20}$. Thereby, given the example of the dichotomy of the operation of that law and its implementation the authorities were urged to avoid similar mistakes in the future.

The actions of the Jewish faction as an ally of the large partners of the coalition, which was linked by internal obligations, are to be assessed from several perspectives. First, as the actions of loyal associates. For example, at the sitting held on 23-24 June 1926 the Jewish faction expressed confidence in the Cabinet of Ministers'1; at the sitting held on 5 November 1926, the Jewish representatives voted unanimously for the ratification of the agreement between the Republic of Lithuania and the USSR 22 ; at the sitting of 3 December 1926 they supported the formula for the answer to the interpellation put forward by Pranas Dailide (the Peasant Popular Faction), Kipras Bielinis (the Social Democratic Faction) and J. Robinzon that was related to the demonstration in Kaunas on 21 November $1926^{23}$. Second, as non-solidarity actions. For example, at the meeting held on 21 July 1926, when the draft of the Peasant Popular Faction on supplementing and amending the estimate of the state expenditures was discussed (concerning the funds allocated to the clergy for the services of registration of marriages). The Seimas disapproved of the latter proposal. It seems that the Jewish representatives were among those who disapproved of $i^{24}$. Nonetheless,

\footnotetext{
18 Ibid, 5.

19 Ibid., 10.

20 The 42nd sitting of 12 November 1926, Records of the Third Seimas 1926-1927 (Kaunas, 1927), 1819.

21 The 12th sitting of 23-24 June 1926, ibid., 30-31.

22 The 40th sitting of 5 November 1926, ibid., 31.

23 The 53rd sitting of 3 December 1926, ibid., 27.

24 The 25th sitting of 21 July 1926, ibid., 43; Tamošaitis, 158.
} 
there were more manifestations of non-solidarity after the coup d'état of 17 December 1926. For example, at the sitting of 31 December 1926, when considering the 1927 budget, the representatives of the Social Democrats and the Peasant Popular Union said that they were going to vote in favour of, whereas the Jewish representatives (as well as those of the Poles and Germans) said they would abstain ${ }^{25}$. In 1927, at the remaining sitting of the Seimas (on 12 April the Seimas was dissolved) the representatives of the Jewish faction did not speak at all and did not express any support of the partners in the former coalition - for example, when considering the declaration of the new Cabinet of Ministers on 3 March 1927 and on 8 March 1927 too. It is true, Rudolf Kinder, when speaking at that sitting on behalf of the minority factions announced that they were not going to take part in the confidence vote for the Cabinet of Ministers. It is thought that such a passive attitude of the Jews (like that of the representatives of other minority groups) cannot be assessed as integral.

\section{Conclusions}

The results of the election to the Third Seimas provided the Jewish faction with the historical chance to become a constituent part of the ruling political coalition. The package of the requirements to the future partners in the coalition was partly rational inspired from the programme of this minority, however, failing to avoid certain worthless stuff and "dirt". The presence of the representatives of the Jewish faction in the coalition is characterised by two different forms of collective behaviour - relatively active and passive. The sequence of events that formed in the course of the 1926 coup d'etat became the dividing line. The routine practice of the Seimas legislation, due to both its transience and the priorities of solving general state topical issues gave few chances to publicising and defending the Jewish problems. The reserved position of the Jewish faction with respect to the former larger partners in the coalition in 1927 most probably was a joint coordinated attitude of the factions of ethnic minorities, which can be treated as partly inconsistent.

25 The 67th sitting of 31 December 1926, Records of the Third Seimas 1926-1927, 16. 


\section{References:}

\section{A. Archives:}

Lithuanian Central State Archives, Fund 404, Inv.1, file.263.

\section{B. Books and articles:}

"Žydų bendruomenių organizavimo klausimai". Savivaldybe 1 (1926). Andriulis, Vytautas, Mindaugas Maksimaitis, Vytautas Pakalniškis, Justinas Sigitas Pečkaitis, Antanas Šenavičius. Lietuvos teisès istorija. Vilnius, 2002.

Atamukas S. Lietuvos žydų kelias nuo XIV amžiaus iki XX a. Pabaigos. Vilnius, 1998.

Bliuminas, Arkadijus. Žydu frakcija Lietuvos Seimuose 1920-1927 m. Vilnius, 2003.

Liekis Šarūnas. A State within a State? Jewish autonomy in Lithuania 1918-1925. Vilnius, 2003.

Lietuvos Respublikos Seimu I (1922-1923), II (1923-1926), III (1926-1927), IV (1936-1940) narių biografinis žodynas. Vilnius, 2007.

Lietuvos statistikos metraštis 1924-1926, vol. 1.

Lietuvos Steigiamojo Seimo (1920-1922 metu) nariu biografinis žodynas. Vilnius, 2006.

Rėmeris, Mykolas. Lietuvos konstitucinès teisés paskaitos. Vilnius, 1990.

Sirutavičius, Vladas. „Valdžios politika žydu atžvilgiu.“ In Lietuvos žydai. Istorine studija. Eds. Vladas Sirutavičius, Darius Staliūnas, Jurgita Šiaučiūnaitè-Verbickienè. Vilnius, 2012.

Trečiojo Seimo stenogramos 1926-1927. Kaunas, 1927.

Truska, Liudas, Lietuviai ir žydai nuo XIX a. pabaigos iki $1941 \mathrm{~m}$. Birželio. Vilnius, 2005.

Truska, Liudas, Vygantas Vareikis. Holokausto prielaidos. Antisemitizmas Lietuvoje XIX a. antroji puse - 1941 m. Birželis. Vilnius, 2004. 


\title{
TUROPEAN REGIONAL INTEGRATION 4 IN THE DRAFTING OF THE EASTERN PACT IN 1934-1935: INTERESTS OF THE BALTIC ENTENTE AND THE LITTLE ENTENTE
}

\section{Dalia Bukelevičiūtè}

Vilnius University, E-Mail: Dalia.Bukeleviciute@if.vu.lt

\section{Acknowledgments}

This paper has been presented at the Fourth international conference on Baltic and Nordic Studies in Romania Empire-building and Region-building in the Baltic, North and Black sea areas hosted by the Romanian Association for Baltic and Nordic Studies and Ovidius University of Constanta, May 24-26, 2013.

\begin{abstract}
:
This article follows the interests and actions of the countries of Baltic and Little ententes with regard to the projected Eastern Pact, which raised marked interest in East-Central Europe in 1934-1935. It seeks to give an answer to the question whether the negotiations over the Eastern Pact brought the interests of the Baltic states closer to those of the Little Entente. It highlights that the progress of negotiations made it clear that each country was more concerned with its security than the common security of the entire bloc, even though both the Little Entente and the Baltic Entente were established for the sake of safeguarding security of their member states and harmonising their foreign policy in this respect. Both regional security bodies declared their agreement to the Eastern Pact but the key difference was that the Baltic Entente was expected to participate in the Eastern Pact directly, whereas only Czechoslovakia was singled out from among the members of the Little Entente. The analysis concludes that Lithuania and Czechoslovakia were the two countries which were most actively concerned with the conclusion of the Eastern Pact.
\end{abstract}

\section{Rezumat:}

Articolul urmărește interesele și acțiunile țărilor membre ale Antantei Baltice și ale Micii Antante cu privire la proiectul Pactului Oriental, proiect care s-a bucurat de un mare interes în Europa Central-Răsăriteană în anii 1934-1935. Acesta caută să dea răspuns întrebării dacă negocierile cu privire la Pactul Oriental au apropiat interesele statelor baltice de cele ale statelor Micii Antante. Este subliniat faptul că 
desfăşurarea negocierilor a vădit faptul că fiecare dintre țări era mai interesată de securitatea sa decât de aceea comună a întregului bloc, deși atât Mica Antantă cât și Antanta Baltică fuseseră concepute pentru salfgardarea securității statelor membre și armonizarea politicii lor externe în acest scop. Ambele structuri de securitate regională și-au declarat acordul față de Pactul Oriental, cu diferența fundamentală că Antanta Baltică era de așteptat să participe direct la Pactul Oriental, în vreme ce dintre membrii Micii Înțelegeri doar Cehoslovacia urma să facă acest lucru. Analiza de față conchide că Lituania și Cehoslovacia au fost cele două state cele mai interesate de finalizarea cu succes a negocierilor pentru semnarea Pactului Oriental.

Keywords: Oriental Pact; Little Entente; Baltic Entente; Czechoslovakia; Lithuania; regional security; collective security

In 1934-1935, the idea of the Eastern Pact forced European states to revise and re-evaluate the possibilities for regional cooperation. In fact, the main idea behind regional cooperation was to safeguard the security of individual states and the security of Europe or, in other words, to maintain peace in Europe. The issues of peace in Europe and security of European states were prompted by the arising tensions in countries' bilateral relations, the division of countries into revisionists and anti-revisionists, the changing balance of powers, i.e. the growing German role and the declining French influence. From 1933 (especially after the withdrawal of Germany) the power of the League of Nations, which was initially founded as a guarantor of peace and stability in Europe, began to decline. Trying not to lose its influence and balancing in the international policy, France started seeking closer relations with the USSR, which was also striving to strengthen its positions. The great powers decided to admit the Soviet Union to the League of Nations as a fullfledged member. Therefore, the mutual relations between France and the USSR, the balancing of Great Britain and an open German and Polish opposition determined the evolution of international relations in 1934-1935.

The circumstances of negotiations over the conclusion of the Eastern Pact have received extensive coverage in historiography. Historians from various countries focus on revealing the interests of individual countries and personalities under these circumstances. In the attempt to reveal the interests of the Little Entente and the Baltic Entente in pursuance of regional cooperation in Europe, the article mostly relies on Lithuanian and Czech archival material; the pro-memorias and diplomatic correspondence of the Lithuanian foreign minister Stasys Lozoraitis are an especially valuable source of important information. Lithuanian historians Z. Butkus and V. 
Žalys, Estonian historian Magnus Ilmjärv, Czech historian Zdeněk Sladek devoted considerable attention to these problems in their works. The tendencies of regional cooperation have been thoroughly addressed by Slovak historian Valerián Bystricky.

The first more serious contacts between France and the USSR were established at the end of 1933 and intensified especially from February 1934, when J.L. Barthou became the French foreign minister. From April the diplomatic discussion launched by the French Foreign Ministry began, which had to lay foundations to "a rather complicated project entitled the Eastern Pact". ${ }^{1}$ By its initial versions, the Eastern Pact had to be concluded on the basis of a regional pact of mutual assistance, a French-Soviet guarantee pact and a general pact of all the signatories. ${ }^{2}$ Though the system established for safeguarding security may seem rather cumbersome and hardly enforceable, V. Bystricky, one of the most prominent researchers in this field, highlighted that with the system of collective security, the international relations were supplemented with an absolutely new form of security organization based on regional pacts among the great powers and the small powers. ${ }^{3}$ Hence, Europe got involved in long-lasting discussions over the safeguarding of security in an absolutely new form, which had not yet been tested and checked in international relations.

According to the initial idea of the Eastern Pact, France, the USSR, Czechoslovakia, Poland, Germany, Lithuania, Latvia, Estonia and Finland were projected as parties to the pact. Most importantly, the parties to the pact did not only have to agree among themselves but also to agree on the general idea of maintenance of security. To bring regional integration to life, bilateral and multilateral relations among the states intertwined among themselves. The greatest concern was Germany's revisionist tendencies and its attempts to revise the Versailles system. Tensions were also fuelled by the PolishGerman non-aggression treaty signed in 1934 and the changes in the Polish foreign policy. On the other hand, not all countries had crystallised their relations in respect of the USSR until that time. The strengthening role of the USSR as one of the initiators was not only an unpopular but also alarming sign among some countries; yet some countries cardinally changed their positions expressed in 1934 in favour of the USSR.

According to historian Bystricky, collective security emerged and developed as a reaction to all the negative events in the international

\footnotetext{
1 Stanisław Żerko, Niemiecka polityka zagraniczna 1933-1939 (Poznań, 2005), 125.

2 Zdeněk Sládek, Malá dohoda 1919-1938 (Praha, 2000), 126

3 Valerián Bystrický, Kolektívna bezpečnost́ anebo neutralita: balkánske štáty a vytváranie záruk bezpečnosti v 30. rokoch (Bratislava, 1981), 139.
} 
situation. ${ }^{4}$ In the Soviet understanding, the Eastern Pact had to bring together all the countries threatened by the German expansion. Hence, Germany was destined to become the central figure in the negotiations. Germany's position was quite the opposite to what the initiators of the Eastern Pact could expect; its diplomacy tried to pave the way for aggression, to seek for allies, to destroy the collective security system, the French security system, to conceal its aggressive plans, etc. ${ }^{5}$ According to the initial idea of the Eastern Pact, it should involve Germany's neighbours. The USSR and France brought their proposals for the participation of individual countries in the Eastern Pact in June 1934. It fuelled an intense discussion on the safeguarding of security, regional integration, and mutual interests.

Germany and Poland were least concerned with concealing their hesitation, doubts or even critical disposition. Finland was the first to refuse participation in the pact. The Finnish foreign minister Antti Hackzell informed Neurath on his visit in Berlin on 9 June that his government would not contribute to the pact. Finland was afraid that the USSR was merely looking for an excuse to deploy its military troops in Finland. ${ }^{6}$ In the meantime, Lithuania and Czechoslovakia, fearing for their potential political isolation and military threats from Germany, were most in favour of the proposal. Czechoslovakia was the first to express its agreement to participate in the Eastern Pact on 2 July, abstaining from any specific reservations. The USSR and France were prone to single out Czechoslovakia from among the members of the Little Entente. The other two member states - Romania and Yugoslavia - were not invited to contribute to the collective security system. Romania demonstrated a certain interest in regional integration. However, according to historian Bystricky, the USSR was rather reserved regarding the Romanian interests to adhere to the Eastern Pact as it was prone to believe that only the countries of the region should accede to the pact. 7 The Soviets were convinced that the Romanian accession could be rather troublesome. It was Józef Beck who spoke for the inclusion of Romania in the Eastern Pact in the beginning of June by simultaneously speaking for the exclusion of Lithuania and Czechoslovakia. ${ }^{8}$ Such Polish interests were sceptically evaluated by Czechoslovakian diplomats fearing that closer relations between Poland and Romania could be a threat to the entire Little Entente. Prague received a message from Warsaw: "It is obvious that ever since the

\footnotetext{
4 Ibid., 139

${ }^{5}$ Ibid., 120

6 Żerko, 127.

7 Bystrický, 145

8 Piotr Wandycz, The twilight of France Eastern Alliances 1926-1936 (Princeton, New Jersey, 1988), 363

42
} 
Polish Foreign Ministry got involved in the conflict with us, it has conspicuously and in every step demonstrated its alliance with Romania and amicable relations with Yugoslavia. It aims to weaken the Little Entente as a unit and to isolate Czechoslovakia". ${ }^{9}$

Even before active negotiations over the Eastern Pact began, the member states of the Little Entente essentially changed their policy in respect of the USSR. The meeting of the Permanent Council of the Little Entente held on 22 January 1934 in Belgrade agreed that it was a favourable moment for normalising the relations with the Soviets. ${ }^{10}$ The Czechoslovakian foreign minister Edvard Beneš saw the alliance with the USSR in the framework of the Eastern Pact as one of the key objectives in the existing situation. ${ }^{11}$ The most strenuous negotiations were expected to take place between the USSR and Romania regarding the controversy over Bessarabia but the countries succeeded in reaching an agreement and Czechoslovakia and Romania established diplomatic relations with the USSR on 9 June 1934.

Yugoslavia did not only refuse to establish relations with the USSR but pursued closer relations with Nazi Germany. Pressed by the international situation and the great powers, Yugoslavia expressed its formal agreement. It did not itself consider any possibilities of joining the Eastern Pact as it was not willing to participate in the regional pact, with the USSR taking part in its drafting. ${ }^{12}$ Thus, according to historian Sladek, "the unity of the Little Entente was in the midst of its first open political crisis manifesting itself by the diverging positions in respect of the Eastern Pact, in particular as regards the normalization of relations with the USSR" ${ }^{13}$ In fact, the conference of the Permanent Council of the Little Entente held on 18-20 June 1934 in Bucharest approved the idea of the Eastern Pact as the pact aiming at the safeguarding of security in Eastern Europe.

On 14 June the USSR made a proposal to the Baltic states, when the three countries were already in the midst of intensive coordination of their actions regarding the establishment of the Baltic Entente. The establishment of the Baltic Entente was often compared to the Little Entente. Czechoslovakian diplomats in Kaunas were exceptionally active and followed both the establishment of the Baltic Entente and the possibilities of countries' participation in the Eastern Pact. Before the first meeting of the

\footnotetext{
${ }_{9}$ Czechoslovakia envoy extraordinary and minister plenipotentiary in Warsaw report of 10.05.1934 from Warsaw to the Ministry of Foreign Affaires of Czechoslovakia, Archive of Ministry of Foreign Affaires of Czech Republic (hereafter, AMZV).Pz-Varšava. 1934. č.j.5017. 10 Sládek, 126

11 Ibid.

12 Bystrický, 149

13 Sládek, 127
} 
representatives of the Baltic states on 7 July in Kaunas, the Czechoslovakian chargé d'affaires Jan Skalicky noted that the Baltic states would consider the principles of their cooperation with regard to the proposal to join the Eastern Pact as well. When evaluating international circumstances, he noted that "Russia supports the alliance of the Baltic states because it sees it beneficial to itself. Poland works against it, while Germany will never agree to any cooperation among the Baltic states which it perceives as a move against it and the expansion of its interests to the East". ${ }^{14}$ France did not oppose to the formation of the Baltic Entente as well. As noted by M. Ilmjärv, "in the spring and summer of 1934 Paris viewed the Baltic League as a part of the Eastern Pact. On June 14, on the request of his government, the French envoy in Riga told Munters that France welcomed the conclusion of the regional agreements in Eastern Europe in the framework of the League of Nations statutes, which later would develop into a wider regional pact. This meant that the Baltic states should not join the Eastern Pact singly, but as a Baltic bloc". 15

Lithuania supported its adherence to the Eastern Pact directly and expressed such a position to the Soviets even before the official proposal. The Lithuanian foreign minister stressed to the USSR envoy Karski that "we support any Russian initiative in this direction"; however, Lithuania brought forward specific requirements as well: "we are concerned that no act is projected, which could prejudice our specific problem, i.e. the Vilnius case, and could make an impression that we are changing our position in respect of the Vilnius issue". ${ }^{16}$ Lithuania had a firm position regarding the Vilnius issue and according to the Lithuanian foreign minister Stasys Lozoraitis, "we cannot enter into any treaties establishing territorial status quo". ${ }^{17}$ In the meantime, Latvia and Estonia approached the situation from their position. On July 3, the Estonian foreign minister Seljamaa revealed the position of the Estonian Government regarding the Eastern Pact to Soviet diplomats: if Germany and Poland decline taking part in the pact, Estonia is not interested in it either, and anyway Estonia in its calculations intends to take also the views of Great Britain into consideration. ${ }^{18}$ Two days later Vilhelms Munters,

\footnotetext{
14 Czechoslovakia Charge d'Affaires in Kaunas Jan Skalický report of 10.07.1934 from Kaunas to the Ministry of Foreign Affaires of Czechoslovakia, AMZV.Pz-Kaunas. 1934. č.j.200-duv.

15 Magnus Ilmjärv, „Estonia, Latvia, Lithuania and the Eastern pact project,“ Acta Historica Tallinnensia 10 (2006): 76

16 A Pro memoria from S.Lozoraitis Lithuanian Minister of Foreign Affairs 30.06.1934, Lithuanian Central State Archive (hereafter LCVA). F.383.Ap.7.B.1557. L.486-487

17 A secret Pro memoria from Stasys Lozoraitis Lithuanian Minister of Foreign Affairs 14.07.1934, LCVA. F.383.Ap.7.B. 1587. L. 145

18 Ilmjärv, 75

44
} 
Secretary-General of the Latvian Foreign Ministry, informed Stefan Brodovski, the Soviet envoy in Riga, that the Eastern Pact without Germany's participation would constitute an anti-German league and therefore would be unacceptable to Latvia. ${ }^{19}$ Lithuania had to accept the position of Latvia and Estonia, which did not change over time.

The Baltic states expressed their agreement to the Eastern Pact Latvia and Estonia on 29 July, Lithuania on 3 August; the same was repeated by Estonian and Lithuanian foreign ministers Seljamaa and Lozoraitis on their visit to Moscow. It was stated in the meeting between Lozoraitis and Litvinov that "the pause is due to the failure of Poland and Germany to pronounce their opinion on this matter", even though it could be sensed that the position of the two countries "is virtually negative but they keep procrastinating the final answer". ${ }^{20}$ When Lozoraitis declared that "we will not participate in any case regarding the Vilnius issue", Litvinov's reaction was as follows: "the conclusion of the pact is impossible without Lithuania. Even as regards the Lithuanian-Polish dispute". ${ }^{21}$

With negotiations over the Eastern Pact in progress, the stand that Lithuania and Czechoslovakia took in their foreign policy, in respect of Poland and Germany in particular, became increasingly closer. The diplomats and foreign ministers of the two countries involved in more active cooperation. Lozoraitis was showing an active interest in the position of Prague in respect of the Eastern Pact. After hearing the favourable opinion of the Czechoslovakian envoy in respect of the Eastern Pact in June, Lozoraitis highlighted that "in respect of the Eastern Pact, Lithuania took up the position identical to that of Czechoslovakia, i.e. it is willing to support every action strengthening the idea of peace".22 Even though the positions in respect of the Eastern Pact coincided, the relations with Poland and Germany got complicated. In 1934 Poland was increasingly more active in bringing forward the issue of national minorities in Czechoslovakia; the LithuanianPolish dispute over Vilnius persisted. German nazi moods got more active in Lithuania and Czechoslovakia; Germany brought claims to both countries over the protection of rights of national minorities. Czechoslovakian diplomats did not conceal the noticeable tactical similarity: "today Poland has not still crystallised its relations with Czechoslovakia and Lithuania, and

\footnotetext{
19 Ibid.

20 A absolutely secret Pro memoria from S.Lozoraitis Lithuanian Minister of Foreign Affairs 22.08.1934, LCVA. F.383.Ap.7.B.1566.L.5

21 Ibid., L.6

${ }^{22}$ Czechoslovakia Charge d'Affaires in Kaunas Jan Skalický report of 27.06.1934 from Kaunas to the Ministry of Foreign Affaires of Czechoslovakia, AMZV.Pz-Kaunas. 1934. č.j. 189-duv.
} 
if we took a closer look at the tactics chosen by the Polish Foreign Ministry to solve the two issues, we would find a lot of analogies". ${ }^{23}$

In August the Czechoslovakian envoy informed from Warsaw that Poland considered Lithuania a huge obstacle in the way of the Eastern Pact: "Poland follows an opinion that it cannot sign a guarantee treaty with a state which does not have diplomatic relations with Poland and which is still living with hopes to retrieve a part of the Polish territory". ${ }^{24}$ To the best of his knowledge, Poland was even taking various measures in respect of this issue: "the Soviet legation witnesses Polish protests against Lithuania by referring to the fact that the Soviets are in no hurry to sign non-aggression treaties with the countries which have not entered into diplomatic relations with it and, finally, which have unresolved territorial issues with it, e.g. Romania".25 Czechoslovakian diplomats were unsettled by a slightly different position followed by Poland in respect of regional cooperation, e.g. it frequently did not consider the Little Entente a single bloc; it expressed a desire for Hungary and Bulgaria to adhere to the pact.

As soon as Poland and Germany expressed their position, a breakthrough in the negotiations began. On 7 July the German foreign minister Neurath declared that Germany would not join the pact. He pointed the fear of the imminent French-Soviet domination in Europe as the main reason. ${ }^{26}$ Poland did not openly criticise the pact but it was nevertheless disturbed by a possibility that it might be required to let the Red Army move across its territory and by the ongoing dispute with Lithuania and Czechoslovakia. ${ }^{27}$ Germany and Poland gave their negative answer to the participation in the Eastern Pact - the former on 11 September, the latter on 27 September. It destabilised the situation and undermined the plans of regional cooperation. There was more uncertainty and various speculations than common agreement and clarity of the situation.

After Poland and Germany expressed their position, Lithuania, as well as Czechoslovakia, continued to hold on to their opinion supporting the conclusion of the Eastern Pact; they supported the calls coming from Moscow diplomats to continue the negotiations over the Eastern Pact. Beneš tried to convince the Lithuanian envoy Turauskas that if Poland contributed to the Eastern Pact, the reservation clause in respect of Lithuania and

\footnotetext{
${ }^{23}$ Czechoslovakia envoy extraordinary and minister plenipotentiary in Warsaw report of 08.05.1934 from Warsaw to the Ministry of Foreign Affaires of Czechoslovakia, AMZV.PzVaršava. 1934. č.j. 4826

24 Ibid., 25.08.1934, Pz-Varšava. č.j.8415

25 Ibid., 25.08.1934, Pz-Varšava. č.j. 8415

26 Żerko, 127.

27 Ibid., 126.

46
} 
Czechoslovakia had to be anticipated: "practically speaking, it would mean that in the event of an attack, Czechoslovakia and Lithuania could not expect help from Poland and vice versa - in the event of an attack, Poland could not expect assistance from Lithuania and Czechoslovakia. ${ }^{28}$ Not only the minister Lozoraitis but also the Lithuanian Government supported this position. Smiling, Lozoraitis then told the Czechoslovakian envoy: "it does not mean that Poland may have free hands". ${ }^{29}$

German and Polish intrigues in respect of the Little Entente did not remain unnoticed in Lithuania. The minister Stasys Lozoraitis and Juozas Urbšys inquired of the Czechoslovakian chargé d'affaires Skalicky what position Czechs followed in respect of the German attempts to attract Yugoslavia to their side. Skalicky replied that "Germany will now seek a shake-up aggravating the Central European consolidation and will be scheming wherever it finds a favourable field for that". ${ }^{30}$ Whereas Lithuanian politicians remained the passive observers of the processes evolving in the Little Entente, Czechoslovakian diplomats were very active in expressing their reaction towards the changing balance of powers: "The Polish actions in Yugoslavia, likewise equivalent actions in Romania, cannot be seen as anything else but a desire to weaken the internal reciprocal relations within the Little Entente and to undermine the mutual relations among the member countries. ${ }^{31}$ The Czechoslovakian envoy in Warsaw warned that the aim behind such actions was to draw Yugoslavia and Romania away from France" and it was even "suspected that Poland and Germany shared the roles for pursuing similar actions in Yugoslavia and Romania in the fulfilment of this aim". 32

At the end of November the minister Beneš expressed his doubts in the policy pursued by Poland and believed that Poland would finally refuse to sign the Eastern Pact. He paid attention to the fact that Poland might start bringing its demands for Romania to be included among the signatories of the pact. It was also the time of Romanian negotiations with the Soviets and Beneš believed that Poland had certain calculations: "the Polish proposal for Romania to join the Eastern Pact is calculated in such a way that a reaction is evoked in Russian and Romanian societies and the road for the

\footnotetext{
${ }^{28}$ Czechoslovakia Charge d'Affaires in Kaunas Jan Skalický report of 30.10.1934 from Kaunas to the Ministry of Foreign Affaires of Czechoslovakia, AMZV.Pz-Kaunas. 1934. č.j. 284-duv.

29 Ibid., 29.11.1934, Pz-Kaunas. č.j.307-duv

30 Ibid., 30. 10.1934, Pz-Kaunas. č.j. 284-duv

31 Czechoslovakia envoy extraordinary and minister plenipotentiary in Warsaw report of 31.10.1934 from Warsaw to the Ministry of Foreign Affaires of Czechoslovakia, AMZV.PzVaršava. 1934. č.j. 10551

32 Ibid., 31.10.1934, Pz-Varšava. č.j. 10551
} 
governments is encumbered". ${ }^{33}$ The Lithuanian diplomacy did not receive information from Belgrade or Bucharest directly as it did not have its diplomats in these countries. It failed to express its position regarding the relations within the Little Entente but continued to consider the Little Entente an example of safeguarding regional stability.

While Europe was overwhelmed with the discussions on the Polish and German participation in the Eastern Pact in autumn 1934, the Baltic states succeeded in reaching a common agreement and the treaty establishing the Baltic Entente was signed in Geneva on 12 September 1934. The Baltic Entente involved in negotiations over the Eastern Pact as a bloc of countries, whereas the Little Entente was represented by Czechoslovakia alone, showing its exclusive amiability to Lithuania and treating the establishment of the Baltic Entente with favour. The Romanian politicians did not express their direct position regarding the establishment of the Baltic Entente. ${ }^{34}$ According to historian Luboš Švec, "the Baltic states were not the initiators of the negotiations; they were meant to play the role of an object". ${ }^{35}$ Hence, the diplomats of the Baltic states "sought to obtain the maximum possible information about the negotiations, not to lose contacts with the events and to maintain their balance among the great powers". 36

It was in its first conference in Tallinn on 30 November - 3 December 1934 that the Baltic Entente voted for the adherence to the Eastern Pact. The Czechoslovakian chargé d'affaires Skalicky noted that by declaring its allegiance to the League of Nations, the Baltic Entente joined other regional alliances like the Little Entente and the Balkan Pact, whereas a united position in favour of the Eastern Pact might be vital for all Baltic states. ${ }^{37}$ However, in reality, alarming differences emerged among the members of the Baltic Entente while the discussions on the Eastern Pact were still in progress. Munters, Secretary General of the Latvian Foreign Ministry, highlighted the necessity to maintain neutrality, though in principle he was

33 Lithuanian envoy extraordinary and minister plenipotentiary in Prague Edvardas Turauskas report of 29.11.1934 from Prague to the Ministry of Foreign Affaires of Lithuania, LCVA.F.648.Ap.1.B.13.L.46

${ }^{34}$ Nevertheless, in spring, when cooperation possibilities were discussed at the meeting of the diplomatic academy in Paris, the Romanian delegate V. Pella highlighted the necessity of close cooperation in the North by referring to the Little Entente as an example. Czechoslovakia Charge d'Affaires in Kaunas Jan Skalický report of 15. 04.1934 from Kaunas to the Ministry of Foreign Affaires of Czechoslovakia, AMZV.Pz-Kaunas. 1934. č.j. 110-duv

${ }^{35}$ Luboš Švec, Československo a pobaltské státy v letech 1918-1939. Vývoj politických a hospodářských vztahů Československa s Litvou, Lotyšskem a Estonskem v meziválečném období (Praha, 2001), 235 36 Ibid., 235

37 Czechoslovakia Charge d'Affaires in Kaunas Jan Skalický report of 14.12.1934 from Kaunas to the Ministry of Foreign Affaires of Czechoslovakia, AMZV.Pz-Kaunas. 1934. č.j. 330-duv 48 
prone to support the Eastern Pact with Germany and Poland in it. Estonia was even more critical in respect of the possibilities of safeguarding security in Europe with its foreign minister Seljamaa asserting that the three countries must pursue an independent foreign policy. Lozoraitis did not request for Poland's and Germany's adherence to the pact. 38

The initiators of the Eastern Pact were well aware of the diverging orientation of Lithuania, Latvia and Estonia. It was even before the conference in Tallinn that Litvinov expressed his confidence in the establishment of the Baltic Entente to the Lithuanian envoy Petras Klimas but he nevertheless doubted that Lithuania would succeed in neutralising the Latvian and Estonian Polonophilism and Germanophilism. ${ }^{39}$ Beneš, as well, addressed the diverging moods of the Baltic states for a number of times by highlighting that the Baltic states "do not have a single position in respect of the Eastern Pact", Latvia and Estonia had certain doubts as to giving permission to the Russian army to move across their territories, whereas Lithuania did not find it relevant. ${ }^{40}$ Beneš was worried that under such circumstances Poland would attempt to exert its influence on Latvians and Estonians. ${ }^{41}$

The single voice in respect of the Eastern Pact among the members of the Baltic Entente was continuously lacking. On 5 December 1934, the USSR and France signed a protocol on the resumption of negotiations and the commitment not to enter into any treaties which could interfere with concluding the Eastern Pact. Czechoslovakia adhered to the protocol several days later; Lithuanian diplomats encouraged the Lithuanian Government not to procrastinate as well. After receiving information from diplomatic sources that "Beneš is absolutely convinced that Germany and Poland will not adhere to the pact and the pact will not be put to life", the Lithuanian envoy in Paris Petras Klimas encouraged the Lithuanian Government to seek for allies among the members of the Little Entente and the Balkan countries

\footnotetext{
38 Магнус Ильмярв, Безмолвная капитуляция. Внешняя политика Эстонии, Латвии и Литвы между двумя войнами и утрата независимости (с середины 1920-х годов до аннексии $b$ 1940) (Москва , 2012 г.) 155.

39 A Pro memoria from Petras Klimas Lithuanian envoy extraordinary and minister plenipotentiary in Paris (the conversation with Soviet Foreign Minister Maxim Litvinov in Geneva) 21.11.1934, LCVA.F.648.Ap.1.B.26.L.165

40 Lithuanian envoy extraordinary and minister plenipotentiary in Prague Edvardas Turauskas report of 29.11.1934 from Prague to the Ministry of Foreign Affaires of Lithuania, LCVA.F.648.Ap.1.B.13.L.46

${ }^{41}$ Ibid., L.46
} 
but "be cautious with Latvians and Estonians". 42 It was believed that a new regional group of countries was about to emerge: "That formation which through Czechs would be linked with the Little Entente and the Balkans would become a great peace guarantee protecting Europe against any Germany's "friends"". ${ }^{43}$ Lithuania and Latvia agreed to adhere to the protocol, while Estonia refused to do it. ${ }^{44}$ The members of the Baltic Entente did not join the protocol.

In the beginning of 1935 the relations of Lithuania and Czechoslovakia with Poland and Germany did not witness any changes; the position of Poland and Germany in respect of the Eastern Pact did not change as well. In the beginning of February 1935 the USSR envoy in Prague Aleksandrovsky explained to the Lithuanian envoy Turauskas that Poland was expecting to direct the German territorial expansion towards Austria; from there Germans could march to Southern Russia and Bessarabia. According to him, it could explain why the Romanian-Polish alliance was destabilised at that time and why Nicolae Titulescu was so eagerly supporting the Eastern Pact. ${ }^{45}$ Hence, the conduct of Poland and Germany played a role in the further actions of the Baltic Entente and the Little Entente. In evaluating the Lithuanian foreign policy orientation, Skalicky noted: "today Poland is in the best relations with Germany which is at conflict with Lithuania, while Poland is in uncertain relations with Russia whose relations with Lithuania are getting increasingly closer" ${ }^{46}$

In fact, in the beginning of 1935 the international arena was full of various speculations about the expected changes in the primary idea of the Eastern Pact. Lithuania was worried that "the Baltic states could be eliminated from any creative process of the pact altogether" ${ }^{\prime 7}$ The Baltic states were unsettled by the fact that the USSR might start considering other regional combinations with no place for the Baltic states in them. The minister Stasys Lozoraitis also warned the USSR envoy Karski that if the Eastern Pact was doomed to failure and other combinations among the great

\footnotetext{
42 Lithuanian envoy extraordinary and minister plenipotentiary in Paris Petras Klimas report of 12.12.1934 from Paris to the Ministry of Foreign Affaires of Lithuania, LCVA.F. 383.Ap.7.B. 1610.L. 53-54

${ }^{43}$ Ibid., L.52

44 Ильмярв, 156-157.

45 Lithuanian envoy extraordinary and minister plenipotentiary in Prague Edvardas Turauskas report of 08. 02.1935 from Prague to the Ministry of Foreign Affaires of Lithuania, LCVA.F.648.Ap.1.B.14.L. 53

46 Czechoslovakia Charge d'Affaires in Kaunas Jan Skalický report of 15. 01.1935 from Kaunas to the Ministry of Foreign Affaires of Czechoslovakia, AMZV.Pz-Kaunas. 1935. č.j. 21-duv

47 A Pro memoria from Petras Klimas Lithuanian envoy extraordinary and minister plenipotentiary in Paris (from Geneva) 19.01.1935, LCVA.F.648.Ap.1.B.27.L. 32 50
} 
powers were considered, it should not be forgotten that "those combinations would not be complete if the Baltic states were forgotten". ${ }^{48}$ It should be noted that despite having no instructions, Karski reassured that even if the Eastern Pact was doomed to fail, other ways for safeguarding security would be sought, by adding that "Russians and the French should spare no effort in trying to convince Latvians and Estonians." 49

Struck by the growing uneasiness, Lithuanian diplomats shared these moods with Beneš as well. However, he failed to answer whether he preferred the possibility of the pact with Poland and Germany or without them. Beneš believed that Czechoslovakia would contribute to the alliance between the USSR and France if it was concluded and was convinced that the Baltic states would do the same. The situation being rather obscure, the Lithuanian envoy Turauskas proposed closer cooperation between the Little Entente and the Baltic Entente believing that it was "the right moment for establishing a closer contact" (by means of visits, meetings in Geneva). He believed that such cooperation "would help the medium and small countries to show solidarity on important issues". The Czechoslovakian foreign minister avoided a direct answer and explained that the cooperation should not "create an impression that it is targeted against Germany or Poland. What is more, Russians could also suspect that it is targeted against them... Therefore, such cooperation was only possible "en étroite colloboration avec la Russie". ${ }^{50}$ The Lithuanian diplomat agreed to the rather reserved position expressed by Beneš but both politicians were well aware that small and medium-sized states had to establish closer cooperation, in particular with regard to the interests of the great powers.

After the visit of the French foreign minister Laval to London on 1-3 February 1935, the possibility of various regional combinations in the absence of Germany and Poland was openly discussed. The Baltic states found it important to hear about their destiny in such a scheme. ${ }^{51}$ The Lithuanian envoy in Riga got an impression that Munters avoided to give the final answer and started considering whether the Eastern Pact would at

\footnotetext{
48 A Pro memoria from Stasys Lozoraitis Lithuanian Minister of Foreign Affairs 31.01.1935, LCVA. F.383.Ap.7.B.1731. L.200

49 Ibid., L.200

50 Lithuanian envoy extraordinary and minister plenipotentiary in Prague Edvardas Turauskas report of 25.01.1935 from Prague to the Ministry of Foreign Affaires of Lithuania, LCVA.F.648.Ap.1.B.14.L.25-26

51 A secret Pro memoria from Stasys Lozoraitis Lithuanian Minister of Foreign Affairs 19.02.1935, LCVA. F.383.Ap.7.B. 1770. L.23-24
} 
all make any sense without Poland and Germany. ${ }^{52}$ In the meantime, "Estonians consider such issues premature, threatening to their interests and incompatible with their traditional policy". 53 The position of the three members of the Baltic Entente diverged. The Lithuanian minister Lozoraitis was no longer convinced by Skalicky's considerations about how the negotiations would be continued and if the issue of security of Eastern Europe was not solved, it would not be solved in the West or even in the South. ${ }^{5}$ He was also increasingly more sceptical regarding Karski's reassurances that "Russians and the French are firmly determined to bring the action of the Eastern Pact to a successful end". 55

The envoys from the Baltic states delivered démarches in Paris and London - on 9 March in the former and on 13 March in the latter. An interest was expressed to participate in the Eastern Pact and attention was paid to the situation which could evolve if the Baltic states did not participate in the security system. The Latvian envoy was reassured in Paris that "the agreement concluded with Russians in Geneva is strictly followed and in the meantime there can be no question of any modifications whatsoever" ${ }^{\prime 56}$ While in Kaunas, Lozoraitis expressed in plain language when talking to Skalicky how important it was for the Lithuanian Government that Prague was well aware of the situation and that it supported Lithuania on the Eastern Pact. ${ }^{57}$ The Baltic states could sense that the negotiations over the Eastern Pact moved to the capitals of the great powers and they were no longer directly involved in them.

On 6 April the USSR asked the three Baltic states through diplomatic channels whether they would agree to participate in the pact without Poland and Germany participating in it. It was already a proposal of a new regional combination. After discussing the matters with Latvian and Estonian envoys

\footnotetext{
52 Lithuanian envoy extraordinary and minister plenipotentiary in Riga Juozas Urbšys report of 20.02.1935 from Riga to the Ministry of Foreign Affaires of Lithuania, LCVA.F. 383.Ap.7.B. 1494 a. L. 84

53 Lithuanian envoy extraordinary and minister plenipotentiary in Tallinn Bronius Dailidè secret report of 23.02.1935 from Tallinn to the Ministry of Foreign Affaires of Lithuania, LCVA.F.383.Ap.7.B. 1770. L.19

54 Czechoslovakia Charge d'Affaires in Kaunas Jan Skalický report of 14.02.1935 from Kaunas to the Ministry of Foreign Affaires of Czechoslovakia, AMZV.Pz-Kaunas. 1935. č.j. 65-duv

55 A Pro memoria from Stasys Lozoraitis Lithuanian Minister of Foreign Affairs 05.03.1935, LCVA. F.383.Ap.7.B.1731. L. 196

${ }^{56}$ Lithuanian envoy extraordinary and minister plenipotentiary in Paris Petras Klimas report of 09.03.1935 from Paris to the Ministry of Foreign Affaires of Lithuania, LCVA.F. 383.Ap.7.B. 1492 a. L. $41-42$

${ }^{57}$ Czechoslovakia Charge d'Affaires in Kaunas Jan Skalický report of 16. 03.1935 from Kaunas to the Ministry of Foreign Affaires of Czechoslovakia, AMZV.Pz-Kaunas. 1935. č.j. 90-duv 52
} 
in Kaunas, the Lithuanian president and the prime minister, Lozoraitis decided to give the answer after the Stresa Conference. ${ }^{58}$ On 10-11 April, Riga hosted a meeting of Baltic diplomats which considered the interests of all countries and decided to give their final answer after the conference of the Baltic Entente to be held in Kaunas in the beginning of May.59 When talking to Kraski, Lozoraitis noted: "we could not put any more pressure on our Baltic allies and thus postponed the issue by trying to avoid any possible split" ${ }^{60} \mathrm{He}$ once again highlighted that in order to make influence on Tallinn and Riga, Lithuanian steps were not sufficient; Russians and the French had to make them as well. ${ }^{61}$ In the meantime, Beneš, as indicated by subsequent events, accurately identified the USSR goals by warning Lithuanian diplomats that such an inquiry might only be a manoeuvre before the Stresa Conference. ${ }^{62}$ Beneš himself declared to the Lithuanian envoy that he would also support a six-party pact if a different agreement was not possible. ${ }^{63}$

In April the consideration on other possible regional blocs by the members of the Baltic Entente began. Lozoraitis even asked Karski whether such a combination would be possible if Lithuania was the only Baltic state joining it. ${ }^{64}$ A question was even brought up in Riga whether the Baltic states should not offer some new ideas for safeguarding security. Munters was prone to believe that the security of Eastern Europe could best be safeguarded by such a combination which would consist of the USSR, the Baltic states, Poland and Germany, whereas Czechoslovakia would be excluded as it does not share a common border with the USSR. If Czechoslovakia expressed its intention to participate, Hungary and Romania would then have to be included as well. ${ }^{65}$

In the meetings held in Geneva in the middle of May Litvinov was more preoccupied with the matters of the Little Entente and France. Litvinov

\footnotetext{
58 A Pro memoria from Stasys Lozoraitis Lithuanian Minister of Foreign Affairs, LCVA. F.383.Ap.7.B.1731.L.188-189

59 reikalu ministrai: 1918-1940 (Kaunas 1999), 301.

60 A Pro memoria from Stasys Lozoraitis Lithuanian Minister of Foreign Affairs 16.04.1935

(the conversation with Soviet Minister in Kaunas Mihail Karski), LCVA. F.383.Ap.7.B. 1673.L.17

61 Ibid., L.17

62 Lietuvos užsienio..., 302

63 Lithuanian envoy extraordinary and minister plenipotentiary in Prague Edvardas Turauskas report from Prague to the Ministry of Foreign Affaires of Lithuania, LCVA.F.648.Ap.1.B.14.L. 174

64 A Pro memoria from Stasys Lozoraitis Lithuanian Minister of Foreign Affairs 16.04.1935 (the conversation with Soviet Minister in Kaunas Mihail Karski), LCVA. F.383.Ap.7.B. 1673.L.17

65 A Pro memoria from Juozas Urbšys Lithuanian envoy extraordinary and minister plenipotentiary in Riga 15.04.1935, LCVA. F.383.Ap.7.B.1673. L.23-24.
} 
explained to Klimas that the abstention of the members of the Baltic Entente from giving the answer regarding the six-party pact and its forwarding to the conference in Kaunas showed that the Baltic states "were actually indifferent in this respect". The Soviets were not planning to bring up that question again and the Baltic states "chose that isolation by themselves". ${ }^{66}$ This time he said in plain language: "We will not make any more proposals because you are not concerned with your own interests... Finally, the French are not willing to give you any guarantees as well, they do not want to offer assistance and we have no reason to request what you yourself are avoiding...". ${ }^{67}$ When Klimas inquired why Russians cannot enter into such a treaty with the Baltic states which was anticipated to be concluded with Czechs, Litvinov reminded that France was not willing to help the Baltic states, the more so Lithuania. ${ }^{68}$ On his part, E. Beneš was calm and pronounced that "he would sign everything that the French and Russians agree upon" 69 and calmed Lithuanians by saying that if the French were not willing to give Lithuania any guarantees, especially as regards the German aggression, "no pessimistic conclusions should be drawn" from it. ${ }^{70}$ By reassuring that there was no actual threat to Lithuania from the side of Germany, Beneš tried to convince that "the task of peace is a long-lasting task and it will never end", whereas the unrealised Eastern Pact could be replaced with some other project. ${ }^{71}$

There, the French made it clear that, should Germany reject the Eastern pact, they intended to negotiate 'some agreement' with Soviet Russia.72 The resolution in the negotiations over the Eastern Pact became the signing of mutual assistance treaties between the USSR and France on 2 May 1935 and between the USSR and Czechoslovakia on 16 May 1935. Thus, Czechoslovakia, as a member of the Little Entente, achieved, at least for the time being, certain security commitments in its respect, whereas the members of the Baltic Entente were left behind. In fact, in the conference of the Baltic Entente held in Kaunas on 6-8 May the Little Entente was referred to as seeking to safeguard security in Europe, whereas the members of the

\footnotetext{
${ }^{66}$ Lithuanian envoy extraordinary and minister plenipotentiary in Paris Petras Klimas report of 15-19.04.1935 from Geneva to the Ministry of Foreign Affaires of Lithuania, LCVA.F. 648.Ap.1.B.27.L. 258

67 Ibid., L. 258

68 Ibid., L. 259

69 Ibid., L.265

70 Ibid., L.265

71 Ibid., L.265-266

72 Keith Neilson, Britain, Soviet Russia and the Collapse of the Versailles Order, 1919-1939 (New York 2006), 133.

54
} 
Baltic Entente undertook in the resolution of the conference to put every possible effort for safeguarding security and that the efforts made in the drafting of the Eastern Pact would be fruitful. ${ }^{73}$ Skalicky was prone to doubt whether the great powers were willing to strengthen the security of the Baltic Entente; they were most likely more willing to enhance their expansion in the region. ${ }^{74}$

The negotiations over the Eastern Pact brought the interests of the Baltic states closer to those of the Little Entente as all countries were concerned with safeguarding security. Poland and Germany were the key factor of insecurity. However, the progress of negotiations made it clear that each country was more concerned with its security than the common security of the entire bloc, even though both the Little Entente and the Baltic Entente were established for the sake of safeguarding security of their member states and harmonising their foreign policy in this respect. Both the Little Entente and the Baltic Entente declared their agreement to the Eastern Pact but the key difference was that the Baltic Entente was expected to participate in the Eastern Pact directly, whereas only Czechoslovakia was singled out from among the members of the Little Entente. Lithuania and Czechoslovakia were the two countries which were most actively concerned with the conclusion of the Eastern Pact and most eagerly supported the idea of regional integration. Romania supported the idea of the Eastern Pact; however, the process of negotiations did not bring it closer to the Baltic states; Lithuanian diplomats did not have any direct contacts with Romanians as well; they did not pay close attention to Romanian interests. Latvia was the only country which had a chance to hear out the Romanian position through its representation in Warsaw. In 1935 other possible ideas of regional integration involving the members of the Baltic Entente and the Little Entente were already discussed but an extensive range of interests prevented them from achieving broad regional integration in Europe.

\section{References:}

\section{A. Archives:}

Archive of Ministry of Foreign Affaires of Czech Republic (AMZV):

\footnotetext{
73 The resolution of the Second Baltic Entente Conference 08.05.1935 Kaunas. In: Zenonas Butkus, Česlovas Laurinavičius, eds. Baltijos valstybiu vienybès ideja ir praktika 1918-1940 metais (Vilnius, 2008), 557.

${ }^{74}$ Czechoslovakia Charge d'Affaires in Kaunas Jan Skalický report of 10.05.1935 from Kaunas to the Ministry of Foreign Affaires of Czechoslovakia, AMZV.Pz-Kaunas. 1935. č.j.158-duv
} 
- Pz-Kaunas. 1934. č.j. 110-duv, 189-duv, č.j.200-duv., č.j. 284-duv, č.j.307-duv, č.j. 330-duv

- Pz-Kaunas. 1935. č.j. 21-duv, č.j. 65-duv, č.j. 90-duv, 158-duv

- Pz-Varšava. 1934. č.j. 4826, Pz-Varšava. č.j.8415, č.j. 10551

Lithuanian Central State Archive (LCVA):

- F.383.Ap.7, B. 1492, B. 1494, B.1557, B.1566, B. 1587, B. 1610, B. 1673, B.1731, B. 1770

- F.648. Ap.1. B.13, B.14, B.26, B.27

B. Books and articles:

Butkus, Zenonas, Česlovas Laurinavičius, eds. Baltijos valstybiu vienybejs ideja ir praktika 1918-1940 metais. Vilnius, 2008.

Bystrický Valerián. Kolektíona bezpečnost' anebo neutralita: balkánske štáty a vytváranie záruk bezpečnosti v 30. rokoch. Bratislava, 1981.

Ilmjärv, Magnus. "Estonia, Latvia, Lithuania and the Eastern pact project." Acta Historica Tallinnensia 10 (2006).

Ильмярв, Магнус [Ilmjärv, Magnus]. Безмолвная капитуляциия. Внешняя политика Эстонии, Латвии и Литвы между двумя войнами и утрата независимости (с середины 1920-х годов до аннексии в 1940) [Silent submission: formation of foreign policy of Estonia, Latvia and Lithuania (period from mid-1920s to annexation in 1940)]. Москва , 2012.

Lietuvos užsienio reikalu ministrai: 1918-1940. Kaunas 1999.

Neilson, Keith. Britain, Soviet Russia and the Collapse of the Versailles Order, 1919-1939. New York 2006.

Sládek, Zdeněk. Malá dohoda 1919-1938. Praha, 2000.

Švec Luboš. Československo a pobaltské státy v letech 1918-1939. Vývoj politických a hospodářských vztahů Československa s Litvou, Lotyšskem a Estonskem v meziválečném období. Praha, 2001.

Wandycz Piotr. The twilight of France Eastern Alliances 1926-1936. Princeton, New Jersey, 1988.

Żerko, Stanisław. Niemiecka polityka zagraniczna 1933-1939. Poznań, 2005. 


\title{
FINLAND'S RAPPROCHEMENT TO NATIONAL-SOCIALIST GERMANY AS REACTION AGAINST WINTER WAR
}

\section{Kalervo Hovi}

University of Turku, E-Mail: kalervo.hovi@gmail.com

\section{Acknowledgments}

This paper has been presented at the Fourth international conference on Baltic and Nordic Studies in Romania Empire-building and Region-building in the Baltic, North and Black sea areas hosted by the Romanian Association for Baltic and Nordic Studies and Ovidius University of Constanta, May 24-26, 2013.

\begin{abstract}
:
The aim of this article is to analyse the reasons behind the Finnish co-belligerency with Germany in the Operation Barbarossa. The investigation reveals the main reasons and key moments which contributed to Finnish rapprochement with Nazi Germany following the Winter War when their relations reached the nadir. Therefore, the article looks at the attitude of Finnish, German and Soviet decisionmakers following the Winter War and sets the Finnish decision within the frame of Finnish national interest as defined by its elites and not in an ideological choice of Totalitarian doctrine of National-Socialism. Ironically, after cooperating in the war against Soviet Union, Finland and Germany became open enemies after the Finnish armistice with Soviet Union was concluded.
\end{abstract}

\section{Rezumat:}

Scopul acestui articol este acela de a analiza rațiunile care explică cobeligeranța Finlandei cu Germania în cadrul Operațiunii Barbarossa. Investigația relevă principalele rațiuni și momentele cheie care au contribuit la apropierea Finlandei de Germania Nazistă după ce în timpul Războiului de Iarnă relațiile dintre cele două state ajunseseră la nadir. Prin urmare, articolul dezvăluie atitudinea factorilor de decizie finlandezi, germani și sovietici după încheierea Războiului Rece și plasează decizia finlandeză în cadrul interesului național finlandez așa cum a fost acesta definit de elitele finlandeze și nu ca pe o alegere ideologică în favoarea doctrinei totalitare a național-socialismului. Este paradoxal faptul că după ce au colaborat în războiul împotriva Uniunii Sovietice, Finlanda și Germania au devenit state inamice în urma semnării armistițiului dintre Helsinki și Moscova. 
Keywords: Finland; Germany; Soviet Union; Winter War; Continuation War; Operation Barbarossa

7 he relations between Germany and Finland have been fairly good for centuries. Trade connections have been lively and highly profitable for Finns. Since the 15th century the universities of Northern Germany provided the highest education available. The reformation spread from Germany, and the Finnish reformer Mikael Agricola was Melanchton's student in Wittenberg. The Reichsregierung supported the Finnish independence with advice and armed support in 1917-1918. So Germany, be it Imperial Germany, the Republic of Weimar or National-Socialist Germany, was Germany, above all, for most Finns.

The political pressure of the dictatorial powers against small states began to be felt as soon as 1937, but the Hitler-Stalin-Pact of August 1939 constituted a real shock. One had thought that the Nazi-Soviet antagonism is an axiom, and the Finns felt it particularly important that Germany could remain as a counterweight against the Soviet Union. The nations of the area could not expect anything good from the pact, but the division of the spheres of interest was fatal. The results were soon to be seen. Poland was attacked and divided by Germany and the Soviet Union. At the same time, the Soviet Government started to demand cessions of territory and military bases from her Western neighbours.

The Soviets demanded frontier rectifications from Finland, too. Above all, the Finnish frontier on the Karelian Isthmus ought to be drawn some $70 \mathrm{~km}$ westwards. Furthermore, the Russians required a naval base on the Western Coast of Finland and a pact of mutual assistance. The Baltic States had consented to similar demands. Marshal Mannerheim and the former Ministerpresident and future President of the Republic J.K. Paasikivi, who knew Russia well, recommended concessions, but the Finnish Government did not want to give in straight away. The pact of mutual assistance and the military base were out of the question, and on the Karelian Isthmus they did not want to yield much of the ancient Finnish soil. The Finnish delegation, led by Paasikivi travelled three times to Moscow in order to negotiate. The gap between the latest Russian demands and Finnish concession was only $20 \mathrm{~km}$ of land, but the demands for a naval base in the West and above all the pact of mutual assistance were seen as incompatible with the Finnish independence. At this phase, the Russian Government 
broke off the negotiations, denounced the treaty of non-aggression and started a war against Finland on November 30th, $1939 .{ }^{1}$

So Russia, whose Government until this day claims that they have never started a war, nevertheless attacked. The first attack was a political one. A puppet government was established under Finnish exile in Moscow, communist O.V. Kuusinen. He accepted all Russian demands. The endeavour was masked on the 1st of December as a Finnish people's government, pretending to assemble at the Karelian Parish Terijoki. On that day, Terijoki was still in the hands of Finnish covering forces. ${ }^{2}$

After the outbreak of the war, Germany practised a strict but proSoviet neutrality. Hitler is said to have published in the Völkischer Beobachter on the 8th of December an article where he denied all German responsibility for events in the North and blamed the Finns of harbouring a hostile attitude towards the Germans. That was a turn that was horrid, and the Finns employed considerable effort to improve relations with Germany. There were only private expressions of sympathy, official Germany remained chilly. Later on Hitler tried to show regret, and in June 1942 he came to Finland to congratulate Mannerheim on his 75th birthday. ${ }^{3}$ Only Reichsmarschall Göring let some light show through the clouds. He wrote to Marshal Mannerheim at the beginning of November: "Please concede in the discussions with Russia. Germany cannot help at the moment, but afterwards we shall compensate everything."4

The Finnish Government did not trust those vague promises, but decided to defend herself. She was supported by the sympathy wave of the world's public opinion. Furthermore, many states helped Finland with armament and volunteers, above all Sweden and Italy. Even Göring had let "by mistake" some armament come through. When the Russians rigorously watched the behaviour of the Germans, it was agreed that Sweden would supply the Finns with armament from her depots and these would then be

\footnotetext{
1 Jukka Tarkka, Neither Stalin nor Hitler. Finland during the Second World War, transl. by David Mitchel (Helsinki, 1991), 9-12.

2 See Osmo Jussila, Terijoen hallitus 1939-1940 [The Terijoki Gióvernment, 1939-1940] (Helsinki, 1985).

${ }^{3}$ Gerd R. Ueberschär, Hitler und Finnland 1939-1941. Die deutsch-finnischen Beziehungen während des Hitler-Stalin-Paktes (Wiesbaden: Frankfurter Historische Abhandlungen 16, 1978), 111-117. See also Jukka Parrtanen, Manerheim ja Hitler [Mannerhein and Hitler] (Helsinki, 2012).

4 Risto O. Peltovuori, Saksa ja Suomen talvisota [Germany and the Finnish Winter War] (Helsinki 1985), 51-52.
} 
compensated by Germany. ${ }^{5}$ So even the German sins were not as blood-red as they looked.

The Russians first thought that they can cope with Finland with the strengthened forces of the military district of Leningrad, as such more populated than the whole of Finland. This did not succeed. The Finns managed to keep the main defence line in the Karelian Isthmus for over two months, and the attacks in the wide areas in the North were repelled by a moving warfare. Then the Soviet Union took recourse to her whole Great Power army, and at the end of February 1940 the Russians attained a limited breakthrough. ${ }^{6}$

The Finnish Government had to consider the possibilities of peace. Great Britain and France had promised an active support, and this was an alternative. 7 Still new emissaries were sent to Berlin, too, and at the end of February they were suddenly received at the highest level. Göring stressed again that Finland should make peace as soon as possible. It was most important that Finland could remain independent. The war between Germany and the Soviet Union would break out in the nearest future, and the temporary losses could be compensated later on. ${ }^{8}$

The Finnish Government decided to make peace at the end of February. Decisive reasons were that the strength of the Finnish armed forces began to be exhausted. The effective help of the Western Powers was at the end not believed in, but the possibility of Western intervention was probably responsible for the fact that Stalin was ready to let Kuusinen's government fall and make peace with the legal government of Finland. The words of Prime Minister Ryti might have been decisive, too: "We have to make peace with no delay, in order to keep the army capable to fight so that Finland under better conditions will be strong enough. It is better to start the recapture of Karelia from Vyborg (in Karelia) than from Tornio (at the Swedish border). So the decision was made in great lines according to the

\footnotetext{
5 Ibid., 89-70.

${ }^{6}$ Lasse Laaksonen, "Kannaksen taistelut" [Combats on the Karelian Isthmus], Talvisodan pikkujättiläinen [Concise History of the Winter War], eds. Rari Leslien and Antti Juutilainen. (Helsinki 1999), 435-453.

7 Jukka Nevakivi, Appeal that was never Made, Allies, Scandinavia and the Finnish Winter War 1939-1940 (London, 1976).

${ }^{8}$ Heikki Ylikangas, "Saksa ja Suomi talvisodasta välirauhaan" [Germany and Finland from the Winter war to the Interim peace], in Heikki Ylikangas, Tulkintani talvisodasta [My interpretation of the Winter War] (Helsinki, 2000), 182-184.
} 
recommendation of Göring. The peace was signed in Moscow on March 13th, $1940 .{ }^{9}$

The peace conditions were severe. Finland had to give up the entire Karelian Isthmus with Vyborg. Also parts of parishes Kuusamo and Salla as well as Petchenga on the Eastern border had to be given up. Finns had to rent the Cape of Hanko in Western Finland to the Soviet Union for a naval base but the feared pact of mutual assistance could be avoided. Some 23500 Finnish soldiers had died, and 420000 Karelians were resettled in the rest of Finland. The starting of the war by the Russians and the harsh peace terms were felt deeply unjustified in Finland. This kind of peace could only been seen as a truce, as an interim peace. 10

And the peace did not end the political pressure from the side of the Russians. New demands, provocations and crises caused insecurity in the country. The Finns could also watch from the nearest vicinity how the Russians behaved in the Baltic States. In this tense situation the Finns waited for signs of the altered attitude of Germany. When the Germans again offered weapons and asked for permission to pass German furlough soldiers via Finnish territory to Norway in August 1940, the Finnish government immediately consented. ${ }^{11}$ Then the rapprochement proceeded rapidly. In November, Hitler turned away the demands of Soviet Foreign Minister Molotov. Molotov wanted to have free hands to arrange the Finnish affairs like the Soviets had done in the Baltic States, i.e. to occupy the country. ${ }^{12}$ In this phase Germany has raised her umbrella over Finland.

In December it was already obvious that Germany will attack. Mannerheim had sent his trustee General Paavo Talvela to Germany. When Colonel General Franz Halder, Chief of the German General Staff asked how long the mobilization of the Finnish army to the border would take and which was the bearing capacity on the roads of Northern Lapland, the meaning of the questioning was clear for the Finnish general. Germany prepared to attack very soon, and the Finnish Government decided to go on

\footnotetext{
9 Ibid., 193-202.

${ }^{10}$ Martti Turtola, "Katkera rauha ja Suomen ulkopoliittinen asema" [The Bitter Peace and the position of Finnish foreign policy], in Talvisodan pikkujättiäinen [The Concise History of the Winter War], toim/ eds. Jari Leskinen, Antti Juutilainen (Helsinki, 1999).

11 Mauno Jokipii, Jatkosodan synty. Tutkimuksia Saksan ja Suomen sotilaallisesta yhteistyöstä 194041 [Emergence of the Continuation War. Researches of the German and Finnish Military Cooperation 1940-41] (Helsinki 1987).

12 Ibid., 193-119.
} 
with it, in order to reconquer Karelia. General Erik Heinrichs, Chief of the Finnish General Staff, had permission from the Finnish political leadership to reveal the country's operational preparedness and to outline the grouping of its main troops to the Germans at the end of January 1941. A delegation of officers for final discussion was sent to Germany in May ${ }^{13}$. When the war in summer 1941 broke out, Göring was given a very high Finnish distinction as an expression of gratitude for the advice in February 1940. ${ }^{14}$

So the Finnish decision originated in her own national interest. The Finnish government wanted to have back the territory which unjustified and violently had been taken from her a good year earlier. In the circumstances this was possible only with the help of Germany, the only Great Power willing and capable to help in this endeavour. It was no conscious choice in the global struggle between totalitarism and democracy. Finland herself was a relatively well established democracy and the only aggressor against Finland was the Soviet Union which by no means could be held as a democracy and defender of freedom of the peoples. On the other hand the Finns were not blindly German-oriented. In the fight against the devil they were ready to take help even from Beelzebub.

Finnish historiography has not willingly identified Finland with the other allies of Germany. There have been long discussions if Finland was an ally or a co-warrior. Most practical details of the cooperation on the Northern front were negotiated together, but no political pact was ever made. Finland as a co-warrior had also preserved her full right of decision. Despite continuous German demands Mannerheim refused to attack Leningrad or cut off the main line of the Murmansk railway. As a former Russian general he knew that after such fatal decisions there was no way to a reasonable peace. Mannerheim refused to take the German troops in Finland under his command, too. So he did not need to take orders from the German on command matters. Finland was the only state on the German side which protected her Jewish minority. The Jews as equal Finnish citizen were national servicemen, too. So it happened that the Jewish soldiers in Finland fought together with NS-Germany against the Soviets. ${ }^{15}$ This was totally unique. On the other hand there were peculiarities in the policy of the other

\footnotetext{
13 Tarkka, 36-37,

14 Kalervo Hovi, “Göring ja Talvesõda” [Göring and the Finnish Winter War], Tuna 1 (2006), 79 .

15 See Hannu Rautkallio, Suomen juutalaisten aseveljeys [The Comradeship of arms of the Finnish Jews], (Helsinki, 1989).
} 
German allies, too. It was decisive that Finland could not have waged war without Germany.

On the other hand it is equally clear that there had not been the Continuation War of 1941-1944 without the Russian attack and annexations during the Winter War. Finland was very righteously inclined since the oppressive phase of the Russian dominance in Finland at the turn of the century and this was clearly seen in the Finnish attitude in the Winter War. But when the Finns saw how the Soviet Union and other Great Powers could treat smaller nations, they smoothly began to change. When Germany started her offensive against the Soviet Union in June 1941, the Finns followed after a while. Even if the attack was well prepared beforehand, the Russians lost their nerves and first bombarded Helsinki and other Finnish cities and provided Finland with a legal excuse for the war. When the Finnish attack succeeded well, the attitude of the Finns changed further. Despite some doubts they did not stop at the old border. They continued their advance towards Eastern Karelia, in order to get the line of the great lakes easier to defend. Eastern Karelia, which had never directly belonged to Finland, was important as an ethnically related area and one of the cradles of the Finnish culture, too. For example, the Finnish national epic was found in Eastern Karelia. When the German offensives proceeded well, there arose hopes of getting even Eastern Karelia in the peace treaty.

Germany pressed Finland to join politically closer to the Axis powers. Finland was dependent on German armaments and grain. Moreover German armed forces were responsible for the defence of Lapland. Therefore, the Finnish government considered very carefully how far they could go. One possibility was to send volunteers to German international forces. The main stock of the Finnish officers, the Jaegers, had received their military training in the Imperial German army, and the Finns wanted to continue this tradition by joining the Wehrmacht. This was not possible. They had to content with a battalion in the SS-forces like all foreigners. The Finnish battalion fought on the Southern flank of Germany's Eastern front up to Caucasus. When the battalion was repatriated after two years' service in 1943, it was dispersed into different units of the Finnish army. Joining the Anti-Comintern Pact was also estimated possible because Finland already had defended herself against the Communist aggressor in the Winter War. ${ }^{16}$

\footnotetext{
16 See Mauno Jokipii, Panttipataljoona. Suomalaisen SS-pataljoonan historia [Battalion in Pledge. History of the Finish SS-Battalion] (Helsinki 1968).
} 
A separate military administration for the conquered Eastern Karelia was founded. In the hope of annexing the area finally to Finland the Russian minority was gathered to concentration camps, in order to be exchanged to the members of Fenno-Ugrian peoples in Russia after the war. They were no extermination camps, but when the war lasted much longer than expected and there was general lack of food in the country, about a third of the prisoners died of diseases and hunger. ${ }^{17}$ Finland and Germany practiced an exchange of prisoners of war, too. They were exchanged per capita and the Finns were interested to have Finno-Ugrians from the German camps in order to settle them in Eastern Karelia. The Germans correspondingly were interested in the Ukrainians and White Russians who were potentially cooperative but accepted Great Russians, too. There were some 2000 exchanges on both sides. The Finnish interest was derived more from kinship than racism. Some 70 Jewish prisoners-of-camp were delivered to Germans but not because they were Jews but hated political officers of the Red Army. Most Russian prisoners of Jewish origin were kept in Finland up to the end of war. ${ }^{18}$

When Germany could not defeat Russia before the end of the year 1941, Mannerheim started to doubt the victory. ${ }^{19}$ Most Finns still were in euphoria of their victorious battles and the warfare continued without greater offensives. The German disaster of Stalingrad and the allied demand of the unconditional capitulation caused anxiety in 1943. Great Britain had also declared war on Finland at the end of 1941, but it was not followed by military measures. The Finnish Government started to explore the possibilities of peace but it was difficult between the excessive Russian demands and the German opposition. The German occupation of Hungary in the spring of 1944 clearly showed the dangers of separatism. On the other hand the Germans kept continuing their deliveries of arms and grain despite of misgivings. Hitler was content with the letter of President Ryti where he

\footnotetext{
17 Antti Laine, Suur-Suomen kahdet kasvot. Siviiliväestön asema Suomen sotilashallinnossa 19411944 [The two Faces of Greater Finland. The Position of Civilians in the Finnish Military Administration 1941-1944] (Helsinki, 1982).

18 "Heikki Ylikankaan selvitys valtioneuvostolle" [The Account of Heikki Ylikangas to the Finnish Government], Valtioneuvoston kanslian julkaisusarja [The Publication of the Office of the Finnish Government] 5 (2004).

19 Tarkka, 59-60.
} 
vowed that Finland will not make peace under his presidency. ${ }^{20}$ Only after heavy fighting in summer 1944 did the Soviet Union drop her demand of unconditional surrender. It was high time to end the war in order to save the nation. President Ryti resigned and Mannerheim was elected President of Finland. He was free to make armistice.

The armistice was concluded on 19 September 1944. One of the conditions was that the Finns had to repel the German soldiers from Finland. The ending of the long German-Finnish comradeship of arms was not an easy task. The Finnish and German soldiers made an agreement to coordinate the German retreat and the Finnish attack. When the Russians soon discovered the common play, it had to be given up. ${ }^{21}$ Finland's rapprochement to NS-Germany ended in a war between them.

The armistice was at the same time a preliminary peace. Finland got mostly the same kind on peace conditions as after the Winter War. Instead of Cape Hanko the area of Porkkala, nearer to Helsinki, had to be rented as a military base. Finland had to give up the whole Petchenga and pay severe war reparations. In the Continuation war more 60500 Finnish soldiers were killed, altogether 90000 in the Second World War, The Finnish Karelians had again to leave their homes and to be settled in main Finland. ${ }^{22}$ Finland could not attain her grand national design, but the independence and pride of the country were saved. The final peace treaty was signed in Paris on February 10th, 1947 at the same time with the other co-belligerents of Germany.

\footnotetext{
20 See Markku Jokisipilä, Aseveljiä vai liittolaisia? Suomi, Saksan liittosopimusvaatimukset ja RytinRobbentropin sopimus [Comrades of Arms or Allies? Finland, German Demands of Treaty of Alliance and the Ryti-Ribbentrop Agreement] (Helsinki, 2004).

21 Tuomo Polvinen, Between East and West. Finland in International Politics, 1944-1947 (University of Minnesota Press, 1986), 37-54.

22 Martti Häikiö, "Jatkosodan ulkopolitiikka. Pitkospuita rauhaan" [The Foreign Policy of the Copntinuation War. Difficult Path to Peace], Jatkosodan pikkujättiläinen [The Concise History of the Continuation War], Toim/Eds. Jari Leskinen, Antti Juutilainen (Helsinki 2005).
} 


\section{References:}

"Heikki Ylikankaan selvitys valtioneuvostolle" [The Account of Heikki Ylikangas to the Finnish Government], Valtioneuvoston kanslian julkaisusarja [The Publication of the Office of the Finnish Government] 5 (2004).

Häikiö, Martti. "Jatkosodan ulkopolitiikka. Pitkospuita rauhaan" [The Foreign Policy of the Copntinuation War. Difficult Path to Peace], Jatkosodan pikkujättiläinen [The Concise History of the Continuation War]. Toim/Eds. Jari Leskinen, Antti Juutilainen. Helsinki 2005.

Hovi, Kalervo. "Göring ja Talvesõda" [Göring and the Finnish Winter War], Tuna 1 (2006).

Jokipii, Mauno. Jatkosodan synty. Tutkimuksia Saksan ja Suomen sotilaallisesta yhteistyöstä 1940-41 [Emergence of the Continuation War. Researches of the German and Finnish Military Cooperation 1940-41]. Helsinki, 1987.

Jokipii, Mauno. Panttipataljoona. Suomalaisen SS-pataljoonan historia [Battalion in Jokisipilä, Markku. Aseveljiä vai liittolaisia? Suomi, Saksan liittosopimusvaatimukset ja Rytin-Robbentropin sopimus [Comrades of Arms or Allies? Finland, German Demands of Treaty of Alliance and the Ryti-Ribbentrop Agreement]. Helsinki, 2004.

Jussila, Osmo. Terijoen hallitus 1939-1940 [The Terijoki Gióvernment, 19391940]. Helsinki, 1985.

Laaksonen, Lasse. "Kannaksen taistelut" [Combats on the Karelian Isthmus], Talvisodan pikkujättiläinen [Concise History of the Winter War]. Eds. Rari Leslien and Antti Juutilainen. Helsinki 1999, 435-453.

Laine, Antti. Suur-Suomen kahdet kasvot. Siviiliväestön asema Suomen sotilashallinnossa 1941-1944 [The two Faces of Greater Finland. The Position of Civilians in the Finnish Military Administration 19411944]. Helsinki, 1982.

Nevakivi, Jukka. Appeal that was never Made, Allies, Scandinavia and the Finnish Winter War 1939-1940. London, 1976.

Parrtanen, Jukka. Manerheim ja Hitler [Mannerhein and Hitler]. Helsinki, 2012. Peltovuori, Risto O. Saksa ja Suomen talvisota [Germany and the Finnish Winter War]. Helsinki 1985.

Pledge. History of the Finish SS-Battalion]. Helsinki 1968.

Polvinen, Tuomo. Between East and West. Finland in International Politics, 19441947. University of Minnesota Press, 1986.

Rautkallio, Hannu. Suomen juutalaisten aseveljeys [The Comradeship of arms of the Finnish Jews]. Helsinki, 1989.

Tarkka, Jukka. Neither Stalin nor Hitler. Finland during the Second World War. Transl. by David Mitchel. Helsinki, 1991. 
Turtola, Martti. "Katkera rauha ja Suomen ulkopoliittinen asema" [The Bitter Peace and the position of Finnish foreign policy]. In Talvisodan pikkujättiäinen [The Concise History of the Winter War]. Toim/ Eds. Jari Leskinen, Antti Juutilainen. Helsinki, 1999.

Ueberschär, Gerd R. Hitler und Finnland 1939-1941. Die deutsch-finnischen Beziehungen während des Hitler-Stalin-Paktes. Wiesbaden: Frankfurter Historische Abhandlungen 16, 1978.

Ylikangas, Heikki. "Saksa ja Suomi talvisodasta välirauhaan” [Germany and Finland from the Winter war to the Interim peace]. In Heikki Ylikangas, Tulkintani talvisodasta [My interpretation of the Winter War]. Helsinki, 2000. 
Online:

\title{
DOUNG PEOPLE FROM BOSNIA AND HERZEGOVINA IN NORWAY: MIGRATION, IDENTITY AND \\ ETHNICITY
}

Dragana Kovacevic

University of Oslo, E-Mail: dragana.kovacevic@ilos.uio.no

\section{Acknowledgments}

This paper has been presented at the Third International Conference on Nordic and Baltic Studies in Romania: European Networks: the Balkans, Scandinavia and the Baltic World in a Time of Crisis hosted by the Romanian Association for Baltic and Nordic Studies and Valahia University of Târgoviste, and sponsored by the Romanian National Research Council, May 25-27, 2012.

\begin{abstract}
:
The article focuses on young people originating from Bosnia and Herzegovina, permanently residing in Norway, who first came to Norway as children and conflict refugees in the 1990s. It investigates how they relate to their identity and origin, and how they discursively represent nationalism(s) and wars in the sending society. It also discusses their integration into Norwegian society and poses a question how ethnicity is contextualized in a receiving society in which it is generally socially desirable to express values of tolerance and respect for multiculturalism. Material from the interviews with young Bosnians and the participant observation of relevant events makes it possible to reflect on such phenomena as transnational belongings and the so-called long-distance nationalism, leading to the discussion about the contested claims of victimhood in the post- Yugoslav immigration context.
\end{abstract}

\section{Rezumat:}

Lucrarea se concentrează asupra tinerilor care provin din Bosnia și Herțegovina, cu reședința permanentă $\hat{\imath}$ Norvegia, care au venit $\hat{\imath}$ primul rând $\hat{\imath}$ această $t$ ară țară în calitate de copii și refugiați ai conflictelor din anii '90. Aceasta investighează modul în care aceştia se raportează la identitatea și originea lor, precum și felul $\hat{\imath}$ care reprezintă discursiv naționalismul (naționalismele) și războaiele din societatea din care provin. Este abordată, de asemenea, integrarea lor în societatea norvegiană și este observată modalitatea în care identitatea este contextualizată într-o societate primitoare in care acesta este $\hat{i n}$ general de dorit a fi exprimate $\hat{i}$ cadrul social valori de toleranță și de respect pentru 
multiculturalism. Materialul din interviurile cu tineri bosniaci și observația participativă a evenimentelor relevante permit să se reflecteze asupra unor fenomene cum ar fi identitățile transnaționale și așa-numitul naționalism de distanțe lungi, ceea ce aduce în discuţie postura disputată de victimă în contextul imigrației post-iugoslave.

Keywords: Ethnicity, Identity, Long-distance Nationalism and Migration

Thesnia and Herzegovina lasted from 1992-1995 and
caused the largest refugee crisis in Europe since the
Second World War. Bloody ethnic conflict and ethnic cleansing campaigns drove hundreds of thousands of people out of their homes and forced them to look for a refuge both within the borders of their country and abroad, in other countries that were willing to accept them, whether on temporary or permanent bases. Norway was one of the countries that offered protection to Bosnian refugees during the war and in its aftermath. What makes the case of Bosnian refugees in Norway particularly interesting is the fact that this country, unlike many others, very soon after their arrival included Bosnian war refugees in various integration programs and offered the majority of them the possibility to stay in the country permanently. ${ }^{1}$

According to different sources the total estimated number of people with Bosnian origin in Norway is around 15,000, and the majority of the Bosnians residing in Norway are of Bosnian Muslim (Bosniak) origin, but there are also some Bosnian Serbs, Bosnian Croats and people from mixed marriages who were often the ones who needed to seek refuge outside of the country of origin. Quite often the ones who are willing to identify and call themselves Bosnians ${ }^{2}$ are people of Bosniak and possibly mixed origin,

\footnotetext{
1 See Marko Valenta and Sabrina P. Ramet, The Bosnian Diaspora: Integration in Transnational Communities (Farnham, Surrey, England: Ashgate, 2011). This observation only holds water for those Bosnian refugees who arrived during the war and in its aftermath. Later Norwegian asylum politics was much stricter and less accepting: for example, refugees from the Kosovo conflict did not receive the same kind of treatment in 1998 and 1999 as people from Bosnia did earlier in the same decade, a majority of them was ordered to return to their country upon the end of the armed conflicts.

2 In Norwegian language, bosnier translates as Bosnian and bosniaker means Bosniak, but the terms are quite often mixed and confused in Norway. 
while in many cases Serbs and Croats from Bosnia see themselves as parts of Serbian and Croat community and avoid calling themselves "bosniere" in the Norwegian context according to a widespread understanding of the word in this context. However, in former Yugoslavia this term typically referred to geographical origin and it did not bear an ethnic overtone. Abroad the term is often associated and confused with the term Bosniak.

While the majority of Norwegian Bosnians is at least culturally Muslim (Bosniak), as well as some of the most stigmatized and popularly considered as "hard to integrate" groups whose affiliation to Islam is often popularly perceived as one of the main obstacles for integration, this seems not to be the case for the white European Bosniaks. According to both the results of numerous surveys and research projects and popular beliefs, Bosnians in Norway are among the most successfully integrated groups and a shiny example of "good immigrants" and citizens. According to Valenta and Strabac ${ }^{3}$, they have successfully redefined themselves from poor asylum seekers to successful citizens of Norway, thanks primarily to the official policy of Norway that had them scattered all around the country to settle. As previously noted, most of them had no difficulties in resolving their status, as they were accepted based on special care for refugees.

My research is designed in such way that it focuses on a particular "inter-generation" of people, namely a generation that some sources denote as "one-and-a-half" generation of immigrants. I am interested in identifications of young people who originate from the territory of Bosnia and Herzegovina and who were actually born back in that sending society ${ }^{4}$, however, they cannot truly be considered the first generation of immigrants, as they moved to Norway as minors, together with their parents. I found that this focus group makes for an especially interesting case to study such phenomena as integration, transnational belongings and the so-called long-distance nationalism. ${ }^{5}$ Being educated and socialized in the host society, this generation could be expected to express tolerance and respect for multiculturalism much more than their parents' generation might. However, they are refugees from a horrible war, and this along with

\footnotetext{
${ }^{3}$ Valenta and Ramet.

4 Thereby they technically cannot be denoted as second generation migrants.

5 Benedict R. Anderson, Long-Distance Nationalism: World Capitalism and the Rise of Identity Politics (Amsterdam: Centre for Asian Studies Amsterdam, 1992).
} 
the fact that they were exposed to their parents' opinions, attitudes and memories while growing up can potentially turn them into more or less long-distance nationalists who might repeat and revive the essentializing agendas transplanted from the sending society through their childhood homes. Also, although they are part of a group that is popularly considered as well integrated, they often are still aware of their "foreignness" and the fact that they are immigrants who, probably, as put by many of my informants, "can never be really Norwegian" which also could be one of the triggers for the long-distance nationalism and the fact that a vast number of the people I got to talk to consider Bosnia a "real home" although often they speak Norwegian much more advanced than Bosnian.

In addition to all these research dilemmas, for my study the important question in the post-Yugoslav context is what their relations to "other" ethnics from the same area are, whether problematic and conflictbearing interethnic relations from back home are reproduced in the new host society and how memory is used to reconstruct history. The discursive representations of the wars in former Yugoslavia will be examined in light of this extremely violent ethnically framed conflict, but also in relation to personal immigration experiences and growing up in Norway. A very significant percentage of young people in Norway born from Bosnian parents take up higher education. There can be found evidence of them scoring higher even than ethnic Norwegians in this regard ${ }^{6}$. For all these reasons, young, often highly educated and well integrated young Bosnians are an interesting focus group to reflect on ethnic identity and immigrant nationalism and the fact that, as put by Glick Schiller, in many instances, transmigrants are acting in ways that reinforce but reconfigure the institutions and nationalist ideologies of migrant-sending countries ${ }^{7}$.

This paper reflects on findings and experiences from my fieldwork in Oslo, and the method of participant observation is supplemented with in-depth interviews with so far ten young people, in order to investigate how individuals perform their identities. Fieldwork findings are followed up with narrative analyses of media and social media discourse that are in a crucial way connected to Bosnians in Norway. I engaged in participant observation of informal gatherings of young Bosnians, events of the youth

\footnotetext{
${ }^{6}$ see Valenta and Rammet, 88

7 N. Glick Schiller, Migration, Development, and Transnationalization: A Critical Stance (New York: Berghahn Books, 2010). 
Bosnian organization founded at the University of Oslo, as well as lectures at a course at the University of Oslo that deals with the break-up of Yugoslavia and it is regularly attended by young people originating from the region. I also used newspaper articles and online sources that I found relevant for my subject, and repeatedly visited online groups formed and commented by Bosnians living in Norway, related to a special and interesting case that I will write about in more details in one of the final paragraphs of this article: I will present and discuss reactions that followed the screening of a documentary about the Srebrenica genocide on Norwegian national TV channel in April 2011 and the victim-centered discourse as a rather important part of self-representation of this particular refugee group.

In the conclusion I will relate my hitherto collected findings with the theories about transnationalism and long distance nationalism, and proceed with the discussion of the possible hypotheses for the desirability of the victim image.

Besides integration patterns and the number of immigrants, reasons for focusing on people origination from this country in my research were numerous: it was the site of the most violent and destructive conflict of all the conflict sites in the former Yugoslavia. Importantly for this project and the discussion of long-distance nationalism, there are serious challenges to the maintenance of the unity of this country to this day, due especially to the tensions between two separate ethnically divided entities established by the 1995 Dayton Peace Agreement. Territorial unity is perceived as a constant challenge and a very special situation. ${ }^{8}$ The threat lies in the wish of presumably most of people in the Serbian entity to secede. A large number of the Bosnian Serbs themselves perceive the situation as unsolved as well, as Republika Srpska is not an independent state they strive towards. As an additional complication, when it comes to the Croats, the third largest ethnic group in this country, the more nationalist members of this community would either advocate for the existence of a separate Croatian entity as the third one, or, in the most extreme right nationalist

\footnotetext{
8 I would in future be interested to explore whether increased transnational engagements of a diaspora stand in direct correlation with an "unfinished" nature of a national political project. Arguably this contributes to patriotic feelings and engagements of the diaspora. For this a good comparison would be Tamil refugees all over the world today, but also the Zionist project prior to the establishment of the state of Israel.
} 
dreams, propagate a complete independency of "Herzeg-Bosna" 9 and even its union with Croatia.

For the part of this article based on interviews, opinions of young people who see themselves as non-nationalists (although some of them did clearly and openly declare as Bosnian patriots), are taken into consideration. ${ }^{10}$ They have university education and make high use of modern technologies in their everyday life and very much so for their transnational practices. In the course of the interview they typically exhibit a high level of awareness of what is seen as politically correct, and view nationalism (defined as chauvinism) as a bad thing.

The almost unanimous immediate answer to the question what homeland is was typically Bosnia and Herzegovina, however, patriotic discourse was appropriated so that it excludes nationalistic outbursts, hatred and open ethnic distance. Some expressions of the ethnic prejudice do come up, but often and typically mentioned when talking about how some others view things. ${ }^{11}$ That would seemingly go in line with Vertovec's claim that transnationalism leads to abandoning the myth of homogeneous and mono-cultural nation state. However, I would argue how in many cases transnational practices keep this myth alive and turn to be reaffirmations of ethnically based ideologies of a sending state.

A young woman I interviewed, one of the most actively engaged members of the Bosnian youth organization founded at the University of Oslo, stated how all the statistics show how well the Bosnians are integrated, but she continued by saying: "We have already proven that we are good Norwegians. Now let's try to at the same time be good Bosnians." She felt that Bosnian youth is so well integrated that they become easily assimilated (which is viewed as a negative development) and do not know

\footnotetext{
9 A highly charged name that Croatian far right uses to refer to what they see as Croatian Bosnia.

10 An important note for the future research and for reading of the results presented here is that by far the most numerous and influential Bosnian organization in Norway is the Islamic Union of Bosniaks in Norway, whose young member I still have not had the chance to talk to, but I do intend to do so. Because of the organizations presumably strong and exclusive religious and ethnic affiliations, it might very well be the case that opinions they would express are much less tolerant and politically correct than attitudes of young secular and liberal people I had the chance to talk to, but I cannot be sure of it at this stage of my research.

11 Often their parents or relatives.
} 
the basic things about the homeland.12 She repeatedly said how she was a proud Bosnian, but the term ethnicity had a very bad sound for her because of the ethnic war in Bosnia. Although she came from a Muslim family and saw herself as a believer (although not practicing Islam in a strict manner) she stated how she is a Bosnian, not a Bosniak. She disliked this latter term and found it exclusive and artificial. In her view, an Orthodox (Serbian) friend from her hometown is no less Bosnian than she is, both having a long line of ancestors in Bosnia. But she feels that often Bosnian Serbs refuse to accept Bosnia as their homeland, which is a shame ${ }^{13}$. The informant mentioned how her parents do not share her tolerant views and how she was often told "not ever to trust a Serb". She expressed understanding for their suspiciousness by mentioning a concrete example of her mother's friend whom they heard committed crimes against Bosniaks during the war. This friend contacted the informant's mother after the war and claimed those accusations were not true, but the mother did not believe it and remained convinced this is just one more example of why Muslims never should trust the Serbs again. The interviewee, however, stated how she does know and befriend people of Serbian and other Yugoslav ethnic backgrounds "here" in Norway. She was not the only informant to state that the parents are both less integrated and less open and tolerant then the young people are. The parents typically have less contact with the Norwegian host society, and faced with forced displacement they were challenged to renegotiate their identities in a much different way than their at the time underage children.

But a renegotiation of identities is constantly enacted, especially in the case of immigrants, and nationality can be recombined, concealed or displayed as it was put by Vertovec. ${ }^{14}$ People "under-communicate" what

\footnotetext{
12 She feels there are too many "too Norwegian" young Bosnians, they "dye their hair blonde, have only Norwegian friends". I so far have not run across an informant that could fit this description (possibly because of the snowballing method), except possibly one young girl scheduled to be interviewed in spring 2012, who comes from a mixed background. However, she also speaks perfect BCMS and I cannot be sure how she herself feels and identifies before talking to her.

13 An example of conflicting identities she mentioned was the tension between "Bosanci" and "Hercegovci", saying that conflicts and even violent fights happen between them in Norway. On her side, every time she mentioned Bosnia she would use the whole term Bosnia and Herzegovina. Consistent insistence on the full term clearly shows her desire for the unity and "wholeness" of her homeland.

14 Vertovec 2010, 12.
} 
they feel they need to and communicate what they choose to. Asked about whether they are in any way affected by public and media anti-Islamic discourse after 9/11, many people I talked to responded negatively, with more or less the same explanation: No one sees I am a Muslim. I talk like a Norwegian. I am white. I am not visibly Muslim. I never publicly display my religious affiliation. But people do insist on certain national identities when they decide it is time or place to do so: I don't want to be fully assimilated. I want to be a good Bosnian. I want to do something for Bosnia. I can never really be Norwegian. Bosnia and Herzegovina is my real homeland. I am proud to be a Bosnian ${ }^{15}$. Immigrants walk these lines while being aware of different cultures because they found themselves on the boundaries of it ${ }^{16}$. In this case, young immigrants calculate and negotiate the fact that they are able to blend in much more than some other immigrant groups. ${ }^{17}$

A very active and influential youth association was founded in 2007 by young Bosnians studying at the University of Oslo. As they say: "The aim of this association is, among other things, to create a bond between young Bosnians in Norway, strengthen the multicultural and multi-ethnical Bosnian identity, strengthen the bond between Bosnians in Norway and their native country, nurture the Bosnian tradition, customs, language and culture among Bosnians in Norway, strive for activity and motion among young Bosnians. "18 A number of the events they organized, although most often held in Oslo, dealt with political and social issues in the homeland. Their current main project is physically located in Bosnia ${ }^{19}$. Organization has an aim to raise awareness in diaspora about what is going on home and help them realize how they can help from their own position, as citizens of one of the richest countries in the world. They claim to be proud Bosnians and Herzegovinians although satisfied with life in Norway and trying to pick up the best of both cultures, in words of one of them, "open to the other, but taking care of your own". "Their own" is in this case ideally seen

15 These are not literal quotes of their words, but my own retelling of the pattern of their responds.

16 See T.H. Eriksen, Small Places, Large Issues: An Introduction to Social and Cultural Anthropology (London: Pluto Press, 2010).

17 One young Bosnian men said to me: "A regular Norwegian gets his or her picture from news about men with beard and women that are covered. It is about the way one looks." Gellner spoke of entropy resistant traits, distinguishing marks of the minority that cannot be removed whether the members wish so or not. (Eriksen 2010, 285.)

18 http://www.uio.no/english/student-life/societies/international/e_stecak.html

19 Free legal aid for people in one municipality in Bosnia, supported by Norwegian funds. 
as Bosnian without ethnic divisions. ${ }^{20}$ They feel like that being engaged to help the homeland is a socially responsible thing to do, and opting for complete "Norwegianness" and assimilation is something people involved in this project would pass a moral judgment on. Some of them feel like this kind of active engagement is a sort of a solution for their position between the two worlds. But they generally want to stay and live in Norway. ${ }^{21}$

Adrian Farwel noted how immigrants, who are between two or more cultures, are also good indicators of power to be found by playing on the line between belonging and non-belonging. Although being "a Bosnian in Norway, and a Norwegian in Bosnia" is a disruption and a tense and stressful existential position, it has its advantages in terms of networking and belonging. In line with that goes the fact that interviewees were typically happy and proud to claim that Bosnians are among the most integrated immigrant groups in Norway. More if them stated there is no such thing as a Bosnian ghetto in Oslo or any other city where they live grouped, in difference to some other groups of immigrants who do express that kind of behavior, and they considered the lack of that as a positive thing. They saw themselves as integrated and acculturated ${ }^{22}$, but still Bosnian and stating the need for the Bosnian community in Norway to be better organized and connected, in order to help the homeland. What is the social capital that they would expect out of it was not clearly stated, however, we may guess that is partly so because they feel they cannot be "really" Norwegian. As the majority has political power, that might explain the increased interest in a state where they are not a minority, which partly shows how essentializing views of national identities are still dominant in the everyday life of many people.

One of the interviewees claimed he was lucky because he grew up in a little town, surrounded by mostly Norwegian counterparts, so he learned the language easily and fluently. He thinks it is impediment to integration if you end up in a city like Oslo, and create such a ghetto where

\footnotetext{
20 Aftenposten, the largest Norwegian daily, published a centerpiece interview with three young leaders of Stećak 29 May 2011 and it was emphasized how they refuse to say which of the ethnic groups in Bosnia they themselves belong to, and refuse to ask the others about it, as they find it wrong and uncomfortable to do so.

21 "It (Bosnia and Herzegovina) will always be my homeland, but my home will be Norway." said one young man in the interview.

${ }^{22}$ Quite often it was obvious to me that they think in Norwegian and translate it into Bosnian as they speak, based on construction of certain sentences.
} 
only foreigners live. However, another informant stated she was exposed to racism and discrimination growing up in a little town, but not once she moved to Oslo. She claimed that because of the fact that she finished elementary school in a little town in Norway, high school in Bosnia and again university in Oslo, she had to face different kinds of discrimination ${ }^{23}$ : in her own words, she experienced the racism of Norwegian kids in the little town, but the help and care of teachers who tried to prevent that. In Bosnia, it was exactly the opposite. Her high school teachers were the ones targeting her (she felt) as someone who came back to Bosnia from Europe, making her ashamed she does not speak and read Bosnian well enough. After moving to Oslo to study, she claims not to have experienced any discrimination anymore.

It was often stated by my young informants how parents usually had plans and ideas of returning to Bosnia as soon as possible when they first came to Norway (perhaps due to their official status as permanent refugees at the time, but according to many testimonies, also due to their genuine wishes to go home), and often much longer than just during the first period, until they finally realized it might not be possible, due to many reasons and, not rarely, economic ones.24. Young and integrated people would typically see Norway as a more open and tolerant society than Bosnia and Herzegovina, which they perceive as a really good thing, and seem sorry or sometimes even embarrassed to state how their parents are much less open to differences than they are. One informant said how unlike him, parents socialize neither really with Norwegians, nor with the Balkan "others", or if and when so, only superficially and being extra careful not to mention anything possibly inflammatory and "nationally inclined", as he said, knowing in advance some others would strongly disagree. Such subjects are avoided in a direct personal contact. To illustrate the perception of a serious generational gap, during a seminar about position of women and youth in Bosnia organized by the youth organization I observed, that included panelists such as a minister and journalists from

\footnotetext{
23 Discrimination, of course, is one of the most serious impediments to a successful integration of a group.

${ }^{24}$ In only one of the cases did parents of an informant actually return, and that is in the aforementioned case of the young lady came back alone after five years of high school in Bosnia. 
Bosnia and the Bosnian ambassador in Norway, several older people turned the part of panel discussion open to questions from the audience into war stories and accusations. Young organizers were at first glad a lot of older generation Bosnians came (the comments I heard from them prior to the start of the seminar, while the audience was still arriving), but as the discussion turned to war and to expressions of intolerant views, they appeared to be, in later conversations with me, ashamed of that how "they" (the older ones) can never "let go": "You see? This always happens! They always end up talking this way", said one of the young organizers to me after the end of the formal part of the seminar.

The issue of what it means to be Bosnian, who "our" people and who the "others" are is even more complicated than earlier sketched. It is impossible not to consider multiple inter-ethnic tensions and war legacy. Many Bosnian organizations and individuals reacted strongly against a documentary about Srebrenica genocide shown in April 2011 on the Norwegian public TV station, NRK. The documentary was titled "Byen som kunne ofres" (City that could have been sacrificed). Dissatisfaction with this movie came out of the fact that indicated and implied that Bosniak wartime leadership holds a part of responsibility for the genocide in Srebrenica and the fact that the documentary continuously referred to the war crimes in Serbian villages surrounding Srebrenica prior to the actual genocide when Serbian army entered the city. This all provoked protests from numerous Bosnian and Bosniak organizations, including the youth organization I observed, in particular, at the Islamic Union of Bosniaks in Norway reactions in the social media and in the Bosnian Post magazine(a main printed medium of Bosnians in Scandinavia), and also the protest note by the Embassy of Bosnia and Herzegovina in Oslo. The most often repeated argument was that NRK falsifies the truth in an attempt to present victims as perpetrators. This victim centered discourse is of particularly interested in this paper, since it is used in a central way in all the three main ethnic discourses relating to the war Bosnia and Herzegovina, but also in wider Yugoslav context. ${ }^{25}$ In this case study it will

25 The central point of Serbian nationalistic discourse lies in the claims that Serbs are wrongfully accused by the Western media of being the main perpetrators. Central point of Kosovo Albanian nationalist discourse involves strong insistences on the victim position, as 
be discussed how such discourse is appropriated by many people from Bosnia who are settled in in Norway.

Two facebook groups ${ }^{26}$ I often visited in June and July 2011 to follow the discussions about this documentary are called: "'Byen som kunne ofres', najsonal skam for Norge" ('City that could have been sacrificed', a national shame for Norway) and "Bosniere mot NRK", (Bosnians against the NRK). Both groups have titles in Norwegian and posts are predominantly either in Norwegian or in Bosnian language. ${ }^{27}$ The main theme taken up by those leaving the posts was the unfairness and scandalous nature of this documentary, anger directed against the NRK and what the members often called the "Stoltenberg" 28 clan, perceived as pro-Serbian. The arrest of the general Ratko Mladic, the main culprit for the genocide in Srebrenica happened shortly after the screening of the documentary, in May 2011. This understandably ended up being the second most important topic in a lot of the posts and comments. Some members, especially in the second group, use very harsh language and even hate speech. Typically they were not censored and comments seemed not to be erased. However, I concluded that the main strategy behind these reactions is advocating for views of "the truth of what happened", mostly and interestingly in Norwegian, as often posts were in Norwegian and calling upon Norwegian people to realize who is right and who "the real victim" is, with a lot of concrete proposition for what could be done in order to achieve this.

This film provoked such strong reactions as it presumably jeopardized the desired and for a long time secured "victim" position.

\footnotetext{
it is in the Bosniak and Croat ones. These discourses are contested and completely mutually exclusive in the views of those who propagate such views.

${ }^{26}$ Of course not all of the members are young, but the administrators seem to be, as well as a lot of the members, whose statements I analyzed.

27 "Disse dokumentarene som er laget av NRK er ren serbisk propaganda og fulle av feil og løgn. Ove dokumentarce sto je napravila norveska drzavna televizija je cista srpska propaganda i puni su gresaka i srpski lazi!!!!!!!!!!» Translation : These documentaries made by NRK are a pure Serbian propaganda and full of mistakes and (Serbian) lies https:/ / www.facebook.com/pages/Bosniere-mot-NRK-Svi-sto-smo-protiv-NRKalle-somer-imot-NRK/198429010194447 Accessed 09.10.2011.

28 The current prime minister of Norway, Jens Stoltenberg, is the son of famous Torvald Stoltenberg who was one of the mediators and negotiators during the wars in former Yugoslavia. Certain discourses present him as pro Serbian and anti-muslim, due partly to the fact that he lived in Belgrade and served as an ambassador of Norway during the times of Tito's Yugoslavia.
}

80 
Being produced and shown on the public national TV station in Norway, the possible influence and perception of it was judged as serious and dangerous. Language and arguments used in the official reactions of organizations such as Stećak was of course much more correct and rational than the ones expressed by some individuals leaving posts on Facebook groups. However, that decent discourse, as mentioned, also explicitly complained about the confusion between who a victim and who a perpetrator is, in such a way that it identified these roles with ethnic groups.

One of the post reads: "I invite all the citizens of Bosnia and Herzegovina who live in Norway, who have survived Serbian torture and lost their dearest ones, to create a front and sue the serbs and the so-called serb republic (I intentionally write with small letters) and ask for war reparations. The main purpose is not money, it is the evidence of their crimes. Then let's see if NRK will support us..." 29

And another one says:

"This is a shame that a national TV from a country that accepted so many Bosnian refugees shows such lies, haven't they so far realized who the serbs are and what they are capable of doing. Shame." 30

In important ways the analysis of reactions to this documentary provided the possible hypothesis for one of the main questions I posed in the proposal for my overall research: Why are "branding" and a positive national image so important to the individuals who feel they belong to a certain nation, and what discursive strategies are used in order to achieve this goal? As immigrants, subjects are frequently tagged as "foreigners;" therefore, references to their ethnic origins are directly connected with their self-image. In this sense, "othering" may rather be a byproduct of building a positive group image, than of self-definition of "groupness" against the relevant others. The battle over "who is right" is partly related to having a more positive group image within the host culture, especially in cultures where ideas of human rights, tolerance, democracy etc. are

\footnotetext{
${ }^{29}$ Original in Bosnian: “Pozivam sve gradjane BiH koji zive u Norveskoj, koji su preziveli srpsku torturu i izgubili svoje najmilije da stvorimo front i tuzimo srbe i takozvanu republiku srpsku (pisem namjerno malim slovima) i trazimo odstetu... Glavni cilj nije novac ali jeste dokaz njihovih zlocina. Pa da vidimo hoce li nas NRK podrzati..."

30 Ovo je sramota da jedna drzavna televizija iz zemlje koja je primila toliko izbjeglica iz Bosne i Hercegovine prikazuje ovakve lazi, zar dosad nisu shvatili ko su srbi i sta su u stanju uciniti. Sramota.
} 
considered to be held at a premium. Positive group image seems to be connected with the access to material and social capital, and access to "European-ness" and "Norwegian-ness" can be seen as a finite resource: only those who have been "victimized" in the past, have the right to these positions in Norwegian society.

\section{Conclusions}

Attitudes and engagements of young people included in this observation present an example of social and political engagement aimed at presenting one political and social agenda, reproducing beliefs and political goals, as well as identifications clearly derived and inherited from the Bosnian context. It involves engagement in a very special Norwegian situation and settings, but almost exclusively from the point of view of being a Bosnian. If a victim position is challenged and contested, too much ends up being at stake, identity-wise. Being one of the refugees that got a special treatment and a welcome into their new country possibly exactly because of them being perceived as victims, contestations of this position challenge both their group position and their individual identifications and worldviews. "Transmigrants are immigrants who live their lives across national borders, participating in the daily life and political processes of two or more national states" (Glick Schiller, 1997, p. 155).

As Hylland Erikssen wrote, the world of transmigrants encompasses more than one national structure, however, it may develop into a particular form of nationalism, long-distance nationalism or patriotism. "The fact of migration in an era of fast communication thus also paves the way for long-distance nationalism (Anderson 1992) whereby the political scene in a given territory may be partly shaped by the agency of migrants (Eriksen, 2010, p. 306) 31 . In this sense, more than being a challenge for essentializing identities, transnational belongings and practices end up reaffirming the essentializing identities and reproduce the homogenizing agendas of the sending society. Transnational practices are clearly influenced by transmigrant's feelings of belonging and often even crucially by ethnic identifications and belongings.

However, as migrants, according to Eriksen, live in the two worlds and switch between cultural codes, people often learn to express their

\footnotetext{
${ }^{31}$ He gives the example of Tamil refugees in Norway, saying how the main concern of many of them is not integration, but supporting the separatists movement in Sri Lanka.

82
} 
belongings and attitudes in accordance with the generally accepted cultural code of the host society in, at least in situations when they are personally and directly held accountable for their own words ${ }^{32}$. It is my view that in the context of Norway, patriotism is a highly acceptable sentiment, while fierce nationalism and the expression of inter-ethnic prejudice are not. This might influence the formulations and discourse as presented in this research, to the extent where it might be more appropriate to talk about long-distance patriotism than long-distance nationalism from the point of you of the subjects included in this study/observation. The reason for this is twofold: One, Bosnian identity is, at least declaratively, inclusive and non-ethnic, and the very choice of such identification, although in some cases it might be just a cover term for the promotion of Bosniak ethnic nationalism ${ }^{33}$, often genuinely stands for one's belief in the multicultural and multiethnic past and future of Bosnia.

\footnotetext{
32 Which might partly explain the harsh language used in the anonymity of an online context, although Facebook posts is not necessarily anonymous and often the names and pictures are genuine, it still seems that people generally express their prejudices much more open in such a setting than in an everyday conversations.

33 Especially in the migration context, as a lot of people in other countries do not really distinguish and understand Yugoslav differentiations between highly politically charged terms such as: Bosniak, Bosnian, Bosnian Muslim, and Muslim. For Norwegians and others Bosnian often stands for what Yugoslavs would call Bosnian or a Muslim; being aware of this fact, even a Bosniak immigrant of nationalistic convictions might still perpetuate and promote such identifications in accordance with a Bosniak nationalistic agenda, while a nationalistic Serb from Bosnia would typically make sure to explain that not all people in Bosnia are Bosniaks.
} 


\section{References}

Anderson, Benedict R. Long-Distance Nationalism: World Capitalism and the Rise of Identity Politics. Amsterdam: Centre for Asian Studies Amsterdam, 1992.

Brubaker, R. Ethnicity without Groups. Harvard University Press, 2004.

Eriksen, T.H. Ethnic Identity, National Identity, and Intergroup Conflict, The Significance of Personal Experiences. In Social Identity, Intergroup Conflict and Conflict Reduction. Eds. Richard D. Ashmot et al. Oxford University Press, 2001.

Eriksen, T.H. Ethnicity and Nationalism, London: Pluto Press, 2002.

Eriksen, T.H. "Nationalism and Internet." In Nations and Nationalism. 13, No. 1 (2007): 1-17.

Eriksen, T.H. Small Places, Large Issues: An Introduction to Social and Cultural Anthropology. London: Pluto Press, 2010.

Fairclough, N and Ruth Wodak. "Critical Discourse Analysis." In Discourse as Social Interaction. Ed. Teun Van Dijk. London: SAGE Publications, 1997.

Fuglerud, $\varnothing$. Life on the Outside. Tha Tamil Diaspora and Long Distance Nationalism. London: Pluto Press, 1999.

Glick Schiller, N. "From Immigrant to Transmigrant: Theorizing Transnational Migration," Anthropological Quaterly 68, No.1 (Jan. 1995): 4863

Glick Schiller, N. "The Situation of Transnational Studies." In Identities 4, No. 2 (1997): 155-166

Glick Schiller, N. et al.. Towards a Transnational Perspective on Migration. Race, Class, Ethnicity, and Nationalism Reconsidered. New York: The New York Academy of Sciences, 1992.

Glick Schiller, N. et al. Migration, Development, and Transnationalization: A Critical Stance. New York: Berghahn Books, 2010.

Grillo, R.D. "Transmigration and Cultural Diversity in the Construction of Europe", http://www.europadiversa.org/eng/pdf/ponencia_grillo_eng.doc (2000), accessed 14.02.2011.

Guarnizo,L.E. and Michael Peter Smith. "The Locations of Transnationalism" in Transnationalism from Below. Eds. Michael Peter Smith 
and Luis Eduardo Guarnizo. New Brunswick: Transaction Publishers, 1998.

Guiberno, Montserrat and John Rex. The Ethnicity Reader; Nationalism, Multiculturalism and Migration, Cambridge: Polity Press, 2010.

Kostoiu, A. "Modes of Minorities' Integration: Explaining Historical, Economic and Political Factors." Journal of Identity and Migration Studies 2, No. 2 (2008).

Valenta, Marko, and Sabrina P. Ramet. The Bosnian Diaspora: Integration in Transnational Communities. Farnham, Surrey, England: Ashgate, 2011.

Van Dijk, T.A. Communicating Racism. Ethnic Prejudice in Taught and Talk. Newbury Park: Sage Publications, 1987.

Vertovec, S. "Transnational Challenges to the 'New' Multiculturalism", paper presented to the ASA Conference held at the University of Sussex, 30 March - 2 April 2001.

Wodak, R. et al. The Discursive Construction of National Identity. Edinburgh: Edinburgh University Press, 1999. 


\title{
T NTERNATIONAL REACTIONS TO THE RUSSIAN SUPPRESSION OF THE POLISH INSURRECTION (NOVEMBER 1830)
}

\author{
Veniamin Ciobanu \\ “A. D. Xenopol" Institute of History \\ E-mail: veniamin@xenopol.iasi.astral.ro
}

\begin{abstract}
:
The outburst of the Polish insurrection and its evolution attracted the attention of the European Powers, due to the international political context in which it started, that of the liberal-bourgeois revolutions in France, Belgium, Germany, Italy, Spain, Portugal, and of the implications that were expected to occur due to power balance on the continent and in the Eastern Question. Russia's position in the political systems mentioned above depended on how the Polish Question would be solved. By subordinating all the Kingdom of Poland, whose political individuality, in the Russian political and institutional system, in which the decisions of the "Final Act" of the Peace Congress in Vienna (June 9th 1815) placed it, was about to be abolished by the Tsar, opened to the Russian Empire the path towards the consolidation of its positions in the Baltic region, strategically, political an economical, thus upsetting the other Powers in the European political system, on one hand. And secondly, because it would have relieved it of the necessity to divide its forces to oversee the evolution of the embarrassing Polish Question and would have been capable to focus its attention on a solution to the other problem, the Eastern one. This perspective was likely to happen, especially in the conditions of the peace Treaty that Russia had imposed to Turkey, at Adrianople, on September 14th 1829, which ensured the latter's "passivity" towards the Oriental policy of its victor.

These perspectives affected, in particular, Great Britain and France, the secular rivals of Russia in that area, so they tried, using only diplomatic means because of the very complicated international situation at the beginning of the fourth decade of the nineteenth century, to determine Russia to adopt a more conciliatory attitude towards the Polish insurgents.

The rivalries that aggravated the Franco-British relations, especially in Western Europe, prevented the two Powers to adopt a unitary position towards Russia, a fact that allowed the latter to dictate the law in the Kingdom of Poland.
\end{abstract}


A position, in some way singular, towards the Polish Question was adopted by another state, with direct interests in the Baltic sea area and with more specific ones in the Eastern Question. It is the United Kingdom of Sweden and Norway, created in the letter and the spirit of the Swedish-Norwegian Convention from Moss, on August 14th 1814.

Sweden's internal and external political circumstances in which, in 1810, the famous marshal of Napoleon I, Jean Baptiste Sebastien Bernadotte, prince of Pontecorvo, was proclaimed crown prince under the name Karl Johan, King Karl XIV Johan, from 1818, as the creation of the Swedish-Norwegian personal Union, determined the Swedish-Norwegian diplomacy favor the Russian interests in the Polish Question as well as in the Eastern Question. In the Polish Question, the one under our analysis, this was also because the insurrection of November 1830 started in the international conditions mentioned above and due to the fact that the liberal internal opposition to the conservative and absolutist monarchical policy of King Karl XIV Johan was becoming more active and could have constituted a reason for the Norwegians to evade the personal Union, which they did not favor and against which they fought, first through arms then by institutional means.

The forms in which Great Britain, France and Sweden took position in regard to the reprisal of the Polish insurrection of November 1830, very well documented by the diplomatic reports of the British diplomats in St. Petersburg and of the Swedish ones, accredited in Petersburg and in London, which we had the opportunity to consult in the funds of manuscripts of British Library, in London, and those of the National Archives of Sweden, in Stockholm, constitute, in our opinion, a contribution to the knowledge of the history of European diplomacy, on one hand, and to the research of the international relations in the first half of the nineteenth century, on another. This is the reason why we intend to approach them in this study.

All the documents selected from Sveriges Riksarkivet, in Stockholm and cited in these pages are included in the volume X, part I, of the Collection "Europe and the Porte", which is still in manuscript, for this reason we indicated the archive quotations.

\section{Rezumat:}

Declanşarea, la 29 noiembrie 1830, a insurecției poloneze şi evoluția acesteia au reținut atenția puterilor europene, mai mari sau mai mici, datorită atât imprejurărilor politice internaționale in care a debutat şi a evoluat, anume, revoluțiile burghezo-liberale din Franța, Belgia, Germania, Italia, Spania, Portugalia, cât şi implicațiilor pe care era de aşteptat să le antreneze, tocmai datorită acelor imprejurări, asupra raportului de forțe de pe Continent, cât şi a celui din problema orientală. Pentru că, de modalitatea în care avea să fie rezolvată problema poloneză depindea poziția pe care avea să o dobândească Rusia, în amintitele sisteme politice. În primul caz, deoarece, subordonând, în totalitate Regatul Poloniei, a cărui 
individualitate politică, în cadrul sistemului politic şi instituțional al Rusiei, în care îl plasase deciziile "Actului final" al Congresului de pace de la Viena, din 9 iunie 1815, urma să fie abolită de către țar, îi deschidea Imperiului Rus, pe de o parte, calea către consolidarea pozitiiilor sale în zona Mării Baltice, atât politico-strategice, cât şi economice, şi, pe cale de consecință, crearea oportunităților pentru a-şi exercita o influență supărătoare, pentru celelalte puteri europene, în sistemul politic european. Pe de alta, pentru că, nemaifiind obligată să-şi împartă forțele pentru a supraveghea evoluția atât de stânjenitoarei pentru ea, a problemei poloneze, putea să şi le concentreze pentru adjudecarea rezolvării celeilalte probleme, anume cea orientală, $\mathrm{cu}$ tot cortegiul de consecințe negative asupra sistemului politic european, pe de o parte, iar pe de alta, pentru interesele politice, strategice şi economice ale tuturor statelor europene care aveau câte ceva de apărat, unele mai mult, altele mai puțin, în zonele Mediteranei Orientale şi a celei a Mării Negre . Perspectivă ce părea a avea toate şansele de concretizare, mai ales in condițiile în care Tratatul de pace pe care îl dictase Turciei, la Adrianopol, la 14 septembrie 1829, î asigura "pasivitatea" acesteia față de politica orientală a învingătoarei sale. Deosebit de afectate de asemenea perspective s-au dovedit a fi fost, cum era şi firesc, Marea Britanie şi Franța, rivalele seculare ale Rusiei in acele zone, motiv pentru care au încercat, dar numai pe care diplomatică, din cauza foarte complicatei situații internaționale de la începutul celui de al patrulea deceniu al secolului al XIX-lea, să determine Rusia să adopte o poziție mult mai conciliantă faț̆ de insurgenții poloni. Rivalitătile care grevau şi raporturile franco-britanice, mai ales in Europa Apuseană, le-au impiedicat pe cele două puteri să adopte o poziție unitară față de Rusia, fapt ce i-a a permis acesteia să dicteze legea în Regatul Poloniei.

O poziție, oarecum singulară, faț̆ de problema poloneză a fost nevoit să adopte un alt stat, cu interese directe în zona Mării Baltice şi cu altele specifice în problema orientală. Este vorba de Regatul Unit al Suediei şi Norvegiei, creat în litera şi spiritul Convenției suedo-norvegiene, de la Moss, din 14 august 1814. Imprejurările politice, interne şi internaționale ale Suediei, în care a fost proclamat, în anul 1810, prinț moştenitor al tronului suedez, celebrul mareşal al Franței împăratului Napoleon I Bonaparte, Jean Baptiste Sebastien Bernadotte, prinț de Pontecorvo, sub numele de Karl Johan, devenit, din anul 1818, rege al Suediei, sub numele de Karl XIV Johan, ca şi crearea Uniunii personale suedo-norvegiene, îndeosebi, au determinat diplomația Suediei-Norvegiei să menajeze interesele Rusiei in problema poloneză, ca şi în cea orientală. În problema poloneză, in cazul de față, în cea concretă a insurecției din noiembrie 1830, şi pentru faptul că insurecția se declanşase în amintitele condiții internaționale, şi pe fondul activizării opoziției liberale interne față de politica conservatoare şi absolutist-monarhică a regelui Karl XIV Johan şi putea constitui un prilej binevenit pentru norvegieni de a se sustrage Uniunii personale cu Suedia, pe care nu o agreau şi impotriva căreia au luptat, mai întâi, prin forța armelor, apoi, pe cale instituțională. 
Formele în care s-au manifestat luările de poziție ale Marii Britanii, ale Franței şi ale Suediei, cele mai bine documentate de rapoartele diplomaților englezi, acreditaț la Petersburg şi a celolr suedezi, acreditați atât la Petersburg, cât şi la Londra, pe care am avut posibilitatea să le consultăm în fondurile de manuscrise de la British Library, din Londra, şi din cele ale Ahivelor Naționale ale Suediei, din Stockholm, față de reprimarea insurecției poloneze din noiembrie 1830, constituie, după părerea noastră, o contribuție la cunoaşterea istoriei diplomației europene, pe de o parte, iar pe de alta, la cercetarea istoriei relaților internaționale din prima jumătate a secolului al XIX-lea. Iată, aşadar, motivul pentru care ne-am propus să le abordăm in paginile acestui studiu.

Toate documentele selectate din Sveriges Riksarkivet, din Stockholm şi citate în cuprinsul acestor pagini, sunt incluse in vol. X, partea I, al Colecției "Europe and the Porte", aflat, $\hat{\imath} c \bar{a}, \hat{\imath} n$ manuscris; din acest motiv am indicat cotele din arhive.

Keywords: Poland, Russia, Great Britain, France, Sweden, insurrection

In the evening of November 29th 1830 , a small group of conspirators, under the leadership of Piotr Wysocki, attacked, by surprise, the residence from Belvedere, in Warsaw, of the Grand Duke Constantine, the brother of the Tsar Nicolas I and Supreme Commander of the Russian and Polish armies in the Kingdom of Poland, in order to capture him. The attempt failed because the Duke managed to take refuge in time. Unsuccessful was also the other part of the project that of taking the entire Polish army, quartered in Warsaw, out of the barracks. As a result, Piotr Wysocki, accompanied by a group of sub-officers, crossed the entire Warsaw, from South to North, in the Old city, where he managed, with the help of craftsmen and workers in the area, to capture the arsenal of the army. So, during the night and the next day, the population of Warsaw, which received arms, accompanied by several detachments of Polish soldiers who joined the conspirators, managed to capture the capital forcing the Russian army to withdraw from the city.

This is how the Polish insurrection started and become, in short time, an actual Polish-Russian war, carried out throughout Poland and Lithuania and lasted until October 21st 1831, when the last Polish military units surrendered to the Russian army at, la Zamość1. As a consequence, "The Kingdom of Poland was in the hands of Nicolas I, who started a ruthless campaign

\footnotetext{
1 Józef Andrzej Gierowski, Historia Polski 1764-1864, Warszawa 1985, Państwowe Wydawnictwo Naukowe, p. 181 and following. 90
} 
of reprisals. A brutal military occupation began that facilitated the liquidation of all the political features of Poland. The Polish state would maintain itself only by name" (s. n.) $)^{2}$.

The outburst, the evolution and then the repression of the Polish insurrection by Russia provoked a powerful emotion in Central and Western Europe. Along with the outburst of the revolutions in Europe, in 1830, the public opinion in these areas of Europe started to be concerned about the danger that Russia was posing to their security and liberty. The attitude the Tsar Nicolas I adopted towards those events created the conviction that Russia was on a diametrically opposed position to the principals of liberty, humanity and progress, promoted in the West of Europe. Thus "the Russian suppression of the Polish revolution, followed by the destruction of Polish independence, thereafter lifted Nicolas I to the apex of his infamy, as Western Europe saw it" (s. n) ${ }^{3}$. The liberal and democratic spirit in the Western Europe, expressed through genuine literature of several types, attributed to Poland the quality of being "the outpost of the West against the hostility of the Tsar toward revolutionary gains in Western Europe" (s. n)4. More than that even, it was considered that the outburst of the Polish insurrection "had diverted Russian forces from any possible crusade against liberalism in West during most of 1831" (s. n.) $)^{5}$. A free and powerful Poland also had the same meaning of "natural barrier against Tsarist pressure on Europe" in the opinion of some large, popular circles (s. n.) ${ }^{6}$. The speculations on this subject went so far that in the liberal circles of Europe it was considered that in order to be a strong barrier against the expansion of Russia, the territorial boundaries of Poland had to be wide enough for this mission. Besides the fact that it would have pushed Russia thousands of miles, removing it from Central Europe and reducing the number of populations under its domination, ", a Poland extending to the Black Sea would flank or bar Russian access to the Balkans, bringing relief to the decadent Turkish Empire and security in the Straits question" (s. n.) $)^{7}$. However, this role of Poland was seen as a result of a large Western coalition against Russia, liberal circles from some states attributing the role of leaders to France and

\footnotetext{
2 Ibidem, p. 193.

3 Oscar J. Hammen, Free Europe versus Russia, 1830-1854, in "American Slavic and East European Review, Vol. 11 (Feb.), 1952, p. 28.

4 Ibidem.

${ }^{5}$ Ibidem.

${ }^{6}$ Ibidem, p. 33.

${ }^{7}$ Ibidem, p. 34.
} 
Great Britain. However, the conflict of national interests between the European states was a serious impediment to the creation of a force capable to answer to this objective. This was the case of the two Great Powers, although the Belgian Question, triggered in 1830, contributed to an obvious closeness between them ${ }^{8}$. There were enough reasons to prevent them from collaborating in the stopping Russia's advance towards Central and Western Europe and this reality revealed itself when they approached the modalities of solving the Polish Question.

The outburst of a new revolution in Europe, that in Poland, held, as it was expected, the attention of the British diplomacy which tried to find out the causes and estimate its consequences on the European political system, in general, and for the British interest, in particular. It was expected that Russia would use this opportunity to annul the last concessions granted to the Poles by Alexander I and to consolidate its positions in the European political system. That is why the events in Poland were closely followed, even from their debut, by the Ambassador Extraordinary and Plenipotentiary of Great Britain to St. Petersburg, William A'Court, Baron Heytesbury9.

According to his opinion, expressed in a report addressed to Lord George Hamilton Gordon Aberdeen, the head of Foreign Office, on December 10 $10^{\text {th }} 1830$, with the outburst of the Polish insurrection, , another part of social edifice of Europe has begun to crumble" (s. n. $)^{10}$. A revolution which, "whatever be its ultimate result (and what that result will be, can scarcely be doubted, when we look at the Colossal Power to which the Poles are opposed) must inevitable render the unfortunate Country where it has exploded, a scene of present bloodshed, and devastation, which no success can compensate, the realisation (sic!) of no theories, repay" (s. n.) ${ }^{11}$. A prediction that was about to get real.

The British diplomat approached the issue of the Polish insurrection not from the point of view of its national objectives but from the perspective of Great Britain's interests, which, in the international circumstances from the beginning of the fourth decade of the nineteenth century, were aiming at keeping the continental peace. Thus, he considered that "under any other

\footnotetext{
8 Ibidem, p. 33.

${ }_{9}$ Veniamin Ciobanu, Debutul insurectiei poloneze din noiembrie 1830, în viziunea unui diplomat englez (in manuscript).

10 Ibidem.

11 Ibidem.

92
} 
circumstances - in any other times - it would be impossible not to wish well to the Poles, but our great object now is the Peace of Europe" (s. n.) ${ }^{12}$, which meant, no more, no less, that he thought that, in those tensed international circumstances with revolutions taking place in France and Belgium, the Polish insurrection was a serious threat to the continental peace, as long as it could constitute an opportunity for the Great European Powers to try to change the balance of power between them. That is why he thought that "we must not allow our feelings to get to the better of our reason" (s. n. $)^{13}$. This is why he had doubts in regard to the claims presented by the interim government of Poland to Nicolas I, as King of Poland, among which were the guarantee for the Constitution and the return to Poland of its former provinces, Volhynia and Lithuania, annexed by Russia. He considered that "that last of these demands is quite inadmissible" for Russia, and expressed his doubt that the Tsar would grant audience to the Polish delegation, which went to St. Petersburg to present these claims (s. n.) $)^{14}$. At most, as Karl (Carol) Vasilievici Nesselrode, Vice Chancellor and Foreign Minister of Russia, informed him, he would have received in audience the two members of the delegation not as official representatives but "as private Individuals” (s. n.) ${ }^{15}$.

According to the information sent by Magnus Fredrik Ferdinand Björnstierna, Minister of State and Foreign Affairs of Sweden, on December $14^{\text {th }} 1830$, the news about the Polish insurrection reached the capital of Great Britain two days earlier, on December $12^{\text {th }}$, and made already quite "une grande sensation" (s. n.) ${ }^{16}$. It was considered that this event, and not the revolution in Belgium, would configure the next war theater, as long as the Russian and Austrian armies will be sent against the Polish insurrection ${ }^{17}$. The Swedish diplomat made another interesting observation, he noted that "I'Angleterre entière sympathise avec les Polonais à l'exception de quelques "Ultra Toris » qui confondent la question avec celle du Jacobinisme" (s. n.) ${ }^{18}$.

As the news about the evolution of the events in the Kingdom of Poland were multiplying and diversifying, the sympathy of the English

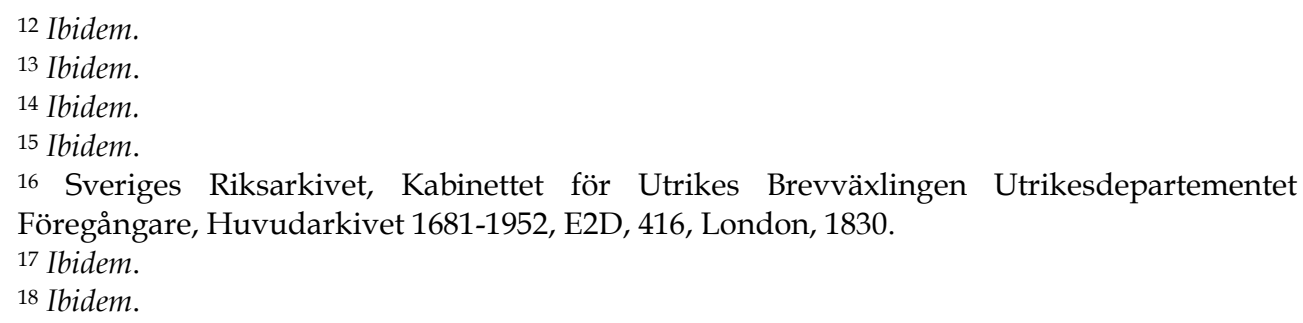


public opinion to the Poles grew and was expressed through press, regardless of its political or ideological orientation. Regarding the parameters in which the Polish insurrection was perceived by the British press, the Swedish diplomat stated that "on n'est point d'après elle une tendance révolutionnaire et Démocratique qui a crée ce mouvement", but "c'est celle du Patriotisme, c'est l'effet d'un peuple généreux, qui veut secouer le joug, que lui a imposé l'étranger par le partage le plus inique dont fait mention l'histoire, qui veut défendre une Constitution et des droits qu'on lui [été arraché?], presqu'aussitôt, qu'on les avait juré, et qui veut rétablir une Nationalité", que des siècles de gloire avait illustré" (s. n.) ${ }^{19}$. Making a parallel between the Belgian and the Polish Questions, the Swedish diplomat considered that a European war was more likely to start because of the latter. Regarding the position that Great Britain could have adopted, he thought that "ce ne sera, qu'à corps défendant, et à la dernière extrémité, qu'Elle prendra part à la conflagration générale" (s. n.) ${ }^{20}$. And as arguments to his point of view, he stated that, on one hand, Great Britain "a trop à faire dans son intérieur, pour s'occuper sérieusement des affaires de l'extérieure", and on another, that "son Commerce gagne trop par la Paix, pour être sacrifié aux chances de la guerre" (s. n.)21. The Ambassador of Great Britain to ST. Petersburg, William A'Court, Baron Heytesbury, also expressed his thought in this regard. Answering to the request of Karl (Carol) Vasilievici Nesselrode, Vice Chancellor and Foreign Minister of Russia, to transmit to his government Russia's desire that Britain should not intervene, in any way, in the Polish Question, the British diplomat assured him that "it was very unlikely $H$. M's Ministers would express any opinion tending to encourage resistance to the Emperor's authority" and that he was "quite certain not a syllable would be uttered in personal disparagement of one of H. M.'s oldest and most faithful Allies" (Russia - n. n.)22. Because, he claimed that, "the Emperor Nicolas's character was too well known, and too much respected in England, to admit of such a supposition"(s. n.) $)^{23}$.

\footnotetext{
19 Ibidem (his report from December 17th 1830).

20 Ibidem his report from January 7th 1831, in Sveriges Riksarkivet, Kabinettet för Utrikes Brevväxlingen Utrikesdepartementet Föregångare, Huvudarkivet 1681-1952, E2D, 417, London, 1831).

21 Ibidem.

22 His report from December 16 th 1830, addressed to the new head of the Foreign Office, Viscount Henry Temple Palmerston, in British Library, Department of the Western Manuscripts, Ms. Add. 41.560, f. 207-208v.

${ }^{23}$ Ibidem.

94
} 
Indeed, on December 31 st 1830, Henry Temple Palmerston exposed, in the Note addressed, at that time, to William A'Court, Baron Keytesbury, the point of view of the British Government, which the British diplomat had to present in St. Petersburg, regarding the way in which the Polish Question would be solved and the continental peace maintained. He was instructed to ensure the Russian government that "the first object of H. M.'s Gov being the maintenance of peace, they are convinced that nothing can tend more surely to the attainment of this object, than a good understanding between Russia and England, and as neither country has any selfish interests to pursue, the motives of their union cannot be misunderstood" (s. n.) ${ }^{24}$. For this purpose, the British government adopted the general principle "of non-interference in the Affairs of other countries, upon which it is their intention to act" (s. n.)25. Regarding the situation in the Kingdom of Poland, the Ambassador had to assure his Russian counterparts that "H. M.'s Govt have learnt with much concern the troubles which have broken out in Poland. Upon this delicate subject they cannot instinct you to make any communication to the Govt of H. I. M. But they cannot contemplate without shuddering the possible consequences of a war of extermination, to be waged between two nations, the one, goaded on by wounded pride and a devotion to their offended Sovereign, - the other excited by alleged grievances and ancient recollections, and desperate by the hopelessness of pardon. It is however much to be wished that during the interval that must claps before the season will admit of any considerable military operations, some arrangement may be effected between the Emperor and his Polish subjects, which may at once maintain the rights of the Sovereign, and remove any just cause of complaint from the Poles: and to such an arrangement, if an opportunity should be afforded in which you might offer your advice without offence to the Russian Govt, you will not fail to lend your best assistance" (s. n.) ${ }^{26}$.

This is how we can explain the fact that the Polish envoy, Marquis Wielopolski, sent to London to obtain the support of the British government, was not received by any British official until January 21 ${ }^{\text {st }} 1831$, as Magnus Fredrik Ferdinand Björnstierna found out ${ }^{27}$.

\footnotetext{
24 British Library, Department of the Western Manuscripts, Ms. Add. 41.560, f. 235-238.

25 Ibidem.

26 Ibidem.

27 His report from January 21st 1831 , in Sveriges Riksarkivet, Kabinettet för Utrikes Brevväxlingen Utrikesdepartementet Föregångare, Huvudarkivet 1681-1952, E2D, 417, London, 1831; instead he thought that "il trouvera une grande sympathie pour Sa cause dans ce
} 
The general enthusiasm provoked in Great Britain by the victories of the insurgents over the Russian armies sent against them in the spring of 1831 had no consequences and did not help the Polish cause in any way. However, as Björnstierna estimate, this state of spirit "ne peut manquer d'influer favorablement sur elle, quand le temps sera venue, de régler cette question sous ses rapports de Politique Européenne" (s. n.) ${ }^{28}$. Because, he explained, "l'opinion dans un Etat Constitutionnel, tel que l'Angleterre est tout. Elle est plus que la Reine, elle est le Roi du Pays, et garde à celui qui oserait la braver" (s. n.) ${ }^{29}$.

The victory of the revolution in France, in July 1830, provoked a serious tension in the international relations. The most affected by the overthrow of the last representative of the Bourbon dynasty from the throne of France, King Charles X, and the election of Louis Philippe as King, proved to be the Tsar Nicolas I. This was because these events violated the principle of the monarchic legitimacy, whose "champion" he was. Instead, as was asserted in the historiography of the problem, Nicolas I, considered this a good opportunity to became "le héros d'une seconde restauration française; son imagination fut surtout sensible à l'éclat dont sa couronne serait environnée s'il s'emparait aux yeux de l'Europe entière du rôle de patron de la légitimité, d'adversaire résolu des idée libérales, et de redresser des torts des peuples" (s. n.) ${ }^{30}$. Thus, he categorically refused to recognize the new authorities in Paris ${ }^{31}$,

Pays-ci, où tous les partis (Tories, Whigs et Radicaux) font des voux sincères pour la Pologne", but which, "cependant finiront, je pense, à n'être que des vœux" (s. n.) (ibidem); on March $24^{\text {th }} 1831$, he transmited to Stockholm the information according to which "j'ai lieu de croire, que le Gouvernement Anglais evera un Consul Général en Pologne dont l'indépendance se trouve garantie par la signature du Traité de Vienne" (s. n.) (ibidem).

${ }^{28}$ His report from April 12 th 1831 , in ibidem.

${ }^{29}$ Ibidem; connoisseur of the state of spirit in the British society, he wanted to take precaution measures regarding his commentaries on the Polish Question, stating that "je supprime ici autant que possible, mes opinions, car là où les passions son en jeu, l'impartialité a le malheur de déplaire des deux côtés. Il vaut donc mieux me taire, au risque de passer pour un inepte" (s. n.) (ibidem). 30 Histoire de la politique extérieure du Gouvernement Français 1830-1848. Avec notes, pieces justificative et documents diplomatiques entièrement inédits. Par M. O. D'Haussonville, Ancien député I, Nouvelle edition, Paris Michel Lévy, Libraires-Éditeurs, 1850, p. 98-99 (following, M.O. D’Haussonville, op. cit.)

31 With the occasion of an audience, which he granted to Paul de Bourgoing, the French Chargé d'Afaires, Nicolas I addressed him with an irritated tone: „avez vous reçu des nouvelles de votre gouvernement, c'est-à-dire de M. le lieutenant général ? (King Louis Philippe - n. n.) car vous savez que je ne reconnais aucun ordre de choses que celui-là, et que je le considère comme seul légal, parce que seul il découle de l'autorité royale légitime...Oui, répétait-il à M. de Bourgoing...oui, tel est ma façon de penser: le principe de la légitimité, voilà ce qui me guidera en toute circonstance; je ne m'en départirai jamais...jamais je ne pourrai approuver ce qui vient de se passer en France" (s. n.) (ibidem, p. 100-101). 
because he was convinced that no other European Power will. His assumption proved, in short time, to be wrong, as the European Powers, including Prussia and Austria, his allies, on whose collaboration the Tsar counted, hastened to regulate their relations with France. So that he had to recognize, officially, the new King, Louis Philippe, and his government, thus Victor Emanuel de Mortemart came back to his post, as Ambassador of France at St. Petersburg, reestablishing France's diplomatic relations with Russia $^{32}$.

The official normalization of the Russo-French relations have relieved the crisis in the international relations, provoked by the events of July 1830, the only issue remaining, in the opinion of Magnus Fredrik Ferdinand Björnstierna, was the Polish Question "qui puisse encore mettre des obstacles au parfait retablissement de la tranquillité" in Europe (s. n.) ${ }^{33}$. Russia refused the offers of British and French mediation in its relation with the Polish insurgents and the Tsar only promised a general pardon, but only "quand une fois la Pologne se sera de nouveau soumise" (s. n.) ${ }^{34}$. However, the Swedish diplomat presumed that, because of "les vîs pacifiques" of the French government, led by Casimir Pierre Perier, as of the similar ones of the British government, chaired by Charles Grey, "après avoir fait ce qu'exigent l'Humanité et la générosité des au-delà, mais reposant sur la majorité de leurs Parlemens respectifs, que régit l'influence de l'opinion, il serrait possible, que cellesci les entraine à des mesures, que je considère contraires à leurs désires" (s. n.) ${ }^{35}$. An attitude that was more desirable as the rumor that a British fleet under the command of Admiral Codington, an "Ultra-libéral dans ses principes”, was about to sail to the Baltic sea, was spreading (s. n.) ${ }^{36}$. Still, the Swedish diplomat had to admit the fact that "rien ne rendrait le Ministère plus populaire qu'une intervention armée en faveur de la Pologne, depuis que celle de la diplomatie a manqué", if "il n'y a qu'une voix la dessus dans toute l'Europe" (s. n) ${ }^{37}$.

\footnotetext{
32 Ibidem, p. 103 and following; „le czar - nota M. O. D'Haussonville - comprit cette nécessité; ce qui lui fut impossible, ce fut de l'accepter de bon grâce. Il lui en coûtait trop d'avoir à revenir complètement sur les maximes qu'il avait, dans le premier moment, professées avec plus d'impétuosité que de réflexion" (s. n.) (ibidem, p. 104).

${ }^{33}$ His report from May 20th 1831 , in Sveriges Riksarkivet, Kabinettet för Utrikes Brevväxlingen Utrikesdepartementet Föregångare, Huvudarkivet 1681-1952, E2D, 417, London, 1831.

34 Ibidem.

35 His report from May 20 th 1831 , in ibidem.

${ }^{36}$ His report from May 31 st 1831, in ibidem.

37 Ibidem; Björnstjerna based his judgments on the fact that "l'Angleterre est sur les meilleurs terms avec la France. Je crois cet accord généralement populaire en Angleterre, et l'être en France aussi
} 
Nevertheless, there was not any reason to believe that a new international crisis would outburst, determined by the Polish Question, opinion shared also by the Ambassador of Russia to London, Khristofor Andreevici Liven, who did not exclude the possibility of such crisis if England would have intervened in the Polish Question ${ }^{38}$.

The events that took place in Western Europe in the second part of 1831 and in the beginning of the following year, determined an obvious tension in the relations between France and Britain. The French expedition in Portugal, the occupation, by the French troupes of Anvers, the military intervention in the Northern Italy, supporting the revolution started there against the Austrian authority and, especially, the way in which the French occupied Ancône, a city on the territory of the Papal States ${ }^{39}$, provoked not only the irritation of the Holy Chair ${ }^{40}$, but also that of the British government, "malgré la bonne intelligence, qui règne dans ce moment entre les deux Gouvernements, et leur sujets respectifs". These French expeditions in Italy were perceived "avec beaucoup de jalousie et de méfiance” in Great Britain (s. n. $)^{41}$. The most accentuated indisposition was provoked by the expedition in

dans les classes moyennant élevées de la Société. Ces différents faits contribueront à faire juger à Votre Excellence de la crise qui peut avoir lieu. Je suis cependant fort loin encore d'affirmer qu'elle doit avoir lieu" (s. n.) (ibidem).

38 On July 22nd 1831, Magnus Frederik Ferdinand Björnstierna informed Count Gustaf Wetterstedt about the fact that "le Prince de Lieven m'a dit avant hier, qu'il n'avait encore êu aucune communication, qui puisse donner lieu à croire que la Grand Bretagne voulût intervenir dans les affaires de la Pologne, que cela pouvait bien arriver d'un jour à l'autre, mais que jusqu'ici, rien ne c'était fait dans ce sens" (s. n.) (ibidem); referring to the news regarding the possibility of British fleet heading to the Baltic sea, Björnstierna, in an annex to a report from July $29^{\text {th }} 1831$, hastened to reassure the Swedish ruling circles, concerned by the possibility that Great Britain would have followed some objectives which could have affected the security of Sweden, stating, in an annex to a report from July $29^{\text {th }} 1831$, that "la parfaite indifférence avec laquelle le Prince de Lieven a pris cet armement dans ses relations avec le Gouvernement Anglais, quoique, comme moi, il n'a pas manqué d'y fixer l'attention de Sa Cour, me sert de guide, d'autant plus que cet armement pouvait être hostile à la Russie, mais ne pouvait jamais être à la Suède" (s. n.) (ibidem).

39 Occupation carried out at night „et sans avis préalable avec toutes les apparences d'une attaque de vive force" (s. n) (M.O. D'Haussonville, op. cit., p. 38; for other details concerning the events mentioned, see ibidem, p. 20 and following; p. 32 and following).

40 Ibidem, p. 38.

41 The report of A. W. Råland, Chargé d'Affaires ad interim of Sweden to London, to Count Gustaf Wetterstedt, on March 9th 1832, in Sveriges Riksarkivet, Kabinettet för Utrikes Brevväxlingen Utrikesdepartementet Föregångare, Huvudarkivet 1681-1952, E2D, 418, London, 1832; the irritation of the British ruling circles was so accentuated that not even the explanations of the French Prime Minister, Casimir Pierre Perier, could not calm the spirits, the problem being a subject of debate in the House of Lords (his report from March 16 ${ }^{\text {th }} 1832$, in ibidem).

98 
Portugal, which the leading circles in Britain considered to be a threat to the commercial interests of Great Britain, because Portugal was an important market for the British industrial products and had strategic importance because it was a "bridgehead" in the Iberian Peninsula. The consequences of that rivalry were felt in Franco-British collaboration in the Polish Question, and France was suspected that it tried to strengthen its position in Europe, a fact considered more dangerous for the British interests than the "solving" of the Polish Question by Russia alone, "une Puissance aussi éloignée” from Western Europe(s. n. $)^{42}$.

However, the British government could not ignore the attachment of the public opinion to the Polish cause. That is why, we believe, that in order to offer it some satisfaction, it tried to determine, using diplomacy, the Tsar to adopt a more conciliatory attitude towards the Polish insurgents, after the conclusion of the military operations against the insurrection, in October 1831.

The issue on the agenda was the intention of the Tsar to impose to the Kingdom of Poland a "constitution" which was considered to be inappropriate to the rights of the Poles. That is why, on November 23rd 1831, Henry John Temple, Viscount Palmerston, Secretary of Foreign Office, mandated the Ambassador of Great Britain to St. Petersburg, William A'Court, Baron Heytesbury, to inform the Tsar on the British point of view regarding a solution for the Polish Question.

Thus, starting from the fact that "the War (against the Polish insurrection - n. n.) being now over, and the authority of the Emperor (Nicolas I - n. n.) as King (of Poland - n. n.) being completely re-established in Poland", the British government considered that "the time is come when His Majesty (King of Great Britain, William IV) feels himself justified, both by his friendship for the Emperor of Russia and by duty resulting from the obligations which he had contracted under the treaty of Vienna ${ }^{43}$, in addressing to His Imperial Majesty, in

42 The report of Magnus Fredrik Ferdinand Björnstierna, from August $26^{\text {th }} 1831$, in ibidem).
43 He was referring to the Peace Treaty of Vienna, concluded on June 9th 1815 ; according to
Art. I of the "Final Act”, "The Duchy of Warsaw, with the exception of the provinces and districts
which are otherwise disposed of by the following Articles is united to the Russian Empire. Il shell be
irrevocably attached to it by its Constitution, and be possessed by His Majesty, the Emperor of all
Russias, his heirs and successors in perpetuity. His Imperial, Majesty reserves to himself to give to this
State, enjoying a distinct administration, the interior improvement which we shall judge proper. He
shall assume with his other titles hat of Czar, King of Poland, agreeable to the form established for the
titles attached to His other possessions" (s. n.) (The Map of Europe by Treaty showing the various
Political land Territorial Changes which have taken place since the general peace of 1814. With 
the most amicable tone, and with the deference which is due to his rights as an independent Sovereign, some observations as to the best mode of re-settling the Kingdom of Poland under the dominion of the Emperor, on principles accordant with those on which its Union with the Imperial Crown of Russia was originally formed, and in such a manner as may be most conducive to its good government and

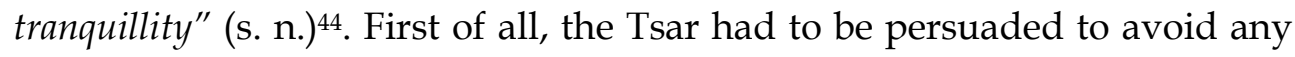
kind of collective reprisals against the insurgents, the British government recommending him to grant "a full and complete Amnesty, from which those persons only should excepted who have been guilty of the crime of assassination"; in such cases, only with the condition that the punishment should be applied "by the ordinary course of justice" (s. n.) ${ }^{45}$. And to convince him about the necessity of such an attitude, his attention was drawn towards a certain reality, honorable for the Poles, which he had to take into account. Namely that "the Poles have displayed, during the late war (between them and Russia n. n.), qualities both of intellect and courage, which prove them capable of being either useful or dangerous subjects, according to the manner in which they may be governed" (s. n) ${ }^{46}$. Therefore, the Tsar's intention to repeal the Constitution granted to the Kingdom of Poland through the "Final Act" of the Peace Treaty from Vienna, meant, in the opinion of the British government, "to reduce that Kingdom, though still nominally possessing a separate existence, to the state and condition of a province, deprived of all rights, and excluded from all the advantages which had been secures to it" (s. n.) ${ }^{47}$. Therefore, the fact that the Poles rebelled and even voted for the removal of the Tsar from Poland's throne, violating, themselves, the letter and the spirit of their Constitution, granted by the Congress of Vienna ${ }^{48}$, could not absolve the Tsar, after his authority was restored in Poland "from his obligation to adhere to that Constitution" (s. n.) ${ }^{49}$. Because, in the opinion of the British government,

\footnotetext{
Numerous Maps and Notes, Vol II, by Edward Herstelet C. B., London 1875, p. 208 and following. (Following, Map of Europe, Vol II).

44 Ibidem, p. 875.

${ }^{45}$ Ibidem, p. 876.

46 Ibidem, p. 877.

47 Ibidem.

48 In compliance with the decisions of the Seim, from January 25th 1831 (Józef Andrzej Gierowski, Historia Polski 1764-1864, Warszawa, 1985, Państwowe Wydawnictwo Naukowe, p. 184.

${ }^{49}$ Map of Europe, Vol. II, p. 879.

100
} 
"wrongs committed by one side are not to be punished by the commission of wrongs on the other" (s. n.) $)^{50}$.

Russia's answer to Great Britain's protest was sent through its Ambassador in London, Khristofor Andreevici Liven. The terms of the Dispatch, dated December $22^{\text {nd }} 1831 /$ January $3^{\text {rd }} 1832$ and signed by the Vice Chancellor Karl (Carol) Robert Vasilievici Nesselrode, left room for no interpretation. First of all, it stated that the Tsar did not commit and did not intend to commit, regarding the manner of approach of the Polish insurrection, no infringement to the Peace Treaty of Vienna. However, he considered this question to be an exclusive internal problem of Russia. That is why, "he is thoroughly determined to admit no Foreign Intervention in questions which concern him exclusively" (s. n.) ${ }^{51}$. Because, in a more close examination of the stipulations regarding Poland, inserted in the "Final Act" of the Vienna Peace treaty, from June $9^{\text {th }} 1815$, the following conclusion would have been reached, "with no other view than to express that the Union of the Kingdom to Russia must be the fundamental principle and the condition of its new existence" (s. n. $)^{52}$. Because the Constitution that Tsar Alexander I granted to the Kingdom of Poland "was not a necessary consequence of the Treaty of Vienna, but a spontaneous act of his sovereign power" (s. n) ${ }^{53}$. The natural conclusion, in the acception of the Russian diplomacy was that ,if the Constitution of Poland had been given in conformity with the Treaty of Vienna, The Contracting Powers would have had the right to take cognizance of it, and to examine whether it answered to the engagements entered into by Russia" (s. n.)54. Or, "none of them claimed this right, nor could they legally do so" (s. n.) 55 . On the contrary, all of them recognized, by ignoring this subject, that "in granting this Constitution to the new subjects the Emperor had followed the dictates of his free will" (s. n.) ${ }^{56}$. These arguments and many others invoked by Vice Chancellor Nesselrode, in the Dispatch, among them the one according to which the Poles themselves annulled the Kingdom's Constitution by their rebellion and the proclamation of the removal of Tsar Nicolas I from Poland's throne ${ }^{57}$, had to

\footnotetext{
50 Ibidem; for the entire document, see ibidem, p. 875 and following.

${ }^{51}$ Ibidem, p. 886.

52 Ibidem.

53 Ibidem.

54 Ibidem.

55 Ibidem.

56 Ibidem.

57 Ibidem.
} 
lead the British government to the conclusion that, as long as the Tsar was making efforts to restore the "moral peace" in Poland and to gradually achieve a "sincere reconciliation" between Poles and Russian, the two "nations" united under the same scepter, any encouragement to those who opposed their legitimate government would have had disastrous consequences. Especially, the Tsar was expecting the British government, in the name of the friendship between the two governments, to favor him and to restrain itself from any intervention in Russia's relations with the Polish Kingdom $^{58}$.

Nicolas I was convinced that maintaining the autonomy of the Kingdom of Poland "would have served only for the outburst of other revolutions" 59. A reason for which he "considered the Constitution as being not mandatory and, in 1832, he issued the so-called Organic Statute, which severely limitated the individuality of the Kingdom, making the first step towards its integration in the Empire" 60.

In order to justify its necessity, in the text of the Statute, dated February $28^{\text {th }} 1832$, there were accused those Poles who, being enemies of the "order" and "legitimate power" of Russia and "dreaming of separation of the two countries subject to our sceptre (Kingdom of Poland and Russia - n. n.), they have abused the benefits of the regeneration of their country, and have used as a means to overthrow his work the privileges and constitutions which they possessed exclusively from his sovereign will" (s. n.) ${ }^{61}$. The consequence was the civil war that brought the country into ruins, a situation rectified by the restoration of peace and the return of the Kingdom under the power of the Tsar, who was

\footnotetext{
58 Ibidem, p. 889-890; for the entire document, see ibidem, p. 885 and following.

59 Józef Andrzej Gierowski, op. cit., p. 218.

60 Ibidem; "the coronation (of the Tsar as King of Poland, at Warsaw - n. n.), the Seim, and the Polish army were abolished. The entire legislative power belonged to the monarch. The State Council and a reduced Administrative were kept for the moment but they depended, in a greater extent, on the Governor. It was decided to keep the Polish language as official language, and the civil and criminal Polish legislation finally granted - but only on paper - civil liberties. In reality, due to the martial status of the Kingdom, the most important decisions were taken by the Governor, a man who conquered back Warsaw (from the Polish insurgents - n. n.), [Ivan] Paskievici-Erevanski, and by the military commanders. Besides, the State Council was formed, mostly, of members recruited from Russia. The Organic Statute was never applied; in exchange, the process of assimilation of the rapports that existed in the Kingdom by the ones in Russia, started" (s. n.) (ibidem, op. cit., p. 218); for the text of the Organic Statute, see Konstytucje Polskie 1791-1821. Wydał Marceli Handelsman. Wydanie trzecie poprawione, Nakładem S.K.I. AKC, Polska Składnia Pomocy Szkolnych, Warszawa, 1922, p. 100 and following.

${ }^{61}$ Map of Europe, Vol. II, p. 891.

102
} 
determined to avoid the outburst of such "tragedies" in the future. At the same time, he expressed his wish "that our subjects of the Kingdom of Poland should enjoy all the advantages necessary to their wellbeing and the prosperity of their country; that the respect for persons and property, liberty of Commerce, and municipal franchise, should be maintained; that they should have a distinct Administration, in conformity with their wants, in such manner as that the Kingdom of Poland may never cease to form an integral part of our Empire, and that they may in future make with the Russians but one nation, one people of brothers" (s. n. $)^{62}$.

However, the promulgation of Statute displeased the British government, which maintained the position according to which the Polish insurrection did not gave to the Tsar the right to annul the Constitution which was granted to the Kingdom by Alexander I and was guaranteed by the "Final Act” of the Congress of Vienna, especially because Britain was among the Powers which signed it.

In consequence, at the end of June 1832, it decided to send Lord Durham to St. Petersburg, with the mission, as A. M. Röland thought, "d'obtenir du Gouvernement Impérial quelques concessions en faveur de la Pologne" (s. n. $)^{63}$.

The instruction given to Lord Durham, signed by Henry John Palmerston, on July $8^{\text {th }} 1832$, underlined the desire of British government to avoid any military conflict with Russia over the Polish Question. His mission would have been successful only if the four Great Powers, meaning Great Britain, France, Austria and Prussia, would have acted in the same manner. The reality was completely different, Austria and Prussia were supported Russia's point of view regarding the interpretation of the stipulations referring to Poland in the "Final Act" of the Peace Treaty of Vienna. The only Powers which "stood their ground" were Britain and France, but they could succeed only by arms, a possibility that was out of the question. This is why Lord Durham had to approach the problem with "delicacy" and "precaution"64. However, the emissary had to persuade his counterparts to understand the fact that the British government did not approve to the

\footnotetext{
62 Ibidem, p. 892.

${ }^{63}$ His report from June 29th 1832 , in Sveriges Riksarkivet, Kabinettet för Utrikes Brevväxlingen Utrikesdepartementet Föregångare, Huvudarkivet 1681-1952, E2D, 418, London, 1832; according to his information, the Polish Question was the subject of fierce debate in the House of Commons, in the evening of June $28^{\text {th }} 1832$ (ibidem).

${ }^{64}$ Map of Europe, Vol. II, p. 900-901.
} 
modification of the Polish Constitution and to other measures undertaken already or pending. Among those, "the abolition of the Polish Colors; the introduction of the Russian Language into public acts; the removal to Russia of the National Library, and public collections containing bequests made by individuals upon specific condition that they never should be taken out of the Kingdom of Poland; the suppression of Schools and other establishments for public instruction; the removal of a great number of Children to Russia on the pretence of educating them at the public expense; the transportation of whole families to the interior of Russia; the extent and severity of the military Conscription; the large introduction of Russians into the public employments in Poland; the interference with the national Church" - all being symptoms "of a deliberate intention to obliterate the political nationality of Poland, and gradually convert it into a Russia province" (s. n.) ${ }^{65}$. Lord Durham was instructed to verify if all these abuses were true, and if they were he had to use this opportunity to urge the Russian government, but "with the earnestness, and the same time with the freedom of a sincere friend, to adopt a milder and juster system", highlighting the fact that the British government justified its right to intervene through the stipulations of the Treaty of Vienna (s. n. ${ }^{66}$. In the end of these instructions, he was warned to always have in mind Great Britain's interest "to cultivate and increase, if possible, the friendly relations now so happily subsisting between this country and Russia", at the same time, having to assure Tsar Nicolas I "of sincere and cordial friendship which His Majesty entertains for His Imperial Majesty, and of declaring His Majesty's desire to maintain, and, if possible, to draw closer the bond of alliance which connect two Powers whose union must have so salutary an effect in preserving the Peace of the World" (s. n) ${ }^{67}$.

An intervention undertaken under such auspices was bound from the start to fail. The signs were obvious, even from the moment it was designed. Thus, on the occasion of the negotiations that the Russian Ambassador to London, Khristofor Andreevici Liven, held with Charles Grey, head of the British government, the fact that Lord Durham's mission

\footnotetext{
65 Ibidem, p. 901-902; in connection with this last intention of Russia, it was stated that this kind of project was unachievable because it was impossible "to change 4,000,000 of Poles so entirely as to impart to them the character of Russians in an attempt for the success of which it would be difficult to assign a limit, either of time or perseverance"; on the contrary, such an attempt "would lead to a severe and continual exertion of arbitrary power, which would create a strong and general feeling against Russia, and must be regarded as a decided violation of the engagements contracted by Russia at Vienna in 1815" (s. n. ) (ibidem, p. 902).

66 Ibidem.

67 Ibidem.
}

104 
would not have the results expected was obvious. Because, the Russian diplomat "s'est prononcé, dit-on, de la manière la plus distincte en exprimant ses craintes de l'accueil peu satisfaisant auquel pourrait s'exposer un négociateur chargé d'une pareille mission, et sa conviction de la ferme résolution de l'Empereur (Nicolas I - n. n.) de ne changer en rien la ligne qu'il s'est tracé à l'égard des affaires de la Pologne" (s. n.) ${ }^{68}$. Then, as A. W. Röland, Sweden's Chargé d'Affaires ad interim to London, thought, even if Great Britain would have justified its right to intervene in the Polish Question, invoking it quality as guarantor of the Polish Constitution, stipulated in the "Final Act” of the Congress of Vienna, his demarches were late. It would have been successful if it had been undertaken several months before, more precisely at the end of the insurrection, "cause primitive des mesures de rigueurs, dont croit devoir se plaindre maintenant sur la cessation desquelles il est dit que Lord Durham est chargé d'insister de la manière la plus prononcée" (s. n.) ${ }^{69}$. And, indeed, Lord Durham completed his mission, assuring Vice Chancellor Karl (Carol) Robert Vasilievici Nesselrode "que c'était là une discussion terminée des le mois de Février entre le Comte (Nesselrode - n. n.) et lord Heytesbury (s. n.) $)^{70}$. Thus, he was complying to one of the indication inserted in his instructions, according to which he had to refer, during the negotiations, "to the representations already made upon this subject by Her Majesty's Ambassador at the Court of St. Petersburg (William A'Court, Baron Heytesbury - n. n.), but you will not press this matter in such a manner as, without producing any benefit to Poland, would incur the hazard of increasing the difficulties already existing on the various subjects to which your attention has been called in this dispatch" (s. n.) ${ }^{71}$.

68 The dispatch of A. W. Röland, from July $3^{\text {rd }}$ 1832, in Sveriges Riksarkivet, Kabinettet för Utrikes Brevväxlingen Utrikesdepartementet Föregångare, Huvudarkivet 1681-1952, E2D, 418, London, 1832.

${ }^{69} \mathrm{Ibidem}$; the Swedish diplomat also suggested that there was another cause which could have determined the failure of Lord Durham's mission: "le caractère hautain et peu pliant du négociateur, joint à ses principes trop connus d'un libéralisme presque outré, semble aussi être d'un fâcheux augure pour la réussite de sa mission"; plus, "quoique homme de talent, on craint que Lord Durham ne possède point les qualité nécessaires pour entamer avec quelque succès un négociation d'une nature aussi délicate" (s. n.) (ibidem).

70 The report of Nils Gustaf Pelmtierna, to the Chancellor of the Swedish Royal Court, David Schulzenheim, from August 18 ${ }^{\text {th }} / 6^{\text {th }} 1832$, in Sveriges Riksarkivet, Kabinettet för Utrikes Brevväxlingen Utrikesdepartementet Föregångare, Huvudarkivet 1681-1952, E2D, 703, Petersburg, 1832, jan.-16/10.

71 Map of Europe, Vol. II, p. 901; referring to these instructions, Nils Fredrik Palmstierna, Sweden's Chargé d'Affaires to St. Petersburg, noted, in the report addressed to Count Gustaf Wetterstedt, his Foreign Minister, that "les dernières instructions de l'Ambassadeur Anglais relativement aux affaires de la Pologne, n'impliquent point l'adhésion de son Gouvernement aux vues 
The revolutionary origins and the circumstances of the establishment of the July monarchy in France provoked a great anxiety in Europe ${ }^{72}$. However, some European states rapidly recognized the political regime created by the revolution of July. First of those states was Great Britain, with the condition that France respects the existing international treaties and to try not to provoke new turmoil in Europe ${ }^{73}$. Austria and Prussia followed, and eventually Russia, which „annonçaient, en termes tout aussi formels, leur résolution de maintenir le statu quo territorial de l'Europe, tel qu'il avait été réglé par le congrès de Vienne, et de ne souffrir aucune tentative de propagande révolutionnaire" (s. n.) $)^{74}$.

Confronted with such serious difficulties, the new French government did not hesitate to adopt one of those principles "qui décident de

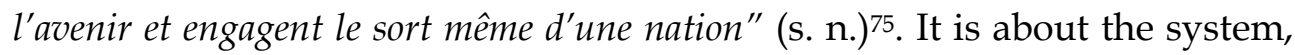
later called "de non intervention"(s. n.), stated by the Foreign Minister, Louis, Conte Molé, which, in those circumstances, corresponded in the highest grade to the needs of France but which provoked a strong irritation to Austria , Prussia and Russia. Because, the new principle of the French foreign policy not only it did not guaranteed, in those European circumstances, their interests, on the contrary, "il devait finir par tourner contre elles" (s. n.) ${ }^{76}$.

que la Russie avait annoncées, concernant l'organisation de ce pays. Il parait néanmoins qu'on ne proteste qu'à peu près pour la forme, sans amertume, et probablement pas avec l'intention d'insister" (s. n.) (Sveriges Riksarkivet, Kabinettet för Utrikes Brevväxlingen Utrikesdepartementet Föregångare, Huvudarkivet 1681-1952, E2D, 703, Petersburg, 1832, jan.-16/10).

72 „Les événemens de Paris - noted Magnus Fredrik Ferdinand Björnstierna in his report to Count Gustaf Wettterstedt, on December $24^{\text {th }} 1830$ - me confirm dans l'opinion, que le régim de Napoleon est le seul adaptable au Caractère Francais, qui ne connaitra la liberté sans tomber dans la licence"; however, he accepted the fact that ",bien d'autre Peuples sont dans le même cas"; still, he noticed that, "il y a cependant d'honorables exceptions, et l'on ne peut nier que l'Angleterre n'en fasse une" (s. n.) (Sveriges Riksarkivet, Kabinettet för Utrikes Brevväxlingen Utrikesdepartementet Föregångare, Huvudarkivet 1681-1952, E2D, 416, London, 1830).

73 M. O. D'Haussonville, op. cit., p. 16.

74 Ibidem, p. 17.

75 Ibidem.

76 Ibidem, p. 17-18; Prince Klemens Wenzel Nepomuk Lothar von Metternich Winneberg zu Beilstein, Foreign Minister of Austria, proved to be the most convinced of this danger; according to the information sent to Paris, in September 1830, by the French Chargé d'Affaires to Vienna, he strongly protested "contre la prétention étrange du gouvernement francais d'introduire, pour sa convenance, un nouveau droit des gens don ton n'avait jusque-là jamais entendu parler, et qui été purement et simplement le renversement de toutes les règles qui avaient jusqu'alors présidé à la politique des états européens" (s. n.) (ibidem, p. 10-11).

106 
This principle proved to be quite efficient in solving the Belgian Question but, in the same time harmful, when applied to the Polish Question. The idea of a military intervention in favor of the Polish insurgents being out of the question, due of the principle mentioned above ${ }^{77}$, the new French government started a sustained diplomatic campaign, in order to obtain the collaboration of the European Powers directly interested in this question. The demarches undertook in Vienna by the French cabinet, "pour s'assurer le concours moral de l'Autriche dans un but de paix et d'humanité" (s. $\mathrm{n}$. ${ }^{78}$, were undermined by Austria's interests in the Polish Question, on one hand, and by "la crainte de blesser les susceptibilités de l'empereur de Russie”, on another (s. n.) $)^{79}$. Thus, the efforts of the French government "pour entrener le cabinet de Vienne à une intervention pacifique, soit pendant la lutte, afin d'arrêter l'effusion du sang, soit plus tard, quand vint l'issu fatale, afin de prévenir l'atteinte dont les traités étaient menacés (the Treaties from Vienna, in 1815 - n. n.), ne furent malheureusement accueillis que par des réponses évasives, ou stériles protestations" (s. n.) ${ }^{80}$. The same fate was shared by the attempts to determine Prussia to, at least, restrain from giving Russia any direct support in the suppression of the Polish insurrection ${ }^{81}$.

77 Although Magnus Fredrik Ferdinand Björnstiera, in a report sent to Count Gustaf Wetterstedt, on December $21^{\text {st }} 1830$, expressed his conviction „ que la France étendra Son bouclier protecteur sur l'indépendance de la Pologne et ne permettra point à l'Autriche ni à la Prusse d'intervenir dans la question Russo-Polonaise sans être attaquées dans les Provinceda du Rhin ou dans celles de l'Italie qui sont prètes l'une et l'autre à se soulever à la voix de la France. Que la Pologne se défende jusqu'à l'ouverture de la Navigation et Elle est sauvée" (he was referring to the reopening of the Baltic sea for navigation, after the passing of winter, in order to receive help $-n$. n.) (s. n.) (Sveriges Riksarkivet, Kabinettet för Utrikes Brevväxlingen Utrikesdepartementet Föregångare, Huvudarkivet 1681-1952, E2D, 416, London, 1830).

78 Ibidem, 28.

${ }^{79}$ Ibidem, p. 28-29.

80 Ibidem, p. 30.

81 Ibidem, p. 31; December 17th 1830, Magnus Fredrik Ferdinand Björnstiera informed Count Gustaf Wetterstedt that, according to some news, inserted in "Journal de Commerce", on December $15^{\text {th }}$, the French Ambassadors accredited to Vienna, Berlin and London were authorized to declare "que si la Prusse ou l'Autriche se joignent aux Russes pour réduire la Pologne, la France considera une telle intervention, comme déclaration de guerre contre Elle" (s. n.); a news that, in our opinion, has to be interpretated, as an expression of the French public opinion and of the republican opposition from the French Parliament and not as a real intent of the government; in this regard, the information, inserted in the same report catches our attention, according to this „le Général La Fayet (Maurice Joseph Paul Yves Roch Gilbert de Motier, Marquis de La Fayet, known under the name Lafayette, commander of the Nationa Guard, appointed in this dignity by King Louis Philippe, the leader of the republican opposition from the French Parliament-n. n.) a déjà porté le Toast de l'indépendance Polonaise, à un repas de Gardes Nationales" (s. n.) (Sveriges Riksarkivet, Kabinettet för Utrikes Brevväxlingen 
As far as it concerned it, Russia constantly refused the French mediation offers, even banning the insertion of a speech of the French King on this subject, in the Russian press. Or, the reason invoked by Vice Chancellor Karl (Carol) Robert Vasilievici Nesselrode, to justify this measure was "que Nous ne voulons point autoriser l'opinion que nous avons admis les bons offices, dont il est fait mention dans son discours" (s. n.) ${ }^{82}$. After he declined all the French attempts to offer mediation in favor of the Poles ${ }^{83}$, on January $3^{\text {rd }}$ 1832, Nicolas I incriminated "this deplorable system which the Propaganda has made France adopt, and which has been imitated in other countries, has already produced the most disastrous results in the Kingdom of Poland" (s. n.) $)^{84}$.

So, the French government, starting from 1830, made only diplomatic undertakings in favor of the Polish insurgents, but "ne les avait point encouragés dans leur noble mais périlleuse entreprise" (s. n.) ${ }^{85}$. The same policy line was adopted by the governments that followed, especially that led by the banker Casimir Pierre Périer, which came to power on March 13 $3^{\text {th }} 1831$, and whose program of government was defined as being "on the middle line: in domestic policy, order without sacrificing liberty, in foreign policy, peace without damaging the honor" of France (s. n.) ${ }^{86}$. And the one who strictly applied this policy in the Polish Question, was Horace François Sebastiani de la Porta. Even from the beginning of the Polish insurrection, in November 1830, Sebastiani refused to respond to the requests of support came from the Polish insurgents, arguing that he did not want to provoke the Tsar's "wrath".

\footnotetext{
Utrikesdepartementet Föregångare, Huvudarkivet 1681-1952, E2D, 416, London, 1830), also another, comeing from the same diplomat, which, on January 11th 1831 , informed Count Gustaf Wetterstedt that „le Général Lamarque (Jean Maximilen Lamarque, a supporter of the insurrections from Poland and Italy $-\mathrm{n}, \mathrm{n}$.) avait annoncé pour aujourd'hui une motion dans la Chambre des Deputés en faveur des Polognés, qui sera vivement soutenue par l'extrème gauche" (Sveriges Riksarkivet, Kabinettet för Utrikes Brevväxlingen Utrikesdepartementet Föregångare, Huvudarkivet 1681-1952, E2D, 417, London, 1831).

82 The report of Nils Fredrik Palmstierna to Baron David Schulzenheim, August $13^{\text {th }} / 1^{\text {st }} 1831$, in Sveriges Riksarkivet, Kabinettet för Utrikes Brevväxlingen Utrikesdepartementet Föregångare, Huvudarkivet 1681-1952, E2D, 701, Petersburg, 1831, iuli-dec.

83 In November 1831, for example, in the Dispatch sent to Carl Osipovici Pozzo di Borgo, the Russian Ambassador to Paris, it was mentioned that „le Cabinet Impérial ne pourrait plus recevoir de la part du Cabinet Français aucun ouverture relativement au Royaume de Pologne ou aux rebelles Polonais" (s. n.) (Riksarkivet, Kabinettet för Utrikes Brevväxlingen Utrikesdepartementet Föregångare, Huvudarkivet 1681-1952, E2D, 703, Petersburg, 1832)

84 Mape of Europe, Vol. II, p. 889.

85 M. O. D'Haussonville, op. cit., p. 31.

86 Istoria Franței. Coordonatori Jean Carpentier, François Lebrun. Preface by Jacques Golf, Traducere Aurelia Stoica, Institutul European, Iaşi, 2001, p. 281.

108
} 
However, he promised to the Poles he would try to mediate between them and Russia. An attempt that had a total fail in January 1831, as it was to expect. Then, when the Russian armies occupied Warsaw, on September $8^{\text {th }}$ 1831, he communicated to the Chamber of Deputies "la chute de l'héroique Pologne, par ces mémorables paroles: l'ordre règne à Varsovie" (s. n.) ${ }^{87}$. Touched by this "goodwill” sign, from the high French dignitary, Tsar Nicolas I hastened to restore diplomatic relations with France, the Duke of Trévise taking the post of Ambassador of France to St. Petersburg. Thus, the predictions of William A'Court, Baron Keytesbury, Ambassador of Great Britain to St. Petersburg, according to which, even if it wanted to respect the peaceful assurances give to Russia, France „may not have the power, to resist the fresh impulse that will be given by such circumstances to the faction, whose interest live in disorder and confusion", were refuted (s. n.) $)^{88}$.

The international reaction to the suppression of the Polish insurrection by Russia, in November 1830, were under the auspices of the confusion of the Polish cause with the "insurrectional" principle, which "leur avait mis les armes à la mains" (s. n.) ${ }^{89}$. This was, actually, the interpretation given to the events by Austria90, but also by Sweden.

The United Kingdom of Sweden and Norway, with direct interests in the Baltic sea area and with more specific ones in the Eastern question, adopted a position, in some ways, singular, towards the Polish Question. Sweden's internal and external political circumstances in which, in 1810, the famous marshal of Napoleon I, Jean Baptiste Sebastien Bernadotte, was

\footnotetext{
87 Biographie des célébtités militaires des amées de terre et de mer de 1789 à 1850. Par M. C. Mullié, Tome seconde, Paris, f. a., p. 530.

88 Veniamin Ciobanu, op. cit.

${ }^{89}$ M. O. D'Haussonville, op. cit., p. 29.

90 According to an account of the French Ambassador in Vienna, Nicolas Joseph Maison, Metternich would have said to him: „Croit-on que, comme homme, je puisse être insensible à la vue de tant de courage? Et pense-t-on que, comme ministre, je n'aimerais mieux avoir pour voisin une Pologne toujours bienveillante et toujours amie, qu'une Russie toujours envieuse et toujours envahissante? (s. n.) (ibidem); in this regard, there is also an information sent to Stockholm by Nils Fredrik Palmstierna, on August $13^{\text {th }} / 1^{\text {st }} 1831$, according to which he found out, from the first moment when the Court of Austria found out about the French demarches aiming to determine the Tsar to accept their mediation in the war with the Polish insurgents, "a fait dit ici (at St. Petersburg - n. n.) qu'elle espérait bien de voir rejeter cette offre de médiation, l'exemple de la Belgique (he was referring to the revolution from Belgia, started on August 25 th $1830-n$. n.) ayant abondamment démontré où l'on arrive par les interventions du genre" (s. n.) (Riksarkivet, Kabinettet för Utrikes Brevväxlingen Utrikesdepartementet Föregångare, Huvudarkivet 1681-1952, E2D, 701, Petersburg, 1831, iuli-dec.)
} 
proclaimed crown prince, prince of Pontecorvo, under the name Karl Johan, King Karl XIV Johan, from 1818, as the creation of the Swedish-Norwegian personal Union, determined the Swedish-Norwegian diplomacy coddle the Russian interests in the Polish Question as well as in the Eastern Question. In the Polish Question, the one under our analysis, this was also because the insurrection of November 1830 started in the international conditions mentioned above and due to the fact that the liberal internal opposition to the conservative and absolutist monarchical policy of King Karl XIV Johan was becoming more active.

For, although he had its social origins in the middle class of the French society, and owed his entire career to the French Revolution of 1789, he accepted with great difficulty restrictions imposed to the monarchic power by the Constitution of 1809, which replaced the absolute monarchy with a constitutional one, according to which the King could not exert his power "qu'avec la caution de conseillers responsables"91. During his entire reign (1818-1844), his political conceptions were highly conservative, for the application of which he used the services of a protégée, the aristocrat Magnus Brahe, who become his almighty personal counselor ${ }^{22}$. As a consequence, in the '30s, all the Parliament's (Riksdag) sessions were performed under the sign of violent confrontations with the King's government and his private collaborators. And, between its sessions, the King "combattait une presse libérale sans cesse plus nombreause et bruyant en interdisant des journaux et en faisant des procès à leurs éditeurs responsables" (s. n. $)^{93}$. In those circumstances, more dangerous than the possibility that the Polish insurrection would sharpen the liberal opposition was the fact that could have constituted a reason for the Norwegians to evade the personal Union, which they did not favor and against which they fought, first through arms then through institutional ways.

This is why the Swedish diplomacy paid close attention to the events in the Kingdom of Poland and in Lithuania, even from their beginning ${ }^{94}$, its

\footnotetext{
91 Jörgen Weibul, La Suède. Un aperçu historique, Institut suédois, 1993, f.l., p. 92.

92 Thus, him must have been addressed by "non seulement le Conseil, mais aussi le prince Oscar, fils unique de Charles-Jean, lorsqu'ils voulaient avoir l'oreille du roi" (s. n.) (ibidem).

93 Ibidem, p. 93.

$94 \mathrm{See}$, in this regard, Veniamin Ciobanu, Informatii din surse diplomatice suedeze privind ecoul în Rusia al declanşării insurecției poloneze din noiembrie 1830, in „Romanoslavica” New series, vol. XLVI, nr 3, University of Bucharest Publishing House , 2010, p. 5-18; idem, Data pertaining to the outbreak of the Lithuanian insurection (25 March 1831, retrived fron Swedish diplomatic sources, 110
} 
representatives, in St. Petersburg or London, manifested sometimes, on personal basis, and only for the use of Stockholm decision makers, a certain degree of sympathy and understanding towards the insurgents, without hesitating, at the same time, to reveal their weak points ${ }^{95}$. Officially, the Swedish government adopted a position appropriate to its line of policy, mentioned above. Thus, the Foreign Minister, Count Gustaf Wetterstedt, mandated Nils Fredrik Palmstierna to ensure the Russian Vice Chancellor and Foreign Minister, Karl (Carol) Robert Vasilievici Nesselrode "de l'impression pénible que le Roi (Karl XIV Johan - n. n.) a eprouvé en apprenant une nouvelle aussi chagriant pour l'Empereur (Nicolas I - n. n.), que l'était celle de la révolte en Pologne", mission which he accomplished without any delay (s. $\mathrm{n} .{ }^{96}$. At the same time, the Swedish government assured its Russia counterpart that the King did not intend to grant audience to an emissary of the Polish insurgents who would have asked for support from Sweden ${ }^{97}$, and that the King will always keep the same attitude of loyalty to the Tsar and, of course to its interests in Poland ${ }^{98}$. Besides, as Nils Fredrik Palmstierna noticed, in the ruling circles of the Russian Empire there was no doubt about the feelings of the Swedish King towards the Tsar "ni sur la constant loyauté d'une politique, dont cette qualité forme la base" (s. n.)99.

The order of the Foreign Minister to refuse the request of Marquis Wielopolski of a Swedish passport for a Polish emissary, sent to Magnus Fredrik Ferdinand Björnstiera, was following the line of the same policy. The

in „Revista Română de Studii Baltice şi Nordice (The Romanian Journal for Baltic and Nordic Studies) ; Vol. 3, Issue 1 (2011), Târgovişte, p. 65-86.

95 "C'est un coup desespéré - thought Magnus Fredrik Ferdinand Björnstiera, in a report adessed to Count Gustaf Wetterstedt, on December 14th 1830 , - que celui qu'ont joué les Polonais. Sans frontières, sans forteresse, sans argentt, cernés dde tous côtés, par les copartageans (meaning Austria, Prussia and Russia, the three European Powers that made those divisions of Poland, in 1772, 1793 and 1795 - n. n.), sans ports de Mère, et sans communication quelconque avec des Puissances interessées à leur restauration ce ne serait, que par les efforts les plus heroiques, et par l'union la plus parfaite, que pourrait se retablir cet ancien boulevard de l'Europe"; totuşi, nu omitea el să adauge că "je crois les Polonais capables de la première de ces conditions, mais non de l'autre"; because, "l'histoire en fait preuve. C'est leur désiunion, que toujour les a perdîu" (s. n.) (Sveriges Riksarkivet, Kabinettet för Utrikes Brevväxlingen Utrikesdepartementet Föregångare, Huvudarkivet 1681-1952, E2D, 416, London, 1830).

96 See his report from January $8^{\text {th }} 1831$ /December $27^{\text {th }} 1830$, in Riksarkivet, Kabinettet för Utrikes Brevväxlingen Utrikesdepartementet Föregångare, Huvudarkivet 1681-1952, E2D, 701, Petersburg, 1831, Jan-iuni.

${ }^{97}$ His report from February $15^{\text {th }} / 3^{\text {rd }} 1831$, in ibidem.

${ }^{98}$ His report from August $13^{\text {th }} / 1^{\text {st }} 1831$, in ibidem, Iuli-dec.

${ }^{99}$ His report to Count Gustaf Wetterstedt, from January $29^{\text {th }} / 17^{\text {th }} 1831$, in ibidem. 
Swedish diplomat not only hastened to comply with the order but also advised Wielopolski to give up any undertaking in this way, because he knew the position on the Swedish court towards the Polish insurrection ${ }^{100}$.

Noteworthy is the fact that the opinions of the Swedish diplomats, who approached problems concerning the Polish insurrection in their reports, oscillated between its justification and, from certain point of views, its reprobation, also expressing some reserves and critics towards the measures adopted by the Tsar for its suppression but also approving some. Very conclusive, from this point of view, are the opinions of Nils Fredrik Palmstierna, an informed observer and analyst of those events. In his opinion, "dans l'affaire de Pologne, comme dans la plupart des affaires semblable, l'histoire devra écouter les deux parties pour asseoir un jour le jugement, qu'elle prononce sans appel. Elle repoussera les déclamations banales des anarchistes, comme vaines et ne prouvant rien; mais elle s'occupera à récueillir les faits vérifiés. Elle prononcera, selon toute apparence, que si rien ne saurait justifier ni la rébellion même, ni les actes atroces, qui en signalèrent les premiers momens, il y a néanmoins des faits, qui suffisent pour expliquer la première. Si l'une des deux parties est condamnée, comme elle ne manquera de l'être, l'autre ne sera pas absonte; l'Empereur, personnellement, sera peut-être le seul qui, aux yeux de l'impartialité, Se trouvera excusé" (s. n.) ${ }^{101}$. He thought that the insurrection could have been avoided, or, at least, would have had a less fateful evolution, if the Polish nobility would have known its real interests. This did not happen because the biggest part of it was deceived ,aux illusion du moment, nouris par les phrases intolérables des philosophes folliculaires du pavé de Paris, dont la présomptieuse igneurance et dont souvant l'insigne mauvaise foi prêche avec impudeur les sotisses les plus absurdes, comme s'il c'étaient des axiomes" (s. n.) ${ }^{102}$.

More extensive are his consideration formulated on a different occasion. Commenting the measures adopted by Tsar Nicolas I, after the defeat of the insurrection, in November 1830, he analyzed them from a double perspective: on one hand, as coercive measure and on the other as

\footnotetext{
100 His report from March 24th 1831 , to Count Gustaf Wetterstedt, in Sveriges Riksarkivet, Kabinettet för Utrikes Brevväxlingen Utrikesdepartementet Föregångare, Huvudarkivet 1681-1952, E2D, 417, London, 1831; on this occasion, he solicitated instructions in order to know how to act, in the future, in similar cases (ibidem).

101 See his report to Gustaf Wetterstedt, from February 9th/January 28th 1831, in Sveriges Riksarkivet, Kabinettet för Utrikes Brevväxlingen Utrikesdepartementet Föregångare, Huvudarkivet 1681-1952, E2D, 702, Petersburg, 1831, Jan.-Juni.

102 Ibidem.
}

112 
concessions made to the Poles; concerning those from the first category, he also presented them in a double perspective: apparently rigorous, if they were put in connection with the fact that the offenses of the Poles were committed "dans le sens de liberalism", especially that the rebellion had its antecedents in "le souvenir de grandes injures politiques dont cette nation a été victime depuis 1772"; on another hand, he granted Tsar Nicolas I mitigating circumstances; regarding the new political organization of the Kingdom of Poland that was expected, he considered that it "ne lui laisse que l'ombre d'une existence politique à parte", and, among the motivation of that state of things, he underlined, especially, the importance of a direct and unlimited control of Russia over the Kingdom of Poland, from the perspective of the achievement of its objectives in continental policy and in the Eastern Question, as long as, without that control „elle devrait renoncer en même tems à la prépondérence Européenne qu'elle n'exerce à ce degréque depuis qu'elle possède la Pologne; même à Constantinople elle ne dicterait plus la loi"; he also accused a series of other measures adopted by the Tsar, which had no justification and which "parraissent se faire comme exprès pour humilier et pour aigrir, sans qu'il en résult une nouvelle force pour le Gouvernement" (Russian - n. n.), ni une garantie additionelle contre les révoltés"; and among the possible causes that determined the adoption of those measures, he indicated the fact that "l'on veut faire vivement sentir, jusque dans les choses minimes, que désormais il n'est pas question de nationalité et faire disparaitre tout ce qui peut la rappeller. Peut-être croirat-on que de cette manière la résignation, pour être plus complète, n'en sera que plus facile et qu'insensiblememnt les idées se modifieront par l'habitude"; also, he thought that the effects of the insurrection could have been perceived differently by the provinces; at the same time, Nils Fredrik Palmstierna signaled the persistence of a strong state of tension which could have triggered, at any moment, new and serious disturbances, including in territories annexed by Austria and Prussia, his conviction was that Poland „sera toujours un élément dissolutif du systême Européenne, jusqu'à l'époque où l'une et l'autre seront reconstruits sur des nouvelles bases"103.

Therefore, the Polish insurrection of November 1830 started during a very tensed international situation and was one of the most remarkable political and military events of the beginning of the fourth decade of the

103 See his report from May 26 $6^{\text {th }} / 14^{\text {th }} 1832$, in Sveriges Riksarkivet, Kabinettet för Utrikes Brevväxlingen Utrikesdepartementet Föregångare, Huvudarkivet 1681-1952, E2D, 703, Petersbug, 1832. 
nineteenth century. Due to the circumstances in which it started and because of the possibility of provoking a new configuration of the political map of Europe, the event caught the attention of the Great Powers of Europe. However, their attitudes towards the insurrection were determined by reasons deriving from their particular interests, which, at that time were towards maintaining the peace in Europe. Thus, Tsar Nicolas I could suppress the Polish insurrection with his own forces, on one hand, because he managed to impose the idea that the turmoil in the Kingdom of Poland was an internal question of the Russian Empire, and on another "because at that moment the Polish cause did not became a international question" (s. n.) ${ }^{104}$.

Translated by Cosmin Mihuț.

104 Leonid Boicu, op. cit., p. 490. 